UNIVERSIDADE DE SÃO PAULO

FACULDADE DE FILOSOFIA, LETRAS E CIÊNCIAS HUMANAS

DEPARTAMENTO DE LIGUÍSTICA

PROGRAMA DE PÓS-GRADUAÇÃO EM LINGUÍSTICA

MARCO ANTONIO MARINELLI FILHO

Por uma fenomenologia da língua e do signo linguístico

Versão corrigida

São Paulo 
MARCO ANTONIO MARINELLI FILHO

\title{
Por uma fenomenologia da língua e do signo linguístico
}

\author{
Versão corrigida
}

Dissertação apresentada ao Programa de PósGraduação em Linguística, do Departamento de Linguística, da Faculdade de Filosofia, Letras e Ciências Humanas, da Universidade de São Paulo, como parte dos requisitos para obtenção do título de Mestre em Letras (Semiótica e Linguística Geral).

Orientador: Prof. Dr. Waldir Beividas. 
Autorizo a reprodução e divulgação total ou parcial deste trabalho, por qualquer meio convencional ou eletrônico, para fins de estudo e pesquisa, desde que citada a fonte.

Catalogação na Publicação

Serviço de Biblioteca e Documentação

Faculdade de Filosofia, Letras e Ciências Humanas da Universidade de São Paulo

M338u

Marinelli Filho, Marco Antonio

Por uma fenomenologia da língua e do signo

linguístico / Marco Antonio Marinelli Filho;

orientador Waldir Beividas. - São Paulo, 2019.

$131 \mathrm{f}$.

Dissertação (Mestrado)- Faculdade de Filosofia, Letras e Ciências Humanas da Universidade de São

Paulo. Departamento de Linguística. Área de

concentração: Semiótica e Linguística Geral.

1. Fenomenologia . 2. Signo linguístico. 3. Língua - I. Beividas, Waldir, orient. II. Título. 


\section{ENTREGA DO EXEMPLAR CORRIGIDO DA DISSERTACÃO/TESE \\ Termo de Ciência e Concordância do (a) orientador (a)}

Nome do (a) aluno (a): Marco Antonio Marinelli Filho

Data da defesa: $03 / 10 / 2019$

Nome do Prof. (a) orientador (a): Waldir Beividas

Nos termos da legislação vigente, declaro ESTAR CIENTE do conteúdo deste EXEMPLAR CORRIGIDO elaborado em atenção às sugestões dos membros da comissão Julgadora na sessão de defesa do trabalho, manifestando-me plenamente favorável ao seu encaminhamento e publicação no Portal Digital de Teses da USP.

São Paulo, 15 /10 /2019

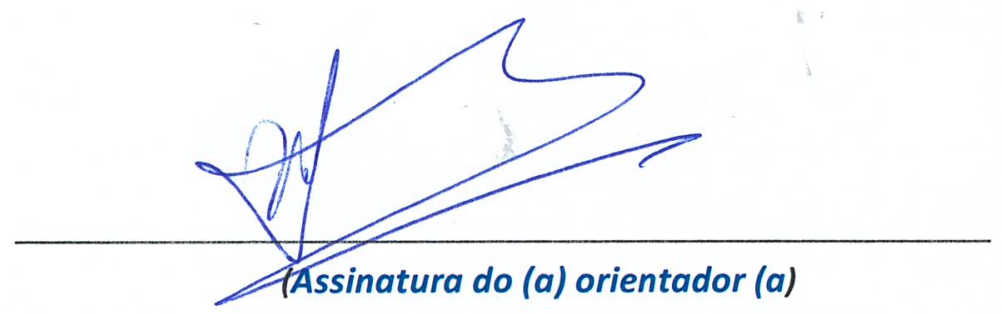


MARINELli FILHO, Marco Antonio. Por uma fenomenologia da língua e do signo linguístico. 2019. 130 f. Dissertação (Mestrado) - Faculdade de Filosofia, Letras e Ciências Humanas, Universidade de São Paulo, São Paulo, 2019.

Aprovado em:

Banca examinadora:

Prof(a). Dr(a).

Instituição

Julgamento Assinatura

Prof(a). Dr(a).

Instituição

Julgamento Assinatura

Prof(a). Dr(a). Instituição

Julgamento Assinatura

Prof(a). Dr(a). Instituição Assinatura 
E visto que a Semiótica constitui para nós a única forma de filosofia pensável...

ECO, 2010, p. 10

[Frederico II] quis experimentar que língua e idioma usavam as crianças que chegassem à adolescência sem jamais ter podido falar com ninguém. Por isso deu ordem às babás e às amas-de-leite de alimentar os bebês [...], com a proibição de falar com eles. Ele pretendia descobrir de fato se falassem a língua hebraica, se foi a primeira, ou a grega, ou a latina, ou a arábica; ou se continuassem a falar a língua dos próprios pais, dos quais eles nasceram. Mas seu esforço não deu qualquer resultado, porque todas as crianças ou bebês acabavam morrendo.

SALIMBE DE PARMA, Cronaca, n. 1664 (retirado de ECO, 2002, p. 16). 
Que as isoladas ideias filosóficas não sejam arbitrárias ou ideias que nasçam de si mesmas, mas que, ao contrário, gerem-se em afinidade entre si, e que, embora apareça de improviso na história do pensamento, cada conceito pertença a um sistema, da mesma forma que cada espécie animal pertence à fauna de um Continente, isto se manifesta precisamente na segurança com que os filósofos das escolas mais desvairadas sabem encher certo esquema fundamental das filosofias possíveis.

Como atraídos por um encanto invisível, movem-se novamente na mesma órbita, e quando se sintam independentes entre si pela vontade crítica ou sistemática, sempre há neles algo que os guia, que os incita a mover-se com passo cadenciado um atrás do outro, o qual consiste no sistema inato, na afinidade dos conceitos. Em suma, seu pensar não é tanto um descobrimento como uma recordação, como uma reminiscência, como um retorno à lonjura e antiquíssima economia complexa da alma, onde aqueles conceitos tiveram sua primeira origem: em tal sentido, o filosofar é uma espécie de atavismo de grau elevado.

A estranha semelhança que têm entre si as filosofias hindu, grega e germânica é fácil de demonstrar. Precisamente, onde subsiste uma afinidade de linguagem é absolutamente inevitável que, graças à comum filosofia da gramática, quero dizer, graças à inconsciente direção de iguais funções gramaticais, não esteja predisposto tudo a priori para um desenvolvimento análogo dos sistemas filosóficos, assim como parecem fechadas para a interpretação do universo outras possibilidades.

Os filósofos do território linguístico ural-altaico (onde o conceito de sujeito teve seu menor desenvolvimento) verão, provavelmente, as "coisas do mundo" muito diferentemente dos indo-germânicos ou dos muçulmanos; a proscrição de certas funções gramaticais são em última análise a proscrição dos juízos fisiológicos de valor e das condições de raça.

Isto é suficiente para refutar a superficialidade de Locke acerca da origem das ideias.

NIETZSCHE, 2014, p. 29/30 (itálicos no original).

A origem do nosso conceito de "conhecimento". - Esta explicação eu encontrei na rua; ouvi alguém do povo dizer: "Ele me reconheceu" - então me perguntei: o que entende mesmo o povo por "conhecimento"? Não mais do que isto: algo estranho deve ser remetido a algo conhecido. E nós, filósofos - já entendemos mais do que isso, ao falar de conhecimento? O conhecido, isto é, aquilo a que estamos habituados, de modo que não mais nos admiramos, nosso cotidiano, alguma regra em que estamos inseridos, toda e qualquer coisa em que nos sentimos em casa: - como? Nossa necessidade de conhecer não é justamente essa necessidade do conhecido, a vontade de, em meio a tudo o que é estranho, inabitual, duvidoso, descobrir algo que não mais nos inquiete? Não seria o instinto do medo que nos faz conhecer? E o júbilo dos que conhecem não seria precisamente o júbilo do sentimento de segurança reconquistado?... Eis um filósofo que deu o mundo por "conhecido", tendo-o remetido à "ideia": não seria porque a "ideia" lhe era tão familiar, tão habitual? Por que ele já a receava tão pouco? - Oh, que fácil satisfação a dos homens do conhecimento! Examine-se, quanto a isto, os seus princípios e soluções para os enigmas do mundo! Quando reencontram nas coisas, sob as coisas, por trás delas, algo que infelizmente nos é bem conhecido ou familiar, como a nossa tabuada, a nossa lógica ou nosso querer e desejar, como ficam imediatamente felizes! Pois "o que é familiar é conhecido": nisso estão de acordo. Também os mais cautelosos entre eles acham que ao menos o familiar é mais facilmente cognoscível do que o estranho; que o método exige, por exemplo, que se parta do "mundo interior", dos "fatos da consciência", pois este é o mundo mais familiar para nós! Erro dos erros! O familiar é o habitual; e o habitual é o mais difícil de "conhecer", isto é, de ver como problema, como alheio, distante, "fora de nós"... A grande segurança das ciências naturais, em relação à psicologia e à crítica dos elementos da consciência - ciências não naturais, poderíamos dizer -, reside justamente no fato de tomarem o estranho por objeto: enquanto é quase contraditório e absurdo querer tomar por objeto o não estranho...

NIETZSCHE, 2012, p. 224/225 (itálicos no original). 
Uma imagem mantinha-nos prisioneiros. E não podíamos escapar, pois ela residia em nossa linguagem, e esta parecia repeti-la para nós, inexoravelmente.

WITTGENSTEIN, 2014, p. 72.

Os resultados da filosofia são a descoberta de um absurdo simples qualquer e as mossas que o intelecto arranjou ao bater contra o limite da linguagem. Elas, as mossas, fazem-nos reconhecer o valor daquela descoberta.

WITTGENSTEIN, 2014, p. 73. 
(...).

$\mathrm{P}$ - Devo entender que a experiência dos senhores se move na distinção entre o mundo sensível e o supra-sensível? Nesta mesma distinção, repousa o que de há muito se chama de metafísica.

$\mathrm{J}$ - Com esta observação relativa à distinção metafísica, o senhor toca na fonte do perigo a que nos referimos. Nosso pensamento, caso possa falar assim, conhece sem dúvida algo semelhante à distinção metafísica. $\mathrm{E}$, no entanto, a distinção como tal e o que nela se distingue não pode ser apreendida pelos conceitos metafísicos do Ocidente. Assim, nos dizemos iro, a cor, e dizemos $k u$, o vazio, o aberto, o céu. E nós dizemos que sem iro não há $k u$, sem cor não há vazio.

$\mathrm{P}$ - Ora, isso parece corresponder precisamente ao que diz a doutrina europeia, isto é,

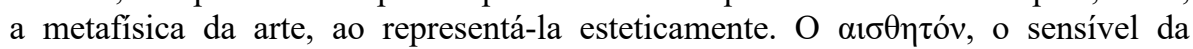
percepção, faz brilhar o voๆtóv, o não sensível.

$\mathrm{J}$ - O senhor compreende agora como era grande a tentação de Kuki de determinar o iki com a ajuda da estética europeia, isto é, de determiná-la metafisicamente, de acordo com suas palavras.

$\mathrm{P}$ - Ainda maior era e permanece o receio de que, seguindo este caminho, se encubra a essência própria da arte oriental e se transplante esta mesma essência para um âmbito que não lhe convém.

J - Partilho inteiramente deste receio. Pois iro diz, de fato, a cor, mas, na verdade, designa muito mais do que o perceptível pelos vários tipos de sentido. De fato, $k u$ diz o vazio e o aberto mas na verdade designa outra coisa do que o mero supra-sensível. $\mathrm{P}$ - Só de longe posso acompanhar essas explicações. Todavia, elas aumentam minha inquietação. Maior do que o receio mencionado é a esperança de que nossa conversa nascida de uma recordação do conde Kuki venha a ter êxito.

$\mathrm{J}$ - O senhor quer dizer que ela nos poderia levar para mais perto do não-dito.

P - Com isso ser-nos-ia concedido todo um acervo de coisas dignas de serem pensadas.

J - Por que o senhor diz "ser-nos-ia"?

$\mathrm{P}$ - Porque agora vejo ainda mais nitidamente o perigo de que a língua de nossa conversa destrua continuamente a possibilidade de dizer o que estamos discutindo.

$\mathrm{J}$ - É porque a própria língua repousa sobre a distinção metafísica entre sensível e não-sensível, uma vez que os elementos fundamentais, fonema e grafema, de um lado, e significado e sentido, do outro, sustentam toda a estrutura da língua.

$\mathrm{P}$ - Ao menos no âmbito da representação europeia. Será que é assim também no Japão?

J - Na verdade, dificilmente pode ser assim. Grande, no entanto, é a tentação de recorrer aos préstimos da representação europeia e de seus conceitos, como mencionei acima.

(...).

HEIDEGGER, 2003, trecho retirado do capítulo "De uma conversa sobre a linguagem entre um japonês e um pensador", p. 83/84 (itálicos no original).

Quanto à inadequação e "falta de beleza" do estilo das análises que se seguirão, devese observar o seguinte: uma coisa é fazer um relatório narrativo sobre os entes, outra coisa é apreender o ente em seu ser. Para esta última tarefa não apenas faltam, na maioria das vezes, palavras, mas, sobretudo, gramática.

HEIDEGGER, 2015, p. 79 (itálicos no original). 
... filosofia pode ser linguística pode ser filosofia pode ser linguística pode ser filosofia pode ser linguística pode ser filosofia pode ser linguística ... 


\section{AGRADECIMENTOS}

Se hoje faço o que amo...

Faço-o, e só posso fazê-lo, porque meus pais, Liane e Marco, por mim, fazem de tudo, inclusive o que detestam, e, tantas vezes, deixam de fazer o que amam.

Faço-o porque minha irmã, Bia, me mostrou que é possível superar quaisquer dificuldades, mesmo as que vêm de dentro e, por isso, apenas parecem incontornáveis.

Faço-o porque o amor da minha vida, Giulia, permitiu-me compreender o amor. E, uma vez que se compreende o amor, acha-se que tudo pode ser compreendido, pois tudo passa a ter sentido.

Faço-o porque meu cachorro, Fred, me mostrou que a persistência vale a pena (ele não desiste de pedir e sempre consegue dormir dentro de casa).

Faço-o porque meu orientador, Waldir, cometeu as insanidades de me aprovar na entrevista de admissão do mestrado e de me adotar como orientando.

Faço-o porque meus professores Márcio e Willis insistem em superestimar minha capacidade e, de tanto insistirem, às vezes me pego acreditando nessa superestimação.

Faço-o porque a família Gesusp, que é o mais amável grupo de estudos da linguística, torna tudo ainda mais amável, inclusive o que já se amava.

Faço-o porque, dentro dessa família, encontrei amizades inestimáveis: Adriana, Andréa, Fernando, Gustavo, Hadassa, Joyce, Léo, Milton, Túlio e Vinícius.

Faço-o, enfim, porque tenho o privilégio de conviver com inspirações vivas: Clarice von Oertzen de Araújo, Dilson Ferreira da Cruz Junior, Ivã Carlos Lopes, Luiz Augusto de Moraes Tatit, Márcio Pugliesi, Tércio Sampaio Ferraz Junior, Waldir Beividas e Willis Santiago Guerra Filho. 


\section{RESUMO}

MARINELli FILHO, Marco Antonio. Por uma fenomenologia da língua e do signo linguístico. 2019. 130 f. Dissertação (Mestrado) - Faculdade de Filosofia, Letras e Ciências Humanas, Universidade de São Paulo, São Paulo, 2019.

A intenção que motivou a idealização e a realização desta dissertação de mestrado foi a de demonstrar a possibilidade de uma fenomenologia da língua e do signo linguístico. A fenomenologia em questão é a definida por Martin Heidegger como um "deixar e fazer ver por si mesmo aquilo que se mostra, tal como se mostra a partir de si mesmo" (2015, p.74); é, em outros termos, o interpretar que, ao analisar e explicar algo, revela-o ao enunciá-lo. E o que a fenomenologia deixa e faz ver é o "ser"- que é sempre ser de um "ente". Uma fenomenologia da língua e do signo linguístico seria, portanto, o deixar e fazer ver por si mesmo o ser da língua e o ser do signo, assumidos como entes. A forma imaginada para demonstrar a possibilidade dessa fenomenologia foi: encontrar interpretações de natureza fenomenológica em meio a interpretações fornecidas por autores que buscaram analisar a língua e o signo linguístico através da aplicação de uma metodologia essencialmente não-fenomenológica. Os autores selecionados foram Ferdinand de Saussure, Louis Hjelmslev, Roland Barthes, Umberto Eco e Izidoro Blikstein e a metodologia em questão é o estruturalismo linguístico. Em suma, o que qualifica o estruturalismo linguístico como metodologia é a intenção de compreender e explicar seus objetos através da projeção de um modelo de estrutura (ou modelo estrutural) sobre esses objetos; isto é, é a intenção de compreendê-los e explicá-los como se fossem estruturas correspondentes ao modelo de estrutura pré-estabelecido. Com isso, por partir de algo externo ao objeto (o modelo de estrutura) para analisá-lo e explicá-lo, o estruturalismo linguístico não o questiona e nem busca questioná-lo em seu próprio modo de ser. Logo, identificar argumentos de caráter fenomenológico, inconscientemente presentes, no interior de analises baseadas na metodologia do estruturalismo linguístico, é demonstrar a possibilidade de realização consciente de uma fenomenologia da língua e do signo linguístico. Para esses propósitos, a dissertação foi dividida em três partes. A primeira dedicada à introdução. A segunda dedicada à demonstração da viabilidade de uma fenomenologia da língua e do signo linguístico através da análise das obras dos cinco autores acima mencionados. E a terceira dedicada às considerações finais. 


\begin{abstract}
MARINELLI FILHO, Marco Antonio. For a phenomenology of language and linguistic sign. 2019. 130 f. Dissertação (Mestrado) - Faculdade de Filosofia, Letras e Ciências Humanas, Universidade de São Paulo, São Paulo, 2019.
\end{abstract}

The intention that motivated the idealization and the realization of this master thesis was to demonstrate the possibility of a phenomenology of the language and the linguistic sign. The phenomenology in question is that defined by Martin Heidegger as "letting and seeing for oneself what one shows, as one shows oneself" $(2015$, p.74); it is, in other words, the interpretation that, when analyzing and explaining something, reveals it by stating it. And what phenomenology leaves and reveals is "being" - which is always being of a "being". A phenomenology of language and of the linguistic sign would therefore be to let itself be seen by the being of the language and the being of the sign, assumed as beings. The imagined way to demonstrate the possibility of this phenomenology was to find interpretations of a phenomenological nature amid interpretations provided by authors who sought to analyze language and the linguistic sign through the application of an essentially non-phenomenological methodology. The selected authors were Ferdinand de Saussure, Louis Hjelmslev, Roland Barthes, Umberto Eco and Izidoro Blikstein and the methodology in question is linguistic structuralism. In short, what qualifies linguistic structuralism as a methodology is the intention to understand and explain its objects by projecting a structural model (or structural model) onto these objects; that is, it is the intention to understand and explain them as if they were structures corresponding to the pre-established structure model. Thus, by starting from something external to the object (the structure model) to analyze and explain it, linguistic structuralism neither questions nor seeks to question it in its own way of being. Therefore, to identify unconsciously present phenomenological arguments within analyzes based on the methodology of linguistic structuralism is to demonstrate the possibility of conscious realization of a phenomenology of language and linguistic sign. For these purposes, the dissertation was divided into three parts. The first dedicated to the introduction. The second is dedicated to demonstrating the viability of a phenomenology of language and linguistic sign through the analysis of the works of the five authors mentioned above. And the third dedicated to the final considerations. 


\section{LISTA DE FIGURAS}

Figura 1 - O triângulo de Ogden e Richards

Figura 2 - A iteração língua/práxis 


\section{SUMÁRIO}

CAPítULO 1. APRESENTAÇÃo da DisSERTAÇÃo.

CAPÍTULO 2. JUSTIFICANDO O TÍTULO DA DISSERTAÇÃO.

CAPÍTULO 3. O ESTRUTURALISMO LINGUÍSTICO E OS AUTORES ESCOLHIDOS.

CAPÍTULO 4. A fENOMENOLOGIA dE HEIDEgGER E SUA DEFINIÇÃo.

CAPÍTULO 5. UMA FENOMENOLOGIA DA LÍNGUA E DO SIGNO LINGUíSTICO NO ESTRUTURALISMO LINGUíSTICO. 27

CAPítulo 1. Ferdinand de SAUSSURE.

\begin{tabular}{l} 
A) PRELIMINARMENTE \\
\hline B) ALINGUA
\end{tabular}

B) A LÍNGUA $\quad 31$

C) E O SIGNO LINGUÍSTICO $\quad 41$

CAPÍtUlo 2. LoUIS HJELMSLEV. $\quad 50$

A) PreLiminARMENTE $r$

B) A LÍNGUA $\quad 51$

C) E O SIGNO LINGUÍSTICO $\quad 67$

CAPÍtUlo 3. ROLAND BARTHES. $\quad 72$

A) Preliminarmente $\quad 72$

B) A LÍNGUA $r$

C) E O SIGNO LINGUÍSTICO $\quad 78$

CAPÍtUlo 4. UMBERTO ECO. $\quad 83$

A) PRELIMINARMENTE $\quad 83$

B) A LÍNGUA $\quad 84$

$\begin{array}{lr}\text { C) E O SIGNO LINGUÍSTICO } & 99\end{array}$

CAPÍTULO 5. IZIDORO BLIKSTEIN. $\quad 105$

$\begin{array}{lr}\text { A) Preliminarmente } & 105\end{array}$

B) A LÍNGUA $r \begin{array}{r}105 \\ \hline \text { C) OSIGNOLNGUISTICO }\end{array}$

C) E O SIGNO LINGUÍSTICO $r$\begin{tabular}{l}
121 \\
\hline
\end{tabular}

\begin{tabular}{lr} 
PARTE III - CONSIDERAÇÕES FINAIS & 125 \\
\hline
\end{tabular}

$\begin{array}{lr}\text { CAPÍTULO ÚNICO. } & 126\end{array}$

\begin{tabular}{lr} 
REFERÊNCIAS & 129 \\
\hline
\end{tabular} 
PARTE I

INTRODUÇÃO 


\section{Capítulo 1. Apresentação da dissertação.}

Há duas formas de apresentar o que virá escrito a seguir: como sonho concretizado e como dissertação de mestrado.

O sonho era extrair de mim algo que sonhava (e me atormentava) sobre a língua e sobre o signo linguístico. Sonho que conscientemente tentei sossegar, de que conscientemente tentei me desviar, mas que, inexoravelmente, impôs-se a mim... - viva-me! Vivi-o, entregueime, ei-lo: um sonho estranho, que não é, certamente, daqueles sonhos mais belos, que se consegue lembrar mesmo depois de acordar; daqueles que, se se pudesse escolher com o que sonhar, escolhê-los-ia. É um sonho intrincado, longe de ser tranquilo, longe de ser desejado. É um sonho que provoca, e por tanto provocar, por vezes provoca dor de cabeça ao acordar.

Porque concretizado, não é mais, de fato, um sonho. Posso lê-lo, podem lê-lo. Concretizado, é agora apenas mais um singelo passo em direção ao maior sonho: tornar-me professor.

Como dissertação de mestrado, é o produto escrito de um estudo sobre a língua e o signo linguístico. Um estudo que pode ser descrito como um processo (e cujos fundamentos teóricos serão descritos ao longo desta longa introdução). Como um processo que se encerra com esta dissertação, o estudo pode ser dividido em duas etapas: a etapa da leitura e a etapa da redação (respaldada por releituras específicas). A etapa da leitura durou praticamente um ano - intervalo que levei para finalmente definir o tema da dissertação. A etapa da redação começou na última semana de dezembro do ano passado e estendeu-se até o final de julho deste ano, mais ou menos sete meses. E esse longo período de redação provocou uma curiosa consequência, que o leitor certamente notará: o estilo de minha escrita variou ao longo do texto. Não digo que evoluiu ou mesmo que involuiu, mas que, simplesmente, não foi uniforme. Talvez o tempo inevitavelmente provoque essa variação, talvez as releituras paralelas à redação tenham sido capazes de influenciar o modo que escrevia, ou mesmo talvez... como saber. O importante era alertar para prevenir qualquer estranheza.

E que estranheza a estrutura de distribuição de capítulos que imaginei para esta dissertação deve ter causado. Uma introdução tão grande, uma segunda parte só de nomes de autores e uma conclusão separada de tudo. Não sei se minhas escolhas foram as melhores, corretas, pertinentes... sei que foram verdadeiras, sei que foram o que melhor pude imaginar para tentar expor da melhor forma o que pretendia expor.

Enfim, o que está por vir veio do coração. De onde mais poderia tê-lo extraído? 


\title{
Capítulo 2. Justificando o título da dissertação.
}

\begin{abstract}
Outras ciências trabalham com objetos dados previamente e que se podem considerar, em seguida, de vários pontos de vista; em nosso campo, nada de semelhante ocorre. Alguém pronuncia a palavra $n u$ : o observador superficial será tentado a ver nela um objeto linguístico concreto; um exame mais atento, porém, nos levará a encontrar no caso, uma após outra, três ou quatro coisas perfeitamente diferentes, conforme a maneira pela qual consideramos a palavra: como som, como expressão duma ideia, como correspondente ao latim nudum etc. Bem longe de dizer que o objeto precede o ponto de vista, diríamos que é o ponto de vista que cria o objeto; aliás, nada nos diz de antemão que uma dessas maneiras de considerar o fato em questão seja anterior ou superior às outras. (Saussure, 2012A, p. 39, itálicos no original).
\end{abstract}

A presente dissertação de mestrado foi imaginada e realizada em favor de uma fenomenologia da língua e do signo linguístico - este o porquê do título "por uma fenomenologia da língua e do signo linguístico". Título que para mim é deveras valioso, pois é suficientemente conciso para ser repulsivo, e suficientemente informativo para ser atrativo. E, por outro lado, se parece nada dizer, ao menos lança ao leitor curioso atraído por esse nada-dito pistas dos objetos analisados e do objetivo da investigação.

Os objetos que escolhi analisar foram a língua e o signo linguístico. "Língua" compreendida como "Sistema de símbolos convencionais orais por meio dos quais os seres humanos como membros de um grupo social e participantes de uma cultura, comunicam-se e expressam pensamentos, desejos e emoções; idioma." (Dicionário escolar da língua portuguesa, 2008) ou, em outros termos, como "5. LING sistema de representação constituído por palavras e por regras que as combinam em frases que os indivíduos de uma comunidade linguística usam como principal meio de comunicação e de expressão, falado ou escrito 5.1 abs. o idioma nacional" (HOUAISS e VILLAR, 2009). Em suma, compreendida como aquilo que nos permite compreender o mundo e falar sobre o mundo desde quando nascemos, mas que sobrevive quando morremos. E "signo linguístico" compreendido como "Elemento da linguagem que associa uma imagem acústica (significante) a um conceito (significado)" (Dicionário escolar da língua portuguesa, 2008); em termos bem semelhantes: "Unidade linguística que consiste na combinação de uma imagem acústica, o significante, e de um conceito, o significado; signo linguístico.” (Michaelis online, 2019) ${ }^{1}$.

\footnotetext{
${ }^{1}$ Para melhor compreender essa definição de signo linguístico, ver o capítulo $\mathrm{n} .1$, da parte II, desta dissertação (dedicado a Ferdinand de Saussure).
} 
Analisar a língua e o signo linguístico mostrou-se, desde logo, como uma tarefa problemática. A possibilidade de qualquer análise que se pretenda realizar pressupõe a possibilidade de se observar o objeto que se pretenda analisar. Não é possível analisar algo que não se pode observar. Eis o problema: a língua é algo que parece estar em todos os lugares enquanto parece não estar em lugar nenhum; e o signo linguístico é algo não tão delimitado e não tão definido, pois várias coisas muito diversas parecem significar (ser o significante de) um significado. Ou seja, a língua parece ser algo inapreensível, enquanto o signo linguístico, apesar de apreensível, é-o de tantos modos que passa a também parecer inapreensível. Como então acessar para observar esses dois objetos? É certo que não poderia alcançar esse acesso sozinho; tentá-lo, não obstante a impossibilidade que se impõe a esse intuito, seria talvez nobre, ou talvez louco, mas certamente imprudente em nível de mestrado.

Decidi então recorrer a quem já havia conseguido de algum modo esse feito, os autores que selecionei com base no seguinte critério: apresentar relação próxima com o estruturalismo linguístico ${ }^{2}$. As obras desses autores revelam que conseguiram alcançar e observar a língua e o signo linguístico; com isso, puderam analisá-los e interpretá-los. A interpretação inevitavelmente confere ao objeto interpretado alguma determinação; e, se se interpreta, acabase definindo e explicando de algum modo o interpretado - o ponto de vista cria o objeto. E foi isso que encontrei nas obras desses autores: diferentes modos de interpretar, definir e explicar a língua e o signo linguístico. Cada autor me concedeu um diferente modo de acessar e observar esses dois objetos, ainda que indiretamente. Se buscava a princípio um único modo para observar e analisar meus objetos, deparei-me com cinco (o que também deixa evidente a metodologia de pesquisa adotada: a pesquisa bibliográfica).

O objetivo de minha dissertação, em alguma medida adiantado pelo título, é demonstrar a possibilidade de uma fenomenologia da língua e do signo linguístico. Isto é, a possibilidade de se interpretar a língua e o signo linguístico fenomenologicamente. A fenomenologia como método ontológico de análise de um objeto será melhor explicada abaixo, em capítulo próprio. Também em capítulo próprio, explicarei como pretendo demonstrar a possibilidade da interpretação fenomenológica de meus objetos e também qual a relação dessa possibilidade com o estruturalismo linguístico. Por ora, cabe resumir o que passou e apresentar o que ainda virá nessa introdução.

Resumindo o que passou: a análise que realizarei nesta dissertação possui dois objetos definidos (a língua e o signo linguístico), uma metodologia de pesquisa (pesquisa bibliográfica),

\footnotetext{
${ }^{2} \mathrm{O}$ tipo de relação, a proximidade e o que é o estruturalismo linguístico serão explicados no capítulo seguinte (n. 3 , parte I).
} 
um critério de seleção de autores da bibliografia (relação com o estruturalismo linguístico) e um método para interpretar os objetos pesquisados (a fenomenologia).

E o que virá: esclarecerei o que é o estruturalismo linguístico e quais foram os autores escolhidos (capítulo 3, parte I); explicarei como compreendo a fenomenologia (capítulo 4, parte I); e, por fim, explicarei minha proposta para a presente dissertação, isto é, como pretendo demonstrar a possibilidade de uma fenomenologia da língua e do signo linguístico baseandome na interpretação que os autores relacionados ao estruturalismo linguístico fizeram desses dois objetos (capítulo 5, parte I). 


\title{
Capítulo 3. O estruturalismo linguístico e os autores escolhidos.
}

O estruturalismo linguístico é uma postura metodológica que caracteriza um conjunto de pesquisas e estudos realizados na área da Linguística. Essencialmente, o que qualifica o estruturalismo linguístico como metodologia é a intenção de compreender e explicar seus objetos através da projeção de um modelo de estrutura (ou modelo estrutural) sobre esses objetos; ou seja, é a intenção de compreendê-los e explicá-los como se fossem estruturas correspondentes a um modelo de estrutura pré-estabelecido.

\begin{abstract}
Entende-se por linguística estrutural um conjunto de pesquisas que repousam em uma hipótese segundo a qual é cientificamente legítimo descrever a linguagem como sendo essencialmente uma entidade autônoma de dependências internas ou, numa palavra, uma estrutura.

Cumpre primeiramente insistir no caráter hipotético dessa proposição inicial. Com efeito, o enunciado ora formulado não possui o caráter de um dogma ou de um julgamento apriorístico. Trata-se de uma simples hipótese de trabalho, considerada útil na busca de uma verificação pela dupla razão de a possibilidade dessa hipótese ter sido até aqui, as mais das vezes, negligenciada, e de certos fatos, suficientemente numerosos e fáceis de observar, induzirem a crer que ela poderia justificar-se. Por mais que se deseje qualificá-la de doutrina, é uma doutrina que não se mantém senão a título de hipótese. Por mais que se queira qualificá-la de axioma, lembremos que a lógica nos ensina que todo axioma pode ser reduzido a uma definição ou a uma hipótese. (HJELMSLEV, 1991, p. 29/30, itálicos no original).
\end{abstract}

Um modelo é algo que não pertence a nenhum objeto, mas que se pode projetar sobre qualquer objeto como técnica para compreendê-lo e explicá-lo - é uma hipótese explicativa. É algo criado para permitir a compreensão e explicação de qualquer objeto que se pretenda analisar. E a estrutura é um sistema formado (a) por elementos dotados de valor sistemático e (b) por relações de diferença e oposição existentes entre tais elementos ${ }^{3}$. Existir como elementos num sistema é ter valor sistemático; e ter valor sistemático é ser diferente dos demais elementos do sistema, é valer o que os demais não valem.

Examinaremos, portanto, uma série de textos ligados por uma coerência de impostação e por influências documentadas, fazendo emergir através deles estes três pontos fundamentais:

a) uma estrutura é um modelo como sistema de diferenças;

\footnotetext{
${ }^{3}$ No capítulo sobre Saussure (capítulo 1, parte II) o conceito de sistema de diferenças e oposições será melhor desenvolvido, bem como o conceito de valor.
} 
b) característica desse modelo é a sua transponibilidade de fenômeno para fenômeno e de ordens de fenômenos para ordens de fenômenos diferentes;

c) uma metodologia "estrutural" só terá sentido se forem respeitados os dois postulados precedentes, e só a esse título permitirá uma análise interdisciplinar que abra o caminho para uma unificação do saber e uma direção a fecundas relações entre as várias ciências humanas. (ECO, 2013, p. 258, itálicos no original).

Assim, o modelo de estrutura, ou modelo estrutural, é algo que se pode projetar sobre um ou mais objetos no intuito de compreendê-los e explicá-los como sistemas de diferenças e oposições entre elementos. Consequentemente, e sendo um tanto repetitivo, o estruturalismo linguístico é a metodologia que propõe a adoção de um modelo de estrutura como técnica para compreender e explicar seus objetos de análise como se fossem sistemas de diferenças e oposições existentes entre seus elementos constitutivos.

O que o estruturalismo linguístico tornou evidente, já vimos, não foi o fato de uma estrutura ser um sistema de partes solidárias e interdependentes, mas o fato de que essa estrutura possa ser expressa em termos de oposições e diferenças, independentemente dos elementos que passam a colmar as valências constituídas pelos polos oposicionais e diferenciais. Em decorrência, a metodologia estruturalista mostra-se capaz de analisar unidades relacionadas e organizadas. (ECO, 2013, p. 269).

E se o estruturalismo linguístico é essa metodologia que possui uma técnica bem determinada de análise de objetos (o modelo de estrutura); por outro lado, apresenta uma vastíssima gama de objetos analisáveis. Tudo que puder ser relacionado à linguagem humana enquanto um fenômeno poderá ser objeto da Linguística e, portanto, poderá ser objeto do linguista que decidir adotar o estruturalismo linguístico como metodologia de análise. Tudo poderá ser compreendido e explicado como um sistema de diferenças e oposições ou como elemento de um sistema deste tipo.

Toda descrição científica pressupõe que o objeto da descrição seja concebido como uma estrutura (portanto, analisado segundo um método estrutural que permita reconhecer relações entre as partes que o constituem) ou como parte de uma estrutura (portanto, sintetizado com outros objetos com os quais contrai relações que tornam possível estabelecer e reconhecer um objeto mais extenso do qual esses objetos, com o objeto considerado, são partes). (HJELMSLEV, 1991, p. 116). 
Porém, dentre todos esses objetos estudáveis e dentre todos os que já foram e continuam sendo estudados, busquei aproveitar o que já foi desenvolvido acerca da língua e do signo linguístico. Procurei utilizar os resultados que a aplicação dessa metodologia trouxe para a compreensão e explicação da língua e do signo linguístico. E a forma de fazê-lo foi a seleção de autores relacionados ao estruturalismo linguístico, seja porque de fato aplicaram essa metodologia, seja porque foram assumidamente influenciados por aqueles que aplicaram essa metodologia.

Os autores selecionados foram Ferdinand de Saussure, Louis Hjelmslev, Roland Barthes, Umberto Eco e Izidoro Blikstein. Saussure e Hjelmslev são os estruturalistas originais - o conjunto de suas produções científicas é a corporificação do estruturalismo linguístico como metodologia. Barthes desenvolveu toda uma semiologia baseada na metodologia do estruturalismo linguístico. Eco não esconde as influências que sofreu de Saussure e, especialmente, de Hjelmslev; e em A estrutura ausente (2013) defende o estruturalismo metodológico (enquanto critica o estruturalismo ontológico) ${ }^{4}$. Por fim, Blikstein também deixa evidente tudo que absorveu de Saussure, sendo inevitável concluir que grande parte de suas conclusões são derivadas do estruturalismo linguístico.

Foram esses autores que me permitiram de algum modo acessar e analisar a língua e o signo linguístico. Foi na interpretação que esses autores fizeram sobre a língua e o signo linguístico que busquei encontrar lampejos de caráter fenomenológico e expô-los nos capítulos da parte II.

\footnotetext{
${ }^{4}$ Essa passagem da introdução de seu livro ilustra bem a oposição entre estruturalismo defendido e estruturalismo criticado: "O que se pede ao leitor é que nunca se fie nas asserções de um capítulo tomado isoladamente. E se depois - impelido pelas exigências da atualidade - quiser esse leitor indagar se o livro é 'estruturalista' ou 'antiestruturalista', previne-o o autor de que aceitará de bom grado ambos os rótulos.” (2013, p. XXI).
} 


\section{Capítulo 4. A fenomenologia de Heidegger e sua definição.}

A fenomenologia, compreendo-a como define-a Martin Heidegger em sua obra Ser e tempo. Com isso, se o objetivo declarado desta dissertação é demonstrar a possibilidade de uma fenomenologia da língua e do signo linguístico, a fenomenologia em questão deve ser compreendida segundo a definição que Heidegger propõe para esse conceito.

Mas, por que Heidegger? Porque o único contato minimamente profundo que mantive com uma fenomenologia foi estabelecido através de sua obra. Se alguma coisa hoje sei sobre fenomenologia, esse conhecimento foi com ele obtido. Esse esclarecimento de caráter bibliográfico constitui também um alerta, que é provavelmente o mais importante desta Introdução. Para bem compreender tudo que será desenvolvido daqui para frente, o leitor deverá ter em mente que as considerações de caráter fenomenológico não sofreram qualquer influência direta (e a influência indireta é incalculável) das fenomenologias de Hegel, de Husserl, de Sartre, de Merleau-Ponty... ou mesmo de tudo aquilo que, em semiótica francesa, foi produzido durante e após o denominado tournant phénoménologique.

Pois bem, Heidegger define a fenomenologia do seguinte modo:

Fenomenologia diz, então: $\alpha \pi$ mesmo aquilo que se mostra, tal como se mostra a partir de si mesmo. É este o sentido formal da pesquisa que traz o nome de fenomenologia. Com isso, porém, não se faz outra coisa do que exprimir a máxima formulada anteriormente - "para as coisas elas mesmas!". (2015, p. 74).

O deixar e fazer ver por si mesmo é a atitude que decorre do logos, morfema que compõe a expressão fenomenologia. O logos corresponde ao termo grego $\lambda o ́ \gamma o \varsigma$, que é traduzido de modo literal pelo termo português "fala". No entanto, "Quando dizemos que o significado básico de $\lambda o ́ \gamma o \varsigma$ é fala, essa tradução literal só terá valor completo quando se determinar o que é uma fala.” (2015, p. 71, itálicos no original).

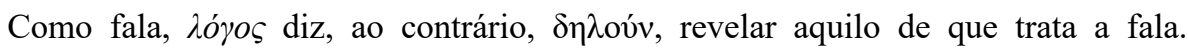
Aristóteles explicitou mais precisamente esta função da fala, determinando-a como $\alpha \pi \circ \varphi \alpha i ́ v \varepsilon \sigma \theta \alpha$ l. O $\lambda o ́ \gamma o \varsigma$ faz e deixa ver ( $\varphi \alpha i ́ v \varepsilon \sigma \theta \alpha$ ) $)$ aquilo sobre o que se discorre e o faz para quem fala (medium) e para todos aqueles que falam uns com os outros. A fala "deixa e faz ver" $\alpha \pi$ o ... a partir daquilo sobre o que fala. A fala ( $\alpha \pi$ ó $\varphi \alpha v \sigma ı)$ ) autêntica é aquela que retira o que diz daquilo sobre que fala, de tal maneira que, em sua fala, a comunicação falada revele e, assim, torne acessível aos outros, aquilo sobre que fala. 
Esta é a estrutura do $\lambda o ́ \gamma o \varsigma$ como $\alpha \pi$ ópavoıs. Nem toda fala, porém, possui este modo próprio de revelação no sentido de deixar e fazer ver, demonstrando. Um pedido

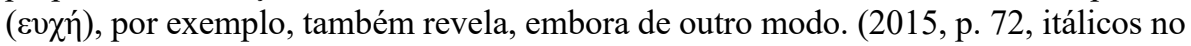
original).

A logia é o exercício do logos, é o exercício da fala, é o falar que representa um deixar e fazer ver por si mesmo aquilo sobre que se fala ao torná-lo acessível para aquele que fala e para aqueles com quem se fala. A fenomenologia, então, seria o falar que deixa e faz ver por si mesmo o "fenômeno", aquilo sobre que a fenomenologia fala. E o "fenômeno", segundo Heidegger, é:

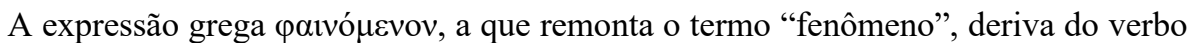

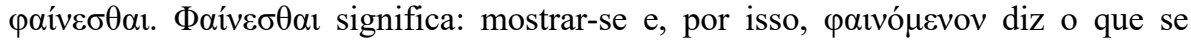

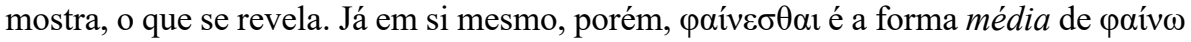
- trazer para a luz do dia, pôr no claro. $\varphi \alpha i ́ v \omega$ pertence à raiz $\varphi \alpha$, como $\varphi \omega \varsigma$, a luz, a claridade, isto é, o elemento, o meio, em que alguma coisa pode vir a se revelar e a se tornar visível em si mesma. Deve-se manter, portanto, como significado da expressão "fenômeno" o que se revela, o que se mostra em si mesmo. (2015, p. 67, itálicos no original).
\end{abstract}

O fenômeno é aquilo que se mostra em si mesmo. Mas esse mostrar-se possui uma peculiaridade, possui sempre um modo. O modo reflete o como "alguma coisa pode vir a se revelar e a se tornar visível em si mesma". O mostrar-se é sempre mostrar-se de algum modo, e é o modo de mostrar-se que caracteriza o fenômeno como um "modo privilegiado de encontro" (2015, p.70), pois direto. Ao mostrar-se em si mesmo tal como se mostra a partir de si mesmo, o fenômeno vai de encontro à apreensão, vai de encontro a quem pode e quer apreendê-lo por esse encontro privilegiado.

A definição de fenomenologia como a fala sobre os fenômenos - como deixar e fazer ver aquilo que se mostra em si mesmo, tal como se mostra a partir de si mesmo - permite a Heidegger diferenciá-la das demais ciências (falas) também denominadas pelo morfema logia.

O termo fenomenologia tem, portanto, um sentido diferente das designações como teologia, etc. Estas evocam os objetos de suas respectivas ciências, em seu conteúdo quididativo. O termo "fenomenologia" não evoca o objeto de suas pesquisas nem caracteriza o seu conteúdo quidativo. A palavra se refere exclusivamente ao modo como se demonstra e se trata $o$ que nesta ciência deve ser tratado. Ciência "dos" fenômenos significa: apreender os objetos de tal maneira que se deve tratar de tudo que está em discussão, numa demonstração e procedimento diretos. $\mathrm{O}$ mesmo sentido 
possui a expressão, no fundo tautológica, de "fenomenologia descritiva". Descrição não indica aqui um procedimento nos moldes, por exemplo, da morfologia botânica. A expressão tem novamente um sentido proibitivo: afastar toda determinação que não

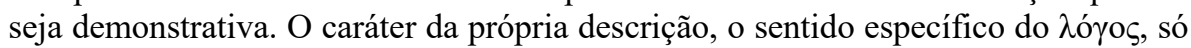
poderá ser estabelecido a partir da "própria coisa" que deve ser descrita, ou seja, só poderá ser determinado cientificamente segundo o modo em que os fenômenos vêm ao encontro. Considerado formalmente, o significado do conceito formal e vulgar de fenômeno legitima a denominação de fenomenologia a toda demonstração de um ente tal como se mostra em si mesmo. (2015, p. 74/75, itálicos no original).

Portanto, a fenomenologia não busca evocar seus objetos para apreender o "seu conteúdo quididativo". Seu papel é descrever e demonstrar (deixar e fazer ver) exatamente o modo como o fenômeno se mostra em si mesmo e, com isso, vem ao encontro da apreensão. A fenomenologia busca demonstrar o como é (o modo como algo se mostra em si mesmo) e não o que é (a quididade de algo): “A expressão 'fenomenologia' significa, antes de tudo, um conceito de método. Não caracteriza a quididade real dos objetos da investigação filosófica, o quê dos objetos, mas o seu modo, o como dos objetos." (2015, p. 66, itálicos no original).

Contudo, a definição de fenômeno, como aquilo que se mostra em si mesmo, demanda ainda uma especificação propriamente fenomenológica.

\begin{abstract}
A pergunta agora é como se deve desformalizar o conceito formal de fenômeno e transformá-lo em conceito fenomenológico, e como o conceito fenomenológico de fenômeno se distingue do conceito vulgar. O que será que a fenomenologia deve "deixar e fazer ver"? O que é que se deve chamar de "fenômeno" num sentido privilegiado? $\mathrm{O}$ que, em sua essência, é necessariamente tema de uma demonstração explícita? Justo o que não se mostra numa primeira aproximação e na maioria das vezes, mantendo-se velado frente ao que se mostra numa primeira aproximação e na maioria das vezes, mas que, ao mesmo tempo, pertence essencialmente ao que se mostra numa primeira aproximação e na maioria das vezes a ponto de constituir o seu sentido fundamental. (2015, p. 75, itálicos no original).

No entanto, como se mostrou nas considerações precedentes, o que, num sentido extraordinário, se mantém velado ou volta novamente a encobrir-se ou ainda só se mostra "distorcido" não é este ou aquele ente, mas o ser dos entes. O ser pode-se encobrir tão profundamente que chega a ser esquecido, e a questão do ser e de seu sentido se ausentam. O que, portanto, num sentido privilegiado e em seu conteúdo mais próprio, exige tornar-se fenômeno é o que a fenomenologia tematicamente tomou em suas garras como objeto. (2015, p. 75 , itálicos no original).
\end{abstract}

A desformalização proposta finalmente revela e determina o que são os "fenômenos" para a fenomenologia, o que são seus objetos, "as coisas elas mesmas" que se mostram em si mesmas. O sentido formal e vulgar permitia imaginar que a fenomenologia deixa e faz ver o 
ente $e^{5}$ tal como se mostra em si mesmo. Porém, o verdadeiro objeto da fenomenologia não é o ente, mas o ser do ente. Ou seja, o fenômeno que é descrito e demonstrado pela fenomenologia, o fenômeno que a fenomenologia deixa e faz ver é o ser do ente. E se o objeto da fenomenologia é o ser do ente, então a fenomenologia é uma ontologia; é, na verdade, o que possibilita a ontologia:

\begin{abstract}
A fenomenologia é a via de acesso e o modo de comprovação para se determinar o que deve constituir tema da ontologia. Ontologia só é possivel como fenomenologia. O conceito fenomenológico de fenômeno propõe, como o que se mostra, o ser dos entes, o seu sentido, suas modificações e derivados. Pois, o mostrar-se não é um mostrar-se qualquer e, muito menos, uma manifestação. $\mathrm{O}$ ser dos entes nunca pode ser uma coisa "atrás" da qual esteja outra coisa "que não se manifesta". (2015, p. 75). "Atrás" dos fenômenos da fenomenologia não há absolutamente nada. Contudo, aquilo que deve tornar-se fenômeno pode velar-se. A fenomenologia é necessária justamente porque, numa primeira aproximação e na maioria das vezes, os fenômenos não estão dados. O conceito oposto de "fenômeno" é o conceito de encobrimento. (2015, p. 75/76, itálicos no original).
\end{abstract}

Em resumo, e retomando a definição exposta na primeira citação: a fenomenologia é o deixar e fazer ver por si mesmo o ser do ente, tal como se mostra a partir de si mesmo. É a fenomenologia a responsável por desvelar esse fenômeno que, por poder se velar, justifica a necessidade da fenomenologia como a ciência que promove sua descrição e demonstração.

O ente - que não é o objeto da fenomenologia, mas cujo ser é questionado pela fenomenologia - é esclarecido do seguinte modo por Heidegger:

Como ser constitui o questionado e ser diz sempre ser de um ente, o que resulta como interrogado na questão do ser é o próprio ente. Este é como que interrogado em seu ser. Mas para se poder apreender sem falsificações os caracteres de seu ser, o ente já deve se ter feito acessível antes, tal como é em si mesmo. Quanto ao interrogado, a questão de ser exige que se conquiste e assegure previamente um modo adequado de acesso ao ente. Chamamos de "ente" muitas coisas e em sentidos diversos. Ente é tudo de que falamos dessa ou daquela maneira, ente é também o que e como nós mesmos somos. (2015, p. 42, itálicos no original).

\footnotetext{
${ }^{5}$ Convém ler novamente o último período da citação feita entre as páginas 23/24: "Considerado formalmente, o significado do conceito formal e vulgar de fenômeno legitima a denominação de fenomenologia a toda demonstração de um ente tal como se mostra em si mesmo." (2015, p. 74).
} 
Se o ente "é tudo que falamos dessa ou daquela maneira" e, enquanto interrogado, é sempre questionado em seu modo de ser pela fenomenologia, é possível defini-lo também como tudo que possa ocupar a posição sintáxica de sujeito numa frase com verbo de ligação - tudo que pode ser de algum modo, é um ente. E é esse o motivo por que o ente já deve ter sempre se mostrado em si mesmo para que a fenomenologia possa apreender o mostrar-se em si mesmo do ser desse ente. $\mathrm{O}$ "ser é sempre ser de um ente”, e só é possível questionar o ser de algo que já se mostrou e, assim, tornou-se acessível em seu ser.

Em sentido fenomenológico, fenômeno é somente o que constitui o ser, e ser é sempre ser de um ente. Por isso, ao se visar a uma liberação do ser, deve-se, preliminarmente, aduzir de modo devido o próprio ente. Este ente também deve mostrar-se no modo de acesso que genuinamente lhe pertence. E, deste modo, o conceito vulgar de fenômeno torna-se fenomenologicamente relevante. A tarefa preliminar de assegurar "fenomenologicamente" o acesso ao ente exemplar como ponto de partida da própria analítica já se acha sempre delineada a partir da própria meta. $(2015$, p. 77$)$.

Enfim, a fenomenologia, segundo Heidegger, é o deixar e fazer ver por si mesmo o ser do ente, tal como se mostra a partir de si mesmo. O ente é tudo que possui um modo de ser; e o ser é esse modo, esse como que constitui o fenômeno cujo sentido a fenomenologia busca desvelar para descrever e demonstrar. 


\section{Capítulo 5. Uma fenomenologia da língua e do signo linguístico no estruturalismo linguístico.}

A fenomenologia foi definida no capítulo anterior como o deixar e fazer ver por si mesmo o ser do ente, tal como se mostra a partir de si mesmo. É diante dessa definição que se pode imaginar uma fenomenologia da língua e do signo linguístico. Essa fenomenologia seria o deixar e fazer ver por si mesmo o ser da língua, tal como se mostra a partir de si mesmo, e o deixar e fazer ver por si mesmo o ser do signo linguístico, tal como se mostra a partir de si

mesmo. É necessário, portanto, compreender a língua e o signo linguístico como entes, isto é, como coisas que possuem, cada uma, um modo de ser que se mostra em si mesmo e que, por esse motivo, podem ser questionados, apreendidos e explicados por uma fenomenologia.

Mas imaginar uma fenomenologia possível é só o primeiro passo para demonstrar sua possibilidade. Uma forma de demonstrá-la seria realizá-la de fato. O que poderia ser mais demonstrativo da factibilidade de uma fenomenologia que sua realização? Entretanto, aqui não realizarei uma tal fenomenologia da língua e do signo linguístico. E o determinante motivo dessa abstenção já foi informado nos primórdios dessa introdução: não pude acessar diretamente a língua e o signo linguístico; não pude, e provavelmente ainda nem poderia, apreendê-los e analisá-los por conta própria. O que pude foi acessá-los indiretamente através das interpretações que encontrei nos autores selecionados.

Como então demonstrar a possibilidade de uma fenomenologia da língua e do signo linguístico? O caminho que escolhi para alcançar essa demonstração foi tentar identificar uma relação entre a fenomenologia, de um lado, e o estruturalismo linguístico, de outro. Antes, porém, de apresentar esse caminho, considero necessário relembrar alguns pontos sobre o estruturalismo linguístico.

O estruturalismo linguístico foi definido como uma postura metodológica que caracteriza um conjunto de pesquisas e estudos realizados na área da Linguística. Como metodologia, o estruturalismo linguístico se distingue e se caracteriza por conta da intenção de compreender e explicar seus objetos através da projeção de um modelo de estrutura (ou modelo estrutural) sobre esses objetos; ou seja, é a intenção de compreendê-los e explicá-los como se fossem estruturas correspondentes a um modelo de estrutura pré-estabelecido. Esperando não ser tão repetitivo, vejamos o que pode ser extraído dessa caracterização.

A metodologia que é o estruturalismo linguístico parece poder ser explicada em três etapas. Num primeiro momento, formula-se um modelo de estrutura de caráter geral e hipotético. Geral, pois pode ser aplicado a qualquer objeto que se deseje analisar; hipotético, 
pois não constitui um axioma (dogma), mas uma forma artificial cuja validade depende de sua efetividade e adequação explicativa. Num segundo momento, esse modelo de estrutura previamente formulado é projetado sobre o objeto que se pretende analisar. E, num terceiro momento, busca-se explicar o objeto analisado a partir da projeção do modelo de estrutura, como se o objeto analisado fosse estruturado de forma correspondente ao modelo projetado.

Essa decomposição em três etapas revela que não há no estruturalismo linguístico um questionamento ontológico. Isto é, não se propõe como questão a natureza ou a essência do objeto que estuda - não se preocupa com o que é ou com o como é, com o objeto em si. Denomina-se estruturalismo porque vale-se de um modelo de estrutura que é externo ao objeto para analisá-lo, e não porque busca desvendar no objeto uma estrutura que lhe seja interna ou natural - algo que sequer cogita fazer. Na verdade, o estruturalismo linguístico assumidamente esforça-se para evitar quaisquer considerações de caráter ontológico ("filosófico" ou "metafísico"), o que fica claro no seguinte trecho de Hjelmslev:

\footnotetext{
Isenta de todo dogmatismo, a linguística estrutural, por conseguinte, abstém-se igualmente de qualquer especulação metafísica, bem como das apreciações subjetivas de uma estética vaga e estéril. A linguística estrutural substituirá a filosofia da linguagem de outrora por uma pesquisa positiva e científica.

Acrescentemos desde já que a pesquisa assim considerada não está por isso limitada ao detalhe ou ao particular. Pelo contrário, dirige-se ao geral. A hipótese inicial, como se poderá observar, não se pronuncia sobre a "natureza" do "objeto" estudado. Evita perder-se numa metafísica ou numa filosofia do Ding an sich. Dirige-se unicamente ao método. É verdade que o "método cientificamente legítimo" se resume, em última análise, ao método empiricamente adequado. Desse modo, a hipótese inicial faz profissão do empirismo; mas para uma hipótese técnica é útil escolher uma fórmula que não leve à obrigação epistemológica de definir o empirismo, tarefa que ultrapassa largamente os limites de nossa disciplina e é de alçada da teoria do conhecimento. É, pois, somente o método que está em causa, e o que a pesquisa é chamada a controlar é a possibilidade do método preconizado pela hipótese.

Desses fatos podemos agora extrair algumas diretivas que devem ser observadas por um órgão consagrado à linguística estrutural:

Esse órgão está a serviço de uma hipótese e de uma pesquisa voltadas para um princípio.

Exclui o dogmatismo apriorístico, que se subtrai ao controle científico e não se funda em fatos bem expostos. Exclui outrossim os fatos que não se prestam a ilustrar, de maneira positiva ou negativa, a utilidade do método estrutural. Portanto, exclui também as generalidades nitidamente filosóficas e as especialidades estudadas por si mesma. Sua tarefa será a de descortinar o geral no particular e o particular no geral. (1991, p. 30/31, itálicos no original).
}

Não há, portanto, no estruturalismo linguístico, qualquer intenção ontológica; pelo contrário, o que há é a intenção de esquivar-se de qualquer questionamento ontológico e, consequentemente, fenomenológico. 
Como, então, pude pretender identificar uma relação entre o estruturalismo linguístico e a fenomenologia? Em outros termos, como pude pretender identificar uma relação entre o estruturalismo linguístico e algo com que expressamente não quer se relacionar? E como essa relação praticamente impossível poderia demonstrar a possibilidade de uma fenomenologia da língua e do signo linguístico?

Fi-lo porque acreditava que as obras dos autores selecionados apresentavam algo além dos resultados decorrentes da aplicação da metodologia estruturalista; apresentavam algo sobre a língua e o signo linguístico compreendidos em si mesmos. E acredito que encontrei considerações de caráter fenomenológico acerca da língua e do signo linguístico em todas as obras dos autores selecionados (Saussure, Hjelmslev, Barthes, Eco e Blikstein). Ou seja, em meio às interpretações obtidas a partir da aplicação da metodologia estruturalista, foi possível encontrar lampejos de interpretações fenomenológicas, interpretações sobre o modo de ser da língua e do signo linguístico. Não obstante, apesar de crer no que encontrei, tenho consciência de que minha crença talvez não seja nada além de um delírio.

Mas o que esse delírio poderia significar se não fosse um delírio? Pode significar que em toda e qualquer análise de um objeto (de um ente), sempre já há uma prévia interpretação de ser, ainda que conscientemente se queira afastar qualquer interpretação de ser. É o que Heidegger afirma, por exemplo, quando cita a seguinte frase de Tomás de Aquino: "Uma compreensão de ser já está sempre incluída em tudo que se apreende no ente" $(2015$, p. 38). Ou seja, por mais que o estruturalismo linguístico se esforce por excluir interpretações fenomenológicas, elas já estão sempre incluídas em todas as outras interpretações que se esforça para realizar.

Eis aqui o caminho que escolhi para demonstrar a possibilidade de uma fenomenologia da língua e do signo linguístico: relatar as interpretações de caráter fenomenológico que consegui constatar no interior do estruturalismo linguístico. Afinal, se é possível identificar uma fenomenologia da língua e do signo linguístico inconscientemente realizada no interior do estruturalismo linguístico, é certamente possível, de algum modo, realizá-la conscientemente.

Os capítulos da parte II a seguir trarão as interpretações fenomenológicas que encontrei nas obras de cada um dos autores selecionados. 


\section{PARTE II}

UMA FENOMENOLOGIA DA LÍNGUA E DO SIGNO LINGUÍSTICO

Uma fenomenologia no estruturalismo 


\title{
Capítulo 1. Ferdinand de Saussure.
}

\begin{abstract}
Cumpre notar que definimos as coisas, e não os termos; as distinções estabelecidas nada têm a recear, portanto, de certos termos ambíguos, que não têm correspondência entre duas línguas. Assim, em alemão, Sprache quer dizer "língua" e "linguagem"; Rede corresponde aproximadamente a "palavra", mas acrescentando-lhe o sentido especial de "discurso". Em latim, sermo significa antes "linguagem" e "fala", enquanto lingua significa a língua, e assim por diante. Nenhum termo corresponde exatamente a uma das noções fixadas; eis por que toda definição a propósito de um termo é vã; é um mau método partir dos termos para definir as coisas. (2012A, p. $45 / 46$, itálicos no original).
\end{abstract}

\section{a) Preliminarmente}

Dentre todos os "preliminarmente", este será o menor em palavras, mas o maior em sentimento. Saussure foi meu primeiro contato com a linguística. Alguém quase intocável por entre anotações de aula e escritos esparsos e muitas vezes incompletos... foi capaz de me tocar de forma permanente. Ao fazê-lo, mudou minha forma de viver o mundo, minha vida e quem eu sou. Muito obrigado, Saussure.

\section{b) A língua}

É curioso notar como Saussure define a língua de forma fragmentada; isto é, apresenta a seu leitor definições parciais que, não exclusivas, são unificáveis numa única definição. Por exemplo, não se fatiga de constantemente afirmar que a língua é uma espécie de convenção social, uma instituição humana. Por outro lado, relaciona-a a uma das formas do multiforme fenômeno da linguagem humana, além de também defini-la como um sistema de signos. A aglutinação dos três fragmentos resulta em: a língua é um sistema de signos fixados por uma convenção social e constitui uma das formas de manifestação da linguagem humana.

Saussure começa a definir a língua relacionando-a à linguagem humana e buscando diferenciá-las. A língua não se confunde com a linguagem, apesar de com ela relacionar-se intimamente. E a relação que mantêm entre si é resumível pelo binômio continente/conteúdo: a linguagem humana contém a língua, que, assim, compõe uma de suas formas de manifestação.

A linguagem humana destaca-se por sua multiformidade, que a torna praticamente indelineável, indefinível, pois não unificável. 
Tomada em seu todo, a linguagem é multiforme e heteróclita; o cavaleiro de diferentes domínios, ao mesmo tempo física, fisiológica e psíquica, ela pertence além disso ao domínio individual e ao domínio social; não se deixa classificar em nenhuma categoria de fatos humanos, pois não se sabe como inferir sua unidade. (2012A, p. 41).

Quando se manifesta, a linguagem humana apresenta-se sob três distintas formas: uma psíquica, uma fisiológica e outra física. Para ilustrar, basta imaginar alguém que se comunica através de um ato de fonação e, portanto, manifesta-se enquanto manifesta a linguagem humana a outrem que executa um ato de audição. A forma psíquica ocorre, segundo Saussure, no cérebro, por meio da identificação de uma imagem acústica adequada para exprimir o conceito ${ }^{6}$ que se pretende expressar a alguém através do ato de fonação; e, também no cérebro, com a associação da imagem acústica recebida pelo aparelho auditivo ao conceito que lhe corresponda. A forma fisiológica ocorre na fonação após a associação do conceito à imagem acústica adequada para exprimi-la, quando então o cérebro determina que o aparelho fonador realize a imagem acústica emitindo um som a ela relativo. Já na audição, a forma fisiológica resume-se na tradução do som recebido numa imagem acústica, que será a seguir enviada ao cérebro para que ocorra a forma psíquica. Por fim, Saussure indica a forma física de manifestação da linguagem humana, que corresponde à propagação da imagem acústica, realizada pelo aparelho fonador, através de ondas sonoras até o aparelho auditivo de alguém.

A multiformidade é um dos motivos que leva Saussure a atribuir à linguagem humana o adjetivo "heteróclita". O outro motivo é o fato de a linguagem humana pertencer simultaneamente a um domínio individual e a um domínio social. Por domínio pode-se entender uma espacialidade onde a linguagem humana é manifestável. Assim, a oposição de domínios individual/social é pensada por Saussure como os dois ambientes possíveis de manifestação da linguagem humana. No ambiente individual, a linguagem manifesta-se através dos indivíduos que falam, manifestando-a. No ambiente social, a linguagem manifesta-se através de uma convenção firmada por um corpo social e adquire caráter de instituição. Ao domínio individual, Saussure atribui o nome de "fala" e, ao social, o nome de "língua" - eis aqui um dos fragmentos da definição. A fala e a língua são os dois componentes da linguagem humana.

\footnotetext{
${ }^{6}$ Os conceitos "imagem acústica" e "conceito" serão esclarecidos mais adiante, quando falarei especificamente do signo linguístico como definido por Saussure.
} 
O estudo da linguagem comporta, portanto, duas partes: uma, essencial, tem por objeto a língua, que é social em sua essência e independente do indivíduo - esse estudo é unicamente psíquico; outra, secundária, tem por objeto a parte individual da linguagem, vale dizer, a fala, inclusive a fonação - é psicofísica. (2012A, p. 51).

A fala é essencialmente individual e o lugar de sua realização é o indivíduo que fala a linguagem humana. A fala é uma função do falante. É o indivíduo, e apenas ele, que seleciona as imagens acústicas existentes no sistema da língua e as encadeia para expressar as ideias que pretende exprimir. Tanto a forma psíquica quanto a forma fisiológica de manifestação da linguagem humana dependem exclusivamente da ação do indivíduo que fala e que, com isso, associa conceitos a imagens acústicas e exprime-as através de seu aparelho fonador. "A parte psíquica não entra tampouco totalmente em jogo: o lado executivo fica de fora, pois a sua execução jamais é feita pela massa; é sempre individual e dela o indivíduo é sempre senhor; nós a chamaremos fala (parole)." (2012A, p. 45, itálicos no original)

Em oposição à fala como uma individualidade do indivíduo falante, Saussure propõe a língua como o resultado de uma convenção social. "Ela é a parte social da linguagem, exterior ao indivíduo, que, por si só, não pode nem criá-la nem modificá-la; ela não existe senão em virtude de uma espécie de contrato estabelecido entre os membros da comunidade.” (2012A, p. 46). A convenção social é o conjunto (ou a soma) dos elementos linguísticos que cada falante de uma língua possui em seu cérebro. Somados, todos os falantes, ou todos os cérebros que guardam frações da convenção, ou ainda melhor, todas as frações que existem em seus cérebros, formam a convenção em sua totalidade, o conjunto total de regras gramaticais, conceitos e imagens acústicas existentes na língua - a língua em si. A língua, por conseguinte, como proposta por Saussure, é a somatória de todos esses elementos convencionados socialmente e depositados de forma pulverizada no cérebro de cada um de seus falantes.

Se pudéssemos abarcar a totalidade das imagens verbais armazenadas em todos os indivíduos, atingiríamos o liame social que constitui a língua. Trata-se de um tesouro depositado pela prática da fala por todos os indivíduos pertencentes à mesma comunidade, um sistema gramatical que existe virtualmente em cada cérebro ou, mais exatamente, nos cérebros dum conjunto de indivíduos, pois a língua não está completa em nenhum, e só na massa ela existe de modo completo. (2012A, p. 45).

A língua existe na coletividade sob a forma de uma soma de sinais depositados em cada cérebro, mais ou menos como um dicionário cujos exemplares, todos idênticos, fossem repartidos entre os indivíduos (ver p. 45). Trata-se de algo que está em cada um deles, embora seja comum a todos e independa da vontade do depositário. (2012A, p. 51). 
Logo, a língua, ao contrário da fala, não é uma função do indivíduo, que não pode criála ou modificá-la. O contato que mantém com a língua é definido por Saussure como passivo, afinal, “A língua não constitui, pois, uma função do falante: é o produto que o indivíduo registra passivamente; não supõe jamais premeditação..." (2012A, p. 45). Cada indivíduo apreende a língua através do uso e da imersão em seu ambiente de uso; e a apreensão é o aprendizado e o registro do sistema linguístico convencionado pela coletividade.

Retomando a atenção à linguagem humana e sua multiformidade, é possível agora identificar de forma mais eficaz a língua e a fala, bem como demonstrar sua inter-relação. A fala em sua individualidade é a associação dum conceito a uma imagem acústica adequada para exprimi-lo, seguida pela fonação do som correspondente à imagem acústica. Não é demais lembrar que a associação e a fonação são realizadas, respectivamente, no cérebro e no aparelho fonador de um indivíduo qualquer. Contudo, a associação psíquica do conceito à imagem acústica, apesar de individual, fundamenta-se na língua, em seu sistema, como convencionado pela coletividade. Em outros termos um pouco mais elucidativos: o indivíduo é capaz de decidir o que quer exprimir (qual conceito quer manifestar), mas, uma vez decidido, deverá necessariamente exprimi-lo através da imagem acústica que a língua a ele relacionou. Ou seja, associar é identificar no interior do sistema linguístico qual a imagem acústica adequada para expressar o conceito que se quer expressar.

\begin{abstract}
A fala é, ao contrário, um ato individual de vontade e inteligência, no qual convém distinguir: $1^{\circ}$ - as combinações pelas quais o falante realiza o código da língua no propósito de exprimir seu pensamento pessoal; $2^{\circ}$ - o mecanismo psicofísico que lhe permite exteriorizar essas combinações. (2012A, p. 45).
\end{abstract}

Com isso, a língua, enquanto convenção social de caráter sistemático, viabiliza, pois instrumentaliza, o exercício da forma psicofísica de manifestação da linguagem humana e permite que a fala seja articulada. Entretanto, se a fala depende da língua para instrumentalizarse, há ainda uma dependência inversa, igualmente importante: a língua depende da fala para estabelecer-se no tempo.

Sem dúvida, esses dois objetos estão estritamente ligados e se implicam mutuamente; a língua é necessária para que a fala seja inteligível e produza todos os seus efeitos; 
mas esta é necessária para que a língua se estabeleça; historicamente, o fato da fala vem sempre antes. Como se imaginaria associar uma ideia a uma imagem verbal se não se surpreendesse de início essa associação num ato de fala? (...). Enfim, é a fala que faz evoluir a língua: são as impressões recebidas ao ouvir os outros que modificam nossos hábitos linguísticos. Existe, pois, interdependência da língua e da fala; aquela é ao mesmo tempo o instrumento e o produto desta. Tudo isso, porém, não impede que sejam duas coisas absolutamente distintas. (2012A, p. 51, itálicos meus).

Ora, se até então, como expus, Saussure definiu a fala como o domínio individual da linguagem humana, o local onde reina a idiossincrasia de cada falante, não seria um paradoxo submeter a língua, definida como uma convenção social, à fala? Creio que não, desde que consideremos que por "fala", neste caso, Saussure quis referir-se ao conjunto das falas executadas pela coletividade que fala segundo a língua, e não a um ou alguns poucos atos individuais de fala. $\mathrm{O}$ que permite que a língua se mantenha no tempo é a continuidade da fala social, da fala em conjunto dos indivíduos falantes. E essa interpretação é permitida pelo parágrafo que inicia logo a página seguinte:

De que maneira a fala está presente nessa mesma coletividade? É a soma do que as pessoas dizem e compreende: a) combinações individuais, dependentes da vontade dos que falam; b) atos de fonação igualmente voluntários, necessários para a execução dessas combinações. (2012A, p. 52, itálicos meus).

A soma da fala de todos os indivíduos que falam projeta a imagem da fala individual na coletividade, criando uma espécie de ente coletivo que fala, fala uma mesma língua, associa conceitos e imagens acústicas contempladas pelo sistema duma mesma língua. Assim, para manter-se enquanto convenção social, a língua precisa ser e continuar a ser falada pelo corpo social. Convencionar o sistema de uma língua é então não apenas iniciar a falá-lo, mas permanecer falando-o.

Com isso, Saussure afirma que a língua enquanto convenção supera e ultrapassa a esfera individual (onde seria compreendida somente como o sistema que permite que os indivíduos falem através da associação de conceitos a imagens acústicas) e projeta-se à esfera social (a esfera que confere suporte para a existência da língua enquanto a fala continuamente). A essa esfera social, que fala a língua continuamente assegurando sua existência como convenção social, Saussure confere a denominação de "massa falante". 
Mas essa definição deixa a língua ainda fora de sua realidade social; faz dela uma coisa irreal, pois não abrange mais que um dos aspectos da realidade: o individual; é mister uma massa falante para que exista uma língua. Em momento nenhum, e contrariamente à aparência, a língua existe fora do fato social, visto ser um fenômeno semiológico. (2012A, p. 117/118, itálicos no original)

E a dependência que mantém relativamente à continuidade da fala da massa falante para preservar sua existência revela ainda um outro caráter da língua: sua temporalidade. A língua é temporal porque existe e continua existindo no tempo enquanto é falada pela massa falante - é e está no tempo; mas também é temporal porque secciona o tempo, ainda que fortuitamente, ou não-intencionalmente, de acordo com as modificações que sofre com o passar do tempo - possui seu próprio tempo ${ }^{7}$. Enquanto situada no tempo, a língua é histórica, evolui com a passagem do tempo e apresenta-se para cada geração que a fala como uma herança de épocas passadas.

\begin{abstract}
A qualquer época que remontemos, por mais antiga que seja, a língua aparece sempre como uma herança da época precedente. $\mathrm{O}$ ato pelo qual, em dado momento, os nomes teriam sido distribuídos às coisas, pelo qual um contrato teria sido estabelecido entre os conceitos e as imagens acústicas - esse ato podemos imaginá-lo, mas ele jamais foi comprovado.

(...).

De fato, nenhuma sociedade conhece nem jamais conheceu a língua de outro modo que não fosse como um produto herdado de gerações anteriores e que cumpre receber como tal. Eis por que a questão da origem da linguagem não tem a importância que geralmente se lhe atribui. (2012A, p. 112).
\end{abstract}

Enquanto demarca o tempo a seu modo, a língua se mantém enquanto se altera - frase que certamente soa um tanto paradoxal, pois, como a língua poderia se manter enquanto se altera? Ora, se ela se altera não é porque não se mantém? A resposta pode parecer mais simples do que de fato é: a língua nunca se altera em seu todo, sempre preserva o núcleo fundamental de seu sistema. Isto é, as alterações que a língua sofre com o passar do tempo não são jamais gerais e repentinas, mas especificíssimas e demoradas: "Por fim, voltando à língua, perguntarse-á por que o fator histórico da transmissão a domina totalmente e exclui toda transformação linguística geral e repentina.” (2012A, p. 112). À capacidade de manutenção apresentada pela

\footnotetext{
${ }^{7}$ Convém comentar que há duas temporalidades que qualificam a língua: a que será tratada agora, criada pela sucessão de diacronias no tempo, e a que será tratada mais adiante, criada pela sucessão linear de significantes na cadeia da fala (sintagma)
} 
língua, Saussure atribui o nome de "imutabilidade" e à possibilidade de alteração, o nome de "mutabilidade".

Sobre a imutabilidade, Saussure lista algumas justificativas ou fatores de conservação, dos quais tratarei de um, o que é pertinente para a presente abordagem: a tradição ou caráter hereditário da língua ${ }^{8}$. Vejamos. A língua apresenta-se a cada geração como um legado de gerações passadas, ou seja, como algo dado. $\mathrm{O}$ fato de ser dado influencia psicologicamente seu uso e aquieta anseios de alteração. Como dado, a língua deve ser aprendida e utilizada, ações que não exigem qualquer consciência sobre suas estruturas, sobre seu funcionamento. Ainda, por ser falada por todos, mostra-se suficiente, não despertando qualquer senso crítico que intencionasse sua alteração; pelo contrário, enseja o sentimento espontâneo de tradição, de respeito ao que sempre foi falado e como foi falado. Logo, as próprias forças sociais, a própria massa falante que continua falando a mesma língua desde o passado e em direção ao futuro, atuam como um fator de preservação.

Cumprirá acrescentar, ainda, que a reflexão não intervém na prática de um idioma; que os indivíduos, em larga medida, não têm consciência das leis da língua; e, se não as percebem, como poderiam modificá-las? Ainda que delas tivessem consciência, é preciso lembrar que os fatos linguísticos não provocam a crítica, no sentido de que cada povo geralmente está satisfeito com a língua que recebeu. (2012A, p. 113).

Não basta, todavia, dizer que a língua é um produto de forças sociais para que se veja claramente que não é livre; a par de lembrar que constitui sempre herança de uma época precedente, deve-se acrescentar que essas forças sociais atuam em função do tempo. Se a língua tem um caráter de fixidez, não é somente porque está ligada ao peso da coletividade, mas também porque está situada no tempo. Ambos os fatos são inseparáveis. A todo instante a solidariedade com o passado põe em xeque a liberdade de escolher. Dizemos homem e cachorro porque antes de nós se disse homem e cachorro. (2012A, p. 114).

Se o sistema jamais poderá ser modificado drasticamente, como se dá a mutação? As alterações são sempre provocadas pelo uso da língua, pela fala. Germinam na individualidade da fala e propagam-se vagarosamente em direção à massa falante: "É na fala que se acha o germe de todas as modificações: cada uma delas é lançada, a princípio, por certo número de indivíduos, antes de entrar em uso.” (2012A, p. 141). Somente seu uso massivo é capaz de

\footnotetext{
${ }^{8}$ Um dos outros fatores é a arbitrariedade do signo linguístico, que será tratada no tópico especialmente dedicado a esse ente. Os outros três (a resistência da inércia coletiva a toda renovação linguística, a multidão de signos que compõem o sistema e a complexidade do sistema) não serão tratados, pois pouco desenvolvidos por Saussure e não tão relevantes à compreensão do tema da imutabilidade - e não é demais dizer que são fatores secundários, ou seja, não subsistiriam caso algum dos fatores primários não existisse.
} 
provocar alterações no sistema da língua. Assim, essas alterações - que são sempre marginais e atingem apenas elementos isolados - só adquirem eficácia quando finalmente são acatadas pela massa falante.

\begin{abstract}
Um fato de evolução é sempre precedido de um fato, ou melhor, de uma multidão de fatos similares na esfera da fala; isso em nada debilita a distinção estabelecida anteriormente; esta se acha inclusive confirmada, pois na história de toda inovação encontram-se sempre dois momentos distintos: $1^{\circ}$ - aquele em que ela surge entre os indivíduos; $2^{\circ}$ - aquele em que se tornou um fato de língua, exteriormente idêntico, mas adotado pela comunidade. (2012A, p. 141).
\end{abstract}

Contudo, mesmo depois de acatadas, e apesar de repercutirem no sistema em diferentes graus, não formam sistema entre si, como destaca Saussure: "Dessarte, os fatos diacrônicos são particulares; a modificação de um sistema se faz pela ação de acontecimentos que não apenas lhe são estranhos, como também isolados, sem formar sistema entre si." (2012A, p. 137). Portanto, tanto a imutabilidade quanto a mutabilidade são resultantes das ações que a massa falante exerce, inconscientemente, sobre a língua no do tempo.

\footnotetext{
A língua já não é agora livre, porque o tempo permitirá às forças sociais que atuam sobre ela desenvolver seus efeitos, e chega-se assim ao princípio da continuidade, que anula a liberdade. A continuidade, porém, implica necessariamente a alteração, o deslocamento mais ou menos considerável das relações. (2012A, p. 119).
}

A massa falante inconscientemente mantém-se falando o que sempre se falou e, também inconscientemente, fala a seu modo o que até então se falava de outro modo. E é esse jogo existente entre a mutabilidade e a imutabilidade que permite que a língua possua seu próprio tempo. O tempo da língua é representado pelo encadeamento de manutenções e mutações, que forma um enredo em que se sucedem estados. Os estados são denominados por Saussure de "sincronias" e representam sistemas linguísticos plenos, cujos elementos são solidários e coexistentes em determinado intervalo de tempo. A alteração em qualquer elemento de uma sincronia promove sua substituição por uma nova sincronia. A passagem entre sincronias representa uma fase evolutiva e a ela Saussure atribuiu o nome de "diacronia": "É sincrônico tudo quanto se relacione com o aspecto estático da nossa ciência, diacrônico tudo 
que diz respeito às evoluções. Do mesmo modo, sincronia e diacronia designarão respectivamente um estado de língua e uma fase da evolução." (2012A, p. 123).

É a substituição de uma sincronia por outra, através da intermediação de uma diacronia, que marca a segmentação do tempo pela língua. Cada diacronia é uma nova segmentação do tempo que permite, por exemplo, identificar até quando um termo que não é mais falado foi falado.

Se as sincronias ilustram sistemas linguísticos que se substituem no tempo, as diacronias, que não formam sistema entre si, são conjuntos de acontecimentos que provocam tais substituições. Os acontecimentos marcam relações entre elementos substituídos, na sincronia passada, e elementos substitutos, da sincronia futura. Como as diacronias não são sistemas, Saussure faz o seguinte alerta para o linguista que pretende dedicar-se à análise diacrônica da língua: “(...) se este se coloca na perspectiva diacrônica, não é mais a língua o que percebe, mas uma série de acontecimentos que a modificam." (2012A, p. 132). Diante disso, e porque a língua, ao lado do signo linguístico, constitui o objeto primordial de minha pesquisa, não mais me aprofundarei no tema das diacronias, mas apenas no tema das sincronias - por opção metodológica e, por certo, economia. Considero, entretanto, que o tema das diacronias foi suficientemente manejado e cumpriu a finalidade que lhe propus - auxiliar na ilustração da temporalidade da língua, uma de suas características fenomenológicas constatadas por Saussure.

O enfoque sincrônico, que será tratado a partir de agora, além de ressaltar seu caráter sistemático, tem o condão de revelar outra característica fenomenológica da língua. Como definida, a sincronia é o intervalo em que o sistema linguístico convencionado pela massa falante continua sendo por ela falado sem sofrer qualquer alteração que lhe seja relevante.

\footnotetext{
Na prática, um estado de língua não é um ponto, mas um espaço de tempo, mais ou menos longo, durante o qual a soma das modificações ocorridas é mínima. Pode ser de 10 anos, uma geração, um século e até mais. Uma língua mudará pouco durante um longo intervalo, para sofrer, em seguida, transformações consideráveis em alguns anos. (2012A, p. 146).
}

E enquanto permanece continuamente falada, a língua (a sincronia vigente) constitui a única realidade para massa a falante: "Neste ponto, está claro que o aspecto sincrônico prevalece sobre o outro, pois, para a massa falante, ele constitui a verdadeira e única realidade (ver p. 123).” (2012A, p. 132, itálicos meus). Consequentemente, se estudar a língua 
sincronicamente é investigar seu sistema e seu funcionamento através do testemunho daqueles que a falam, é também investigar o que há de real e o que é real para aqueles que a falam. $\mathrm{O}$ que há e o que é.... é o retrato da língua no intervalo de uma sincronia.

\begin{abstract}
A sincronia conhece somente uma perspectiva, a das pessoas que falam, e todo o seu método consiste em recolher-lhes o testemunho; para saber em que medida uma coisa é uma realidade, será necessário e suficiente averiguar em que medida ela existe para a consciência de tais pessoas." (2012A, p. 132).
\end{abstract}

Essa é a interpretação fenomenológica da língua que encontrei em Saussure: a língua $e ́$ a verdadeira e única realidade para a massa falante. O modo de ser da língua mostra-se em si mesmo como ser-a-realidade ou ser-o-real. Em outros termos, sendo, a língua mostra-se em seu modo de ser como a realidade.

E esse modo de ser acarreta uma importante consequência ontológica também notada por Saussure. Ser-a-realidade é ser tudo aquilo que é real, tudo aquilo que, na realidade, existe. Assim, se existir é ser-real, e ser-real é ser-na-realidade, logo, existir é o mesmo que ser-nalíngua, pois a língua é a realidade. A língua é onde se existe, é onde se é real, é onde se pode ser. Por esse motivo, Saussure afirma que "para saber em que medida uma coisa é uma realidade, será necessário e suficiente averiguar em que medida ela existe para a consciência de tais pessoas", porque, para tais pessoas, que são a massa falante, a língua mostra-se em seu modo de ser como a única e verdadeira realidade.

Mas há ainda o que comentar sobre a língua, ainda que não mais em caráter fenomenológico. A perspectiva sincrônica, porque se refere a um estado estabilizado no tempo, além de permitir a interpretação de caráter fenomenológico acima mostrada, também permitiu a Saussure analisar a língua como um sistema. A análise sistemática leva em conta os elementos constitutivos do sistema e as relações que estes mantêm entre si: "A Linguística sincrônica se ocupará das relações lógicas e psicológicas que unem os termos coexistentes e que formam sistemas, tais como são percebidos pela consciência coletiva.” (2012A, p. 142).

Assim, a língua, enquanto sistema, apresenta-se como uma ordem de $\operatorname{signos}^{9}$ (o terceiro fragmento da definição fragmentada proposta por Saussure), cujas relações são regidas

\footnotetext{
${ }^{9}$ Os signos linguísticos são, resumidamente, a união entre um conceito e uma imagem acústica. Serão tratados com maior afinco logo abaixo, em tópico próprio. Por ora, deixo a seguinte citação: "Enquanto a linguagem é heterogênea, a língua assim delimitada é de natureza homogênea: constitui-se num sistema de signos em que, de essencial, só existe a união do sentido e da imagem acústica, e em que as duas partes do signo são igualmente psíquicas." (2012A, p. 46).
} 
por regras gerais de caráter semiológico. Por ser sistema, é possível distinguir o que lhe é interno do que lhe é externo segundo um critério elaborado por Saussure: será interno tudo que, quando alterado, provoque uma alteração do sistema em qualquer medida. E, pelo contrário, logicamente, será externo tudo que, quando alterado, não seja capaz de provocar qualquer alteração no sistema.

Não é menos verdade que certa atenção se faz necessária para estabelecer distinções dessa espécie. Assim, em cada caso, formular-se-á a questão da natureza do fenômeno, e, para resolvê-la, observar-se-á esta regra: é interno tudo quanto provoca mudança do sistema em qualquer grau. (2012A, p. 56).

Destaca-se, assim uma característica marcante do sistema linguístico, que é a autonomia de sua ordem interna. "No que concerne à Linguística interna, as coisas se passam de modo diferente: ela não admite uma disposição qualquer; a língua é um sistema que conhece somente sua ordem própria." (2012A, p. 55). É a língua que define o que é relevante e o que é irrelevante para seu sistema, determinando o que será interno e o que será externo. Tudo que for interno classificar-se-á ou na categoria dos signos ou na categoria das regras gerais; e tudo que for externo terá caráter meramente acidental quando relacionado ao sistema.

Excluindo o que é diacrônico e o que é externo ao sistema linguístico e considerando o que lhe é interno, restam como objeto da Linguística sincrônica as seguintes questões: a questão das entidades concretas, a dos valores e a das relações existentes entre as entidades concretas. Com base no que foi dito até o momento parece fácil presumir que as entidades concretas da língua são, para Saussure, os signos. E é a partir desse ponto que passo ao tópico seguinte, à análise do signo linguístico.

\section{c) E o signo linguístico}

O signo é uma composição elementar binária ou, ilustrativamente, uma espécie de esfera com dois hemisférios bem distintos, porém correlacionados. Os elementos componentes do signo são denominados de imagem acústica e conceito, cujos sinônimos são, respectivamente: significante e significado. 
Propomo-nos a conservar o termo signo para designar o total, e a substituir conceito e imagem acústica respectivamente por significado e significante; esses dois termos têm a vantagem de assinalar a oposição, que os separa, quer entre si, quer do total de que fazem parte. (2012A, p. 107, itálicos no original).

Tanto significante quanto significado, bem como o signo que constituem, não são abstrações, mas entidades reais e concretas da língua: “Os signos de que a língua se compõe não são abstrações, mas objetos reais (ver pp. 46-47); é deles e de suas relações que a Linguística se ocupa; podem ser chamados entidades concretas dessa ciência.” (2012A, p. 147, itálicos no original). Não obstante "concretos", são essencialmente psíquicos, isto é, não possuem existência material: "Vimos na p. 43 s., a propósito do circuito da fala, que os termos implicados no signo linguístico são psíquicos e estão unidos, em nosso cérebro, por um vínculo de associação. Insistamos nesse ponto.” (2012A, p. 106).

O significante é um conjunto de instruções/coordenadas psíquicas ou mentais que permitem a execução da fala e a interpretação dos sons captados pela audição. É importante notar que não se confunde com o som em si, que é a materialização física gerada pelo aparelho fonador após o cérebro processar as instruções que formam o significante.

\footnotetext{
Esta (a imagem acústica: significante) não é o som, coisa puramente física, mas a impressão (empreinte) psíquica desse som, a representação que dele nos dá o testemunho de nossos sentidos; tal imagem é sensorial e, se chegamos a chamá-la "material", é somente nesse sentido, e por oposição ao outro termo da associação, o conceito, geralmente mais abstrato. (Primeira observação entre parênteses inserida por mim), (2012A, p. 106, itálicos no original).
}

Como conjunto de instruções, o significante também permite que o cérebro processe o som captado pelo aparelho auditivo e o correlacione a eventual significado existente na língua. O significante é uma descrição formal que permite, em primeiro lugar, que o cérebro determine ao aparelho fonador a modelagem e a propagação física de uma substância sonora; e, em segundo lugar, que o cérebro interprete a substância sonora captada pelo aparelho auditivo, identificando o significante que permitiu sua modelagem e propagação.

O significado, à semelhança do significante, é também um conjunto de instruções ou coordenadas de caráter psíquico. Mas seu papel é promover o despertar da consciência e ensejar o exercício da imaginação. É com os dados que constituem o significado (ou os significados) 
que o cérebro adquire a capacidade de delinear ideias, tornando-as concretas e compreensíveis, transformando-as em conceitos.

\begin{abstract}
Psicologicamente, abstração feita de sua expressão por meio das palavras, nosso pensamento não passa de uma massa amorfa e indistinta. Filósofos e linguistas sempre concordaram em reconhecer que, sem o recurso dos signos, seríamos incapazes de distinguir duas ideias de modo claro e constante. Tomado em si, o pensamento é como uma nebulosa em que nada está necessariamente delimitado. Não existem ideias preestabelecidas, e nada é distinto antes do aparecimento da língua. (2012A, p. 158).
\end{abstract}

Talvez os parágrafos anteriores tenham transmitido a ideia equivocada de que a língua cria significantes e significados de forma descompromissada para, em algum momento, quem sabe, uni-los para criar signos. Na verdade, segundo Saussure, a delimitação do significante e do significado dá-se no exato momento em que a língua cria o signo. Não há ordem de criação, há simultaneidade: "Podemos, então, representar o fato linguístico em seu conjunto, isto é, a língua, como uma série de subdivisões contíguas marcadas simultaneamente sobre o plano indefinido das ideias confusas $(A)$ e sobre o plano não menos indeterminado dos sons $(B)(\ldots)$.” (2012A, p. 159). E o processo de criação do signo é assim descrito por Saussure:

O papel característico da língua diante do pensamento não é criar um meio fônico material para a expressão das ideias, mas servir de intermediário entre o pensamento e o som, em condições tais que uma união conduza necessariamente a delimitações recíprocas de unidades. O pensamento, caótico por natureza, é forçado a precisar-se ao se decompor. Não há, pois, nem materialização de pensamento, nem espiritualização de sons; trata-se, antes, do fato, de certo modo misterioso, de o 'pensamento-som' implicar divisões e de a língua elaborar unidades constituindo-se entre duas massas amorfas. (2012A, p. 159).

Ou seja, em seu funcionamento - enquanto um sistema autônomo que cria seus próprios elementos para formar sua ordem interna -, a língua situa-se, ilustrativamente, entre uma camada de ideias e outra de sons, ambas não delimitadas previamente, e delimita-as para criar os signos de que se constitui. Cada signo é o resultado da imposição simultânea de uma segmentação na camada disforme das ideias e na camada disforme dos sons; segmentação que ocorre simultaneamente ao seu entrelaçamento, à sua associação. Em outras palavras, segmentação (de significantes e significados) e formação do signo (pela associação de significantes a significados) ocorrem em perfeita isocronia. 
Dizer que as camadas são inicialmente disformes e dizer que a língua lhes impõe uma forma capaz de segmentar significantes e significados equivale a dizer que, antes da língua, não existiam significantes e significados ou, como diz Saussure, ideias e sons. Antes da intervenção da língua, portanto, não existe o que significar nem como significar. Somente a língua faz surgirem os signos, através da congregação de um significante a um significado, função que exerce de forma arbitrária - aqui o princípio da arbitrariedade do signo.

O laço que une o significante ao significado é arbitrário ou então, visto que entendemos por signo o total resultante da associação de um significante com um significado, podemos dizer mais simplesmente: o signo linguístico é arbitrário. (2012A, p. 108, itálicos no original).

O sistema da língua, segundo Saussure, goza de extrema liberdade para delimitar a camada dos sons e a camada das ideias e correlacionar significantes e significados. Como não há ideias e sons pré-existentes, a língua pode formá-los e associá-los arbitrariamente: "Não só os dois domínios ligados pelo fato linguístico são confusos e amorfos, como a escolha que se decide por tal porção acústica para essa ideia é perfeitamente arbitrária.” (2012A, p. 160). Ou seja, a língua pode unir qualquer significante a qualquer significado. Não há significante que atraia para si necessariamente um significado; e a recíproca é uma consequência, não há um significado que necessariamente deva ser significado por um significante: “Assim, a ideia de 'mar' não está ligada por relação alguma interior à sequência de sons $m-a-r$ que lhe serve de significante; poderia ser representada igualmente bem por outra sequência, não importa qual; (...).” (2012A, p. 108). Nada vincula a língua na criação de seus signos, pois nada lhe é préexistente.

Para prevenir equívocos sobre esse princípio, Saussure faz o seguinte alerta:

A palavra arbitrário requer também uma observação. Não deve dar a ideia de que o significado dependa da livre escolha do que fala (ver-se-á, mais adiante, que não está ao alcance do indivíduo trocar coisa alguma num signo, uma vez que esteja ele estabelecido num grupo linguístico); queremos dizer que o significante é imotivado, isto é, arbitrário em relação ao significado, com o qual não tem laço natural na realidade. (2012A, p. 109, itálicos no original). 
A observação de Saussure é certeira e se coaduna com a definição convencional que confere à língua. Como convenção social, somente a coletividade (massa falante) é capaz de, eventualmente e após um longo período de tempo (uma diacronia), ocasionar alguma mutação no sistema linguístico (o que inclui a relação entre o significante e o significado de um ou mais signos). Por conseguinte, o princípio da arbitrariedade funciona como um fator de conservação (imutabilidade) do sistema linguístico. Como o vínculo entre significante e significado é arbitrário, ou seja, não há um motivo que motive tal associação, não há razão para discutir a substituição ou a alteração de um significante para um significado ou, reciprocamente, de um significado para um significante. A arbitrariedade sossega qualquer anseio de alteração.

\begin{abstract}
Vimos que o caráter arbitrário do signo nos fazia admitir a possibilidade teórica de mudança; aprofundando a questão, vemos que, de fato, a própria arbitrariedade do signo põe a língua ao abrigo de toda tentativa que vise a modificá-la. A massa, ainda que fosse mais consciente do que é, não poderia discuti-la. Pois, para que uma coisa seja posta em questão, é necessário que se baseie numa norma razoável. Pode-se, por exemplo, discutir se a forma monogâmica do casamento é mais razoável do que a forma poligâmica, e fazer valer razões para uma e outra. Poder-se-ia, também, discutir um sistema de símbolos, pois o símbolo tem uma relação racional com o significado (ver p. 109); mas para a língua, sistema de signos arbitrário, falta essa base, e com ela desaparece todo terreno sólido de discussão; não existe motivo algum para preferir soeur a sister ou a irmã, ochs a boeuf ou a boi. (2012A, p. 113, itálicos no original).
\end{abstract}

E é partindo do princípio da arbitrariedade que Saussure introduz a discussão sobre os valores no sistema linguístico.

\begin{abstract}
Estas considerações fazem compreender melhor o que foi dito na p. 108 s. sobre o arbitrário do signo. Não só os dois domínios ligados pelo fato linguístico são confusos e amorfos, como a escolha que se decide por tal porção acústica para essa ideia é perfeitamente arbitrária. Se não fosse o caso, a noção de valor perderia algo de seu caráter, pois conteria um elemento imposto de fora. Mas, de fato, os valores continuam a ser inteiramente relativos, e eis por que o vínculo entre a ideia e o som é radicalmente arbitrário. (2012A, p. 160).
\end{abstract}

Como afirmado acima, a delimitação do plano disforme das ideias e do plano disforme dos sons é arbitrária. Sua execução cria significantes e significados que são associados pela língua para produzir signos. E tanto significante quanto significado são entidades essencialmente formais: "A Linguística trabalha, pois, no terreno limítrofe em que os elementos das duas ordens se combinam; essa combinação produz uma forma, não uma substância." 
(2012A, p. 160, itálicos no original). Como formas, significante e significado puderam ser definidos como instruções que permitem a formatação do plano disforme das ideias e do plano disforme dos sons. E se os elementos constitutivos do signo são essencialmente formas (pois não apresentam uma substância que seja relevante), como então determinar seu valor dentro do sistema? Saussure recorre à ideia de valor linguístico para solucionar essa questão.

Ser eminentemente uma forma significa afirmar que cada entidade concreta da língua (cada signo) não possui um valor em si, substancial. Por isso, o valor identificável em cada entidade concreta só pode ser derivado de sua posição no sistema e das relações que mantém com as demais entidades componentes desse sistema (posição e relações como formas do sistema). O conjunto de relações modela o valor de cada entidade: cada entidade tem seu valor delimitado pelo valor das demais entidades. Essa inter-delimitação valorativa faz com que no sistema da língua existam apenas relações de oposição. Opor-se é ser algo distinto. E se o valor decorre de relações de oposição, possuir valor é ser o que não são aqueles com que me relaciono. Cada entidade concreta da língua, portanto, por opor-se às demais entidades, adquire um valor que a torna distinta, simplesmente por ser o que as outras entidades não são. Na língua, o ser do signo é definido por relações de alteridade: sou o que não são os demais, que não são o que eu sou, já que nos delimitamos. Valer é opor-se, é distinguir-se no interior do sistema.

Unidade e fato de gramática não se confundiriam se os signos linguísticos fossem
constituídos por algo mais que diferenças. Mas sendo a língua o que é, de qualquer
lado que a abordemos não lhe encontraremos nada de simples; em toda parte e sempre,
esse mesmo equilíbrio de termos complexos que se condicionam reciprocamente. Dito
de outro modo, a língua é uma forma, e não uma substância (ver p. 160). Nunca nos
compenetraremos o bastante dessa verdade, pois todos os erros de nossa terminologia,
todas as maneiras incorretas de designar as coisas da língua provêm da suposição
involuntária de que haveria uma substância no fenômeno linguístico. (2012A, p.
169/170, itálicos no original).

Pois bem, e como são essas relações de oposição que definem o valor do signo linguístico no interior do sistema da língua? Segundo Saussure, são de duas espécies: de natureza sintagmática e de natureza associativa.

O conjunto de diferenças fônicas e conceituais que constitui a língua resulta, pois, de duas espécies de comparações; as aproximações são ora associativas, ora sintagmáticas; os agrupamentos de uma e de outra espécie são, em grande medida, estabelecidos pela língua; é esse conjunto de relações usuais que a constitui e que lhe preside o funcionamento. (2012A, p. 176). 
As relações sintagmáticas são consequência necessária do princípio da linearidade do significante do signo linguístico. Em resumo, esse princípio descreve a lógica da realização do sistema linguístico na fala que, por possuir uma extensão linear, impede que dois signos sejam pronunciados concomitantemente.

\begin{abstract}
O significante, sendo de natureza auditiva, desenvolve-se no tempo, unicamente, e tem as características que toma do tempo: a) representa uma extensão, e b) essa extensão é mensurável numa só dimensão: é uma linha. (2012A, p. 110, itálicos no original).

De um lado, no discurso, os termos estabelecem entre si, em virtude de seu encadeamento, relações baseadas no caráter linear da língua, que exclui a possibilidade de pronunciar dois elementos ao mesmo tempo (ver p. 110). Estes se alinham um após o outro na cadeia da fala. Tais combinações, que se apoiam na extensão, podem ser chamadas de sintagmas. (2012A, p. 171).
\end{abstract}

Por outro lado, para que um sintagma exista, é necessário que ao menos dois signos sejam alinhados. Com isso, na fala que produz o sintagma, os signos são pronunciados um após o outro; e o valor de cada signo componente do sintagma deriva de sua oposição ao signo que lhe antecede e ao signo que lhe sucede: "Colocado num sintagma, um termo só adquire seu valor porque se opõe ao que o precede ou ao que o segue, ou a ambos.” (2012A, p. 172).

As relações associativas, por sua vez, não são identificadas no discurso, mas no cérebro daquele que fala a língua: "Elas não têm por base a extensão; sua sede está no cérebro; elas fazem parte desse tesouro interior que constitui a língua de cada indivíduo. Chamá-lasemos relações associativas." (2012A, p. 172, itálicos no original). A memória, segundo Saussure, registra um acervo de signos que, não obstante oponentes, guardam algum tipo de identidade (semântica, morfológica, ortográfica etc.): "Por outro lado, fora do discurso, as palavras que oferecem algo de comum se associam na memória e assim se formam grupos dentro dos quais imperam relações muito diversas.” (2012A, p. 172). Ao contrário do que possa parecer, a memória, como suporte do sistema linguístico, não guarda apenas grupos de relações entre signos que apresentam algum tipo de identidade, mas também mantém sintagmas já estabilizados pelo uso, como frases feitas, que influenciam a própria formação do sintagma no ato idiossincrático da fala. 
Há, primeiramente, um grande número de expressões que pertencem à língua; são as frases feitas, nas quais o uso proíbe qualquer modificação, mesmo quando seja possível distinguir, pela reflexão, as partes significativas (...). (2012A, p. 173).

Cumpre reconhecer, porém, que no domínio do sintagma não há limite categórico entre o fato da língua, testemunho de uso coletivo, e o fato de fala, que depende da liberdade individual. Num grande número de casos, é difícil classificar uma combinação de unidades, porque ambos os fatores concorreram para produzi-la e em proporções impossíveis de determinar. (2012A, p. 174).

Desses dois tipos de relação (as duas relações existentes no sistema linguístico) resulta o valor do signo linguístico enquanto entidade. Antes de ser realizado no discurso, o signo é agrupado pela língua (relações associativas) a outros signos que com ele compartilhem qualquer semelhança. Esse agrupamento permite que as oposições entre signos minimamente semelhantes sejam ressaltadas. Imaginemos um agrupamento de advérbios de modo - sendo esta classificação gramatical o fator de semelhança; eles são agrupados nessa categoria justamente para destacar suas oposições: apesar de apresentarem alguma semelhança, cada advérbio é oposto aos demais advérbios e, por isso, existe nesse agrupamento. Ou seja, a semelhança só é possível porque existe oposição. Mas não é só; além de sobrelevar as oposições entre diferentes signos minimamente semelhantes, as relações associativas instrumentalizam as relações sintagmáticas. No exercício da fala, aquele que fala sempre considera, além das oposições sintagmáticas, as oposições associativas: se pensa em empregar um advérbio de modo que se mostre pertinente para ocupar aquela posição da cadeia sintagmática, escolhe aquele cujo valor associativo melhor se adéque também àquela posição.

\footnotetext{
Por conseguinte, não basta dizer, colocando-se num ponto de vista positivo, que se toma vamos! porque significa o que se quer exprimir. Na realidade, a ideia invoca não uma forma, mas todo um sistema latente, graças ao qual se obtêm as oposições necessárias à constituição do signo. Este não teria, por si só, nenhuma significação própria. O dia em que não houvesse mais vai! em face de vamos! cairiam certas oposições e o valor de vamos! estaria mudado ipso facto. (2012A, p. 179, itálicos no original).
}

Portanto, o valor de um signo só é completamente aferível quando consideradas as relações associativas, as que a língua mantém em memória, e as relações sintagmáticas que ocorrem na fala em que foi realizado. Em outros termos, dentro do sistema da língua, um signo só possui valor porque mantém relações associativas e sintagmáticas com os demais signos do 
sistema. O valor é o fator de ratificação da existência do signo como entidade concreta do sistema linguístico: valer é ser distinto, é existir no sistema linguístico.

Mas se o signo linguístico é algo que existe no sistema linguístico, isto é, na língua, qual seria seu modo de ser característico? Saussure deu algumas pistas de um como que caracteriza o ser do signo linguístico. Vejamos. Definiu o signo linguístico como a unidade, formada pela associação de um significante e um significando, resultante de uma segmentação simultaneamente realizada pela língua "sobre o plano indefinido das ideias confusas $(A)$ e sobre o plano não menos indeterminado dos sons (B)". Ou seja, é por meio dos signos que a língua consegue dar forma a dois planos anteriormente disformes. A língua forma signos para poder formar o plano das ideias e o plano dos sons, ainda que essas duas formações (do signo e dos planos formados) ocorram simultaneamente. Dar forma a dois planos disformes é criar signos, e criar signos é dar forma a dois planos disformes. São os signos que instrumentalizam essa formação.

O instrumentalizar é um modo de ser e a instrumentalidade é o modo de ser do signo linguístico (ser-instrumental). O signo linguístico, sendo, mostra-se em seu modo de ser como instrumento, como algo que pode ser usado para alguma finalidade. Especificamente, é o instrumento usado pela língua para dar forma ao plano das ideias confusas e ao plano dos sons. A língua cria-o para usá-lo, usa-o porque cria-o. E porque instrumentaliza a formação realizada pela língua, seu modo de ser-instrumental pode ser também descrito como ser-para-a-língua. O signo existe para ser usado para algo pela língua. 


\title{
Capítulo 2. Louis Hjelmslev.
}

\begin{abstract}
Na prática, uma língua é uma semiótica na qual todas as outras semióticas podem ser traduzidas, tanto todas as outras línguas quanto todas as estruturas semióticas concebíveis. Esta tradutibilidade resulta do fato de que as línguas, e elas apenas, são capazes de formar não importa qual sentido; é apenas uma língua que é possível "ocupar-se com o inexprimível até que ele seja exprimido". (...). Estamos inclinados a supor que a razão disso é a possibilidade ilimitada de formação de signos e as regras bastante livres que regem a formação de unidades de grande extensão (como as frases, por exemplo) em todas as línguas, o que, por outro lado, tem por efeito o fato de permitir formulações falsas, ilógicas, imprecisas, feias e imorais, bem como formulações verdadeiras, lógicas, precisas, belas e morais. As regras gramaticais de uma língua são independentes de toda escala de valores, quer seja lógica, estética ou ética e, de modo geral, a língua é desprovida de qualquer finalidade específica. (2013, p. 115/116).
\end{abstract}

\section{a) Preliminarmente}

Não tenho dúvida de que afirmar o quão difícil é a leitura da obra de Hjelmslev já adquiriu a qualidade de lugar comum. Talvez a dificuldade advenha de seu fascínio pelas formas, ou talvez de seu exacerbado respeito à epistemologia, ou ainda de sua incrível capacidade de definir e inter-definir todos os conceitos com que lida.

Um dos sentidos humanos, o que recebeu a denominação "visão", apresenta em Hjelmslev uma característica marcante: foco seletivo. Enquanto enxergava seu objeto de estudo a fim de estudá-lo, Hjelmslev separava formas e substâncias com uma eficácia praticamente automática. Bastava olhar para um texto para identificar uma linha da forma da expressão e uma linha da forma do conteúdo como funtivos da função semiótica que arbitrariamente projetava tais formas sobre uma substância não-linguística.

Entre funções e funtivos, tudo que Hjelmslev chegou a definir foi sempre analisado em sua forma. E forma é sinônimo de relação, ou dependência entre duas coisas. Assim, toda definição criada por Hjelmslev aponta a relação (função) que constitui o definido ou a relação em que o definido entra como constitutivo, sendo um dos funtivos dessa função. Como não há brechas no sistema de definições proposto por Hjelmslev (afinal, todas são estritamente formais), tentar extrair de suas palavras uma espécie de fenomenologia da língua e do signo linguístico foi extremamente complicado - e essa certamente foi a maior dificuldade encontrada. 
Veja, reproduzir a definição de língua proposta por Hjelmslev é extremante fácil, basta abrir a parte final dos Prolegômenos, encontrar o verbete "língua" e conectá-lo a outros verbetes que complementam sua definição. Eis a língua em sua estrutura, ou como Hjelmslev a enxerga estruturalmente. Mas como a língua pode ser interpretada fenomenologicamente? Quais são as características de seu modo de ser? Será possível identificar uma interpretação deste tipo em Hjelmslev? ${ }^{10}$ Foi o que tentei realizar.

\section{b) A língua}

Ao dedicar-se especificamente à análise da língua, Hjelmslev não se acanhou ao declarar a influência que Saussure exerceu sobre seu pensamento. Essa análise foi realizada no ensaio "Língua e fala"11, um dos capítulos da obra Ensaios Linguísticos, que foi publicado no ano de 1943, coincidindo com o ano da primeira publicação dos Prolegômenos a uma Teoria da Linguagem (2013). Não obstante a concomitância temporânea, a discussão que Hjelmslev desenvolve nesse ensaio sobre os conceitos saussurianos de língua e fala não foi repetida nos Prolegômenos. Porém, por considerá-la extremamente relevante, resolvi resumi-la.

Esse ensaio deixou transparecer dois sentimentos que certamente influenciaram Hjelmslev durante sua redação. Por um lado, é evidente a intenção de mencionar honrosamente seu precursor. Demonstra com nitidez como seu pensamento tem como origem os conceitos saussurianos (algo que se repete em outros ensaios e mesmo nos Prolegômenos). Por outro lado, contudo, por ter desenvolvido os conceitos saussurianos que lhe serviram de base, e descartado outros conceitos (como o de "fala" que será comentado adiante), Hjelmslev sentia a necessidade de distinguir, da forma mais transparente possível, o que remanesceu de Saussure do que é originariamente seu. Esse segundo sentimento fez com que Hjelmslev não escondesse suas discordâncias, que evidenciou. E é através do interessante dissenso elaborado no ensaio "Língua e fala" que Hjelmslev explica por que descartou a dicotomia saussuriana língua/fala para adotar a dicotomia esquema/uso. Este ensaio também esclarece o motivo que levou Hjelmslev a não adotar o conceito de fala nas definições de seus Prolegômenos e a origem da fragmentação do conceito de língua, que passou a ser oposto ao conceito de texto e a apresentar

\footnotetext{
${ }^{10}$ Sobretudo quando se considera que o próprio Hjelmslev afirma ter evitado qualquer consideração de caráter ontológico para definir a língua: "Está visto que a descrição de uma língua deve começar por afirmar as relações entre as unidades relevantes, e essas afirmações não podem envolver uma afirmação sobre a natureza inerente, a essência ou a substância das próprias unidades.” (1991, p. 43).

11 1991, p. 81/94.
} 
alguns sinônimos que exercem, no interior da glossemática, diferentes funções. Vejamos tudo isso como prolegômenos aos Prolegômenos.

Ainda sem o rigor formal que permeará todas suas definições futuras, Hjelmslev repetiu a fórmula saussuriana para definir a língua, ao lado da fala, como um dos elementos constitutivos de uma totalidade que a contém - totalidade que é a linguagem. A língua e a fala constituem a linguagem, que "é a totalidade constituída pela língua e pela fala".

O termo linguagem é aqui tomado no sentido técnico que usualmente lhe é atribuído na literatura científica de língua francesa e que foi precisado e codificado no Cours de linguistique générale, de F. de Saussure: a linguagem é a totalidade constituída pela língua e pela fala. Portanto, ao falar aqui de linguagem, falamos da linguagem humana em geral, e ao mesmo tempo de cada uma das línguas, consideradas em sua relação com a fala que serve para manifestá-la. (1991, p. 31, itálicos no original).

Essa tautologia, certamente notada por Hjelmslev, ligada à necessidade que sentia de evitar e suprimir ambiguidades, motivaram a redefinição que promoveu sobre esses três conceitos, que receberam contornos não delineados pelo mestre genebrino.

Sobre a língua, Hjelmslev constatou que Saussure a ela conferiu sentidos diversos: sentido de sistema, sentido de realização material e sentido de convenção social (conjunto de hábitos daqueles que falam). Para cada um desses sentidos Hjelmslev atribuiu a denominação, respectivamente, de esquema, norma e uso.

Por outro lado, essa ideia do esquema, conquanto claramente predominante na concepção saussuriana, não é o seu único fator constitutivo. A "imagem acústica” de que ele falou em muitas passagens do Cours não poderia ser senão a tradução física de um fato material; liga ela, pois, a língua a uma matéria dada e a assimila à norma. Diz, ademais, que a língua é o conjunto dos hábitos linguísticos; a língua, portanto, não seria nada mais do que um uso. (1991, p. 87/88, itálicos no original).

De fato, tendo em vista suas opções metodológicas, não conviria a Hjelmslev afirmar que a língua pode ser definida como algo além de um esquema; ou seja, definida também como uma realização material e como algo que é habitualmente manifestado por aqueles que a falam. Por esse motivo, afirmou que somente a definição de língua como esquema seria capaz de concretizar o famoso princípio saussuriano que diz que a língua é forma e não substância. "É 
ela, enfim, que constitui a máxima fundamental segundo a qual a língua é uma forma, não uma substância." (1991, p. 87).

A distinção entre forma e substância, que será amplamente explicada mais adiante, ilustra, em resumo, a distinção entre o que é constante e o que é variável. Tudo o que é constante remete à forma de um conceito, constitui o que lhe é essencial e mostra-se suficiente para definilo; tudo que é variável remete à substância, ao que é acessório para um conceito, acessório porque substituível, não sendo relevante para sua definição. E Hjelmslev percebeu que em qualquer língua o que sempre se apresenta como constante é seu esquema, sua estrutura interna, jamais sua realização material ou os hábitos usuais daqueles que a falam. "Em todo sistema semiológico, o esquema constitui a constante, isto é, o pressuposto, ao passo que, em relação ao esquema, a norma, o uso e o ato são as variáveis, ou seja, aqueles que pressupõem.” (1991, p. 90$)^{12}$.

O conceito de realização material reflete repetições de caráter material e eventual constatáveis na substância que promove a manifestação da língua. Como, no entanto, o esquema pode ser manifestado por substâncias diversas e cada uma dessas substâncias pode apresentar repetições materiais diversas, a realização material apresenta-se como variável relativamente ao esquema. Como variável, as alterações que afetam a realização material não são capazes de alterar a estrutura essencial da língua, que é o esquema constante. Já a noção de norma, tomada como sinônimo de realização material por Hjelmslev, não passa de uma ficção, pois apenas descreve recorrências materiais do uso, que podem variar indeterminadamente. Ou seja, o que é descrito como norma não faz jus a tal denominação.

\begin{abstract}
A norma, de outra parte, é uma ficção - a única ficção que se encontra entre as noções que nos interessam. $\mathrm{O}$ uso, compreendendo o ato, não o é. $\mathrm{O}$ esquema, também não. Essas noções representam realidades. A norma, pelo contrário, é apenas uma abstração tirada do uso por um artifício de método. Constitui, quando muito, um corolário conveniente para estabelecer os quadros da descrição do uso. Para falar estritamente, é supérflua; constitui algo assim como um acréscimo e uma complicação inútil. (1991, p. 92, itálicos no original).
\end{abstract}

Sobre o uso, Hjelmslev define-o como "substância que manifesta o esquema linguístico"13. Como afirmado no parágrafo anterior, uma mesma forma do esquema linguístico pode ser manifestada por diversas substâncias, por diversos usos. Ou seja, a não-fixidez da

\footnotetext{
${ }^{12}$ Observação: sistema semiológico é o gênero que contém a língua; a língua é uma espécie de sistema semiológico.

${ }^{13}$ Ver verbetes n. 66 e 92 do quadro de definições presente no final do Prolegômenos a uma Teoria da Linguagem.
} 
substância lhe impõe a qualidade de variável relativamente à língua e à constância de seu esquema. Hjelmslev ressalta que o conceito de uso se refere tanto às manifestações individuais (atos de manifestação) quanto ao conjunto social de manifestações de um mesmo esquema linguístico: "De fato, a execução do esquema seria necessariamente um uso: uso coletivo e uso individual." (1991, p. 92). A esfera social é a ilustração do conjunto de hábitos adotados pela sociedade no exercício do uso, na manifestação substancial do esquema; a esfera individual é o ato individualizado de manifestação do esquema. Porém, tanto na esfera individual quanto na esfera social o uso é variável, não sendo capaz de afetar a autonomia do esquema.

Sobre o esquema, Hjelmslev vale-se do conceito saussuriano de "valor" para explicá$10^{14}$. No esquema da língua, os elementos que o compõem possuem valor independentemente de qualquer realização material ou manifestação substancial. Seu valor dentro do esquema deriva das relações de alteridade que mantém com os demais elementos do sistema. Um elemento vale o que não valem os demais. Vale-se porque difere-se. Valer é ser diferente, e ser diferente é relacionar-se com o que é diferente - existir solidariamente ao lado do que é diferente. Esquema é uma forma pura.

É possível então concluir que a realização material e o uso são, ao contrário do esquema, elementos variáveis que não apresentam relação direta com o núcleo sistemático da língua; são elementos substituíveis que, quando substituídos, não têm o condão de promover qualquer variação essencial no esquema. Consequentemente, as variáveis, a norma e o uso, pressupõem a constante, o esquema (não há norma ou uso sem que exista um esquema que lhes dê fundamento), porém, o esquema não pressupõe a norma e o uso, pois pode existir sem que estes existam.

Para absterger esse emaranhado de sentidos (esquema, norma e uso) e vislumbrar a língua como uma forma pura, Hjelmslev afastou as características da realização material e do uso e salientou a característica sistemática para concretizar uma definição adequada. A definição da língua exclusivamente como esquema mostrou-se perfeitamente suficiente para explicá-la, bastante para permitir visualizá-la como forma depurada e também para atingi-la naquilo que lhe é essencial, abarcando assim tudo que se apresenta como constante sem, contudo, poluir-se com o que se apresenta como variável: "Caso se queira chegar a uma definição que toque o essencial do sentido atribuído na vida cotidiana e prática da palavra língua, deve-se evidentemente reter o sentido de esquema." (1991, p. 87, itálicos no original).

\footnotetext{
${ }^{14}$ Hjelmslev não define objetivamente o conceito de esquema, mas vale-se do conceito de valor para diferenciálo dos conceitos de norma e uso. Para identificar a definição de esquema, ver p. 84/86 e 89/90 (1991).
} 
Consolidada a definição de língua como esquema, como forma pura, Hjelmslev passa a analisar o conceito saussuriano de "fala". Para isso, Hjelmslev rememorou a oposição binominal execução/instituição: "Segundo a doutrina do Cours, a fala se distingue da língua por três qualidades: 1) é uma execução, e não uma instituição; (...).” (1991, p. 91, itálicos no original). Essa oposição foi proposta pelo mestre genebrino para distinguir a fala, que seria executiva, da língua, que seria institucional. Assim, a fala, como execução, seria a realização da língua, que é uma convenção instituída socialmente. Acontece que, para caracterizar a fala como realização da língua, Saussure a ela conferiu qualidades substanciais relacionadas aos sons e à fonação. Qualidades definidas por Hjelmslev como variáveis e que, por esse motivo, ensejaram uma aproximação entre os conceitos de fala e uso:

\begin{abstract}
De um ponto de vista semiológico, parece evidente que o Cours tem razão ao encerrar todo o mecanismo psicofísico nos quadros da fala e determinar a "fonologia" como uma disciplina que ressalta apenas a fala. É aqui que se encontra a fronteira essencial: aquela entre forma pura e a substância, entre o incorporal e o material. Isso nos leva a dizer que a teoria da instituição se reduz a uma teoria do esquema, e que a teoria da execução encerra toda a teoria da substância, tendo por objeto aquilo que aqui chamamos de norma, uso e ato. Norma, uso e ato estão, por outro lado, intimamente ligados e tendem naturalmente a não constituir senão o objeto verdadeiro: o uso, em relação ao qual a norma é a abstração, e ato uma concretização. É unicamente o uso que constitui o objeto da teoria da execução; a norma, na realidade, nada mais é que uma construção artificial, e o ato, por sua vez, é apenas um documento passageiro. (1991, p. 91/92, itálicos no original).
\end{abstract}

É notável como Hjelmslev principia o parágrafo comentando sobre o conceito de "fala" saussuriano e encerra-o com seu conceito de "uso". O início do emprego do termo "uso", ou o fim do emprego do termo "fala", coincide com o início das considerações sobre a "teoria da execução". Uma teoria é uma hipótese científica elaborada acerca de um objeto de estudo. E Hjelmslev não considera a fala, ou o conceito de fala, um objeto adequado a uma teoria da execução:

Através de uma análise prévia das noções, cremos haver separado o que existe de essencial e de verdadeiramente novo na língua saussuriana: é o que chamamos de esquema. Por outro lado, esse resultado nos conduziu a uma nova simplificação, que nos leva a propor a distinção entre esquema e uso como a única subdivisão essencial que se impõe à semiologia, devendo ela substituir a divisão entre língua e fala, a qual, se estivermos certos, não constitui senão uma primeira aproximação, historicamente importante, mas teoricamente imperfeita. (1991, p. 93, itálicos no original). 
O motivo do descarte do conceito de fala parece ser o fato de Saussure lhe atribuir a característica de ser "individual" como forma de opô-la ao caráter social que conferiu à convenção que define a língua. Ora, para Hjelmslev, como apontado acima, a manifestação da língua (o uso) não é apenas individual, mas também social. Portanto, o conceito saussuriano revelou-se insuficiente para denominar a definição de manifestação, mais adequadamente denominada pelo conceito de "uso", termo que prevaleceu nos Prolegômenos.

Apesar de rejeitar a oposição entre língua e fala e, diante disso, inutilizar o conceito de fala, Hjelmslev não repete tal atitude com relação ao conceito de língua, cuja definição enquanto esquema é preservada. Por esse motivo, uma teoria da instituição (aquilo que é estável e formal na língua) deverá ter como objeto o esquema. Essa é a origem da oposição esquema/uso que será empregada nos Prolegômenos.

Passando finalmente aos Prolegômenos, temos que "esquema", como sinônimo de "língua" ${ }^{15}$, adquire função dentro da glossemática em oposição ao conceito de "uso". O termo "esquema”, contudo, não é o único sinônimo de língua adotado por Hjelmslev em sua terminologia; há ainda os conceitos de: (a) paradigmática e (b) sistema.

\begin{abstract}
Ora, como já vimos (Cap. 2), processo e sistema são conceitos de uma grande generalidade, e que não poderiam ter seu uso restrito exclusivamente a objetos semióticos. Encontramos designações cômodas e tradicionais para um processo e um sistema semióticos nos termos sintagmática e paradigmática. Quando se trata da língua natural falada, que é a única a nos interessar no momento, podemos também utilizar termos mais simples: chamaremos aqui processo de texto, e o sistema de lingua. (2013, p. 43/44).
\end{abstract}

Cada um destes termos adquire diferente função no interior dos Prolegômenos. Para o termo "paradigmática", Hjelmslev reserva a oposição ao termo "sintagmática"; e para o termo “sistema”, oposição ao termo "processo". É sobre cada uma dessas oposições que me debruçarei a partir de agora, com a esperança de identificar a interpretação de caráter fenomenológico. Começarei pela oposição reservada especificamente para o termo "língua": língua e texto.

A oposição entre os conceitos de língua e de texto é empregada por Hjelmslev no início dos Prolegômenos para introduzir as bases epistemológicas de sua Teoria da Linguagem. Nesse princípio, tanto a língua quanto o texto assumem o papel de objeto. A Teoria da Linguagem

\footnotetext{
${ }^{15}$ Ver verbete n. 91 das definições dos Prolegômenos a uma Teoria da Linguagem.
} 
objetiva encontrar uma constância por trás de toda linguagem, uma estrutura que esteja despoluída de qualquer dado extralinguístico e que, por esse motivo, possa ser estudada e descrita como forma pura. E essa estrutura é a língua, a constância que permite que a linguagem seja projetada sobre quaisquer dados extralinguísticos sem que seu conteúdo fundamental seja alterado. É a estrutura linguística que sempre permitirá identificar uma língua como língua, independentemente das variáveis extralinguísticas que a ela estejam relacionadas, independentemente da linguagem que seja analisada. A língua é, portanto, o modelo exordial de estrutura constante por trás da linguagem, é o sistema que a Teoria da Linguagem busca identificar e descrever.

\begin{abstract}
Uma teoria que procura a estrutura específica da linguagem com a ajuda de um sistema de premissas exclusivamente formais deve necessariamente (...) procurar uma constância que não esteja enraizada numa "realidade" extralinguística; uma constância que faça com que toda língua seja linguagem, seja qual for a língua, e que uma determinada língua permaneça idêntica a si mesma através de suas manifestações mais diversas; uma constância que, uma vez encontrada e descrita, se deixe projetar sobre a "realidade" ambiente seja qual for a natureza desta (física, fisiológica, psicológica, lógica, ontológica) de modo que esta "realidade" se ordene ao redor do centro de referência que é a linguagem, não mais como um conglomerado, mas sim, como um todo organizado que tem a estrutura linguística como princípio dominante. (2013, p. 7, itálicos no original).
\end{abstract}

Já o texto, ao lado da língua, é objeto sobre o qual a teoria vai debruçar-se para conhecer e descrever. Hjelmslev diz que a Teoria da Linguagem deve interessar-se pelo texto e, além, ser capaz de descrever todo e qualquer texto, existente ou por existir, redigido não importa em qual língua.

Todavia, não basta que a teoria da linguagem permita descrever e elaborar todos os textos possíveis de uma dada língua; é necessário ainda que, sobre a base dos conhecimentos que a teoria da linguagem em geral contém, essa teoria possa fazer a mesma coisa em relação a todos os textos de qualquer outra língua. (2013, p. 20).

Assim, relativamente à Teoria da Linguagem, os conceitos de língua e texto aproximam-se pela qualidade de objeto que titulam, pois ambos são os objetos estudados e explicados pela teoria, mas opõem-se porque a língua é um objeto não-evidente, que não se apresenta concretamente ao conhecimento, enquanto o texto, por sua vez, mostra-se sempre 
materialmente, materializado em alguma substância manifestada. Como então estudar a língua? Como acessar suas estruturas? Hjelmslev responde que é através do texto que o linguista terá acesso às estruturas da língua. A língua, que permite a produção de qualquer texto, ao fazê-lo, deixa transparecer suas estruturas no interior dos textos cuja produção permitiu. Ou seja, o texto, apesar de ter existência própria, repleta de dados extralinguísticos, é sempre estruturado por uma língua.

É a partir dessa nova oposição entre os conceitos de língua e de texto (oposição que excede a simples aproximação como objetos da Teoria da Linguagem), como acessível e acesso, ou como estruturante e estruturado, que Hjelmslev introduz um novo binômio, composto pelos conceitos sistema/processo. O primeiro como sinônimo de língua e o segundo como sinônimo de texto.

\begin{abstract}
Ora, graças a nossos instrumentos teóricos, essa simples seleção de textos permite constituir um fundo de conhecimentos que por sua vez poderá ser aplicado a outros textos. Estes conhecimentos dizem respeito, naturalmente, aos processos ou textos de que foram extraídos; mas não reside nesse ponto seu interesse único e essencial: tais conhecimentos dizem respeito também ao sistema ou língua a partir da qual se elabora a estrutura de todos os textos de uma mesma suposta natureza, e que nos permite construir novos textos. Graças aos conhecimentos linguísticos assim obtidos, podemos elaborar, para uma mesma língua, todos os textos concebíveis ou teoricamente possíveis. (2013, p. 20, itálicos no original).
\end{abstract}

A língua é o sistema por trás de qualquer processo, de qualquer texto; e as estruturas da língua são identificáveis nos textos escritos nessa língua, onde aparecem como constantes entre variantes inumeráveis. Por isso a imprescindibilidade do estudo do processo por parte da Teoria da Linguagem, já que o processo, como processamento de uma língua, é a única forma de acessá-la enquanto sistema: "O objetivo da teoria da linguagem é verificar a tese da existência de um sistema subjacente ao processo, e a tese de uma constância que subentende as flutuações, e aplicar esse sistema a um objeto que parece prestar-se a isso de modo particular." (2013, p. 9).

A oposição existente entre os conceitos de sistema e de processo é definida como uma modalidade de determinação. Determinação é a função existente entre dois funtivos, um constante e outro variável ${ }^{16}$. O funtivo constante é o sistema e o variável é o processo. A existência do constante é indispensável para que o variável possa existir: não há variável sem

${ }^{16}$ Ver verbete n. 15 das definições dos Prolegômenos. 
que preexista uma constante; porém, uma constante pode existir sem que ainda exista qualquer variável com que mantenha relação, isto é, a existência da constante nunca depende da existência da variável a que está relacionada.

Por constante entendemos um funtivo cuja presença é uma condição necessária para a presença do funtivo com o qual tem função. Por variável, pelo contrário, entenderemos um funtivo cuja presença não é uma condição necessária para a presença do funtivo com o qual tem função. (2013, p. 40, itálicos no original).

Consequentemente, não há processo sem sistema, mas é possível haver sistema sem que haja processo. Um sistema não é necessariamente processado, mas para que ocorra processamento é indispensável que exista um sistema para ser processado. Resumindo o que foi dito até aqui:

\begin{abstract}
Um exame aprofundado dessa função mostra facilmente que é uma determinação cujo sistema é a constante: o processo determina o sistema. Não é essencial que, visto do exterior, o processo seja mais imediatamente perceptível à observação, enquanto que o sistema deve ser antes "relacionado" com o processo "descoberto" atrás dele mediante um procedimento; é apenas por isso que o único modo de conhecê-lo é o modo indireto, a menos que ele se apresente de imediato a partir de um procedimento preliminar. Esta situação poderia levar a pensar que o processo pode existir sem o sistema, e não o contrário. Mas o importante é que a existência de um sistema seja uma condição necessária para a existência de um processo. O processo só existe em virtude do sistema subjacente que o governa e que determina sua formação possível. Não seria possível imaginar um processo sem um sistema por trás dele porque neste caso tal processo seria inexplicável, no sentido absoluto da palavra. Um sistema, pelo contrário, não é inconcebível sem um processo. A existência de um sistema não pressupõe a existência de um processo. O sistema não existe em virtude de um processo. (2013, p. 44, itálicos no original).
\end{abstract}

Sendo o conceito de sistema um dos sinônimos do conceito de língua e o conceito de processo um dos sinônimos do conceito de texto, é possível afirmar que: a língua é pressuposta pelo texto, mas não o pressupõe, logo, pode existir sem que tenha dado origem a nenhum texto; por outro lado, o texto pressupõe a língua, portanto, não pode existir sem que preexista uma língua que lhe confira uma estrutura.

Se os conceitos de língua e de texto foram aproximados por Hjelmslev como os dois objetos constitutivos da Teoria da Linguagem, também cuidou de aproximar os conceitos de sistema e de processo ao defini-los como hierarquias: "Denominar-se-á de hierarquia uma 
classe de classes, e sabemos que teremos de distinguir entre duas espécies de hierarquias: os processos e os sistemas." (2013, p. 34, itálicos no original). Hierarquia é uma classe de classes, e classe é objeto submetido a análise por uma teoria. A classe pode ser dividida em componentes, que são objetos homogêneos que se definem exclusivamente pelas funções que mantêm entre si e com a totalidade da classe. Assim, a hierarquia é um objeto analisável por uma teoria cujos componentes são classes ${ }^{17}$.

O processo é uma hierarquia relacional, e os componentes de suas classes mantêm entre si uma função descrita pela expressão "e...e": "É sobre esta distinção que se baseia a distinção entre processo e sistema: no processo, no texto, encontra-se um e...e, uma conjunção, ou uma coexistência entre os funtivos que dela participam.” (2013, p. 41). As classes que compõem o processo são denominadas de cadeias e seus respectivos componentes são denominados de partes: "Num processo linguístico, as classes serão denominadas cadeias e os componentes partes." (2013, p. 34, itálicos no original). As partes em uma cadeia são posicionadas em sequência, uma após a outra, linear e sucessivamente. No interior da cadeia, as partes conjugam-se para constituí-la. Para tanto, cada parte apresenta-se em função com a que a precede e com a que lhe sucede na cadeia (“e...e"). E também a soma das partes forma uma função com a cadeia, isto é, entre a cadeia e suas partes existe uma função.

O sistema é classificado como hierarquia correlacional ${ }^{18}$. As classes que o compõem são denominadas de paradigmas e seus componentes são denominados de membros: "Num sistema linguístico, as classes serão denominadas paradigmas e os componentes membros." (2013, p. 34, itálicos no original). Os membros mantêm entre si uma função de caráter alternativo, que é ilustrada pela expressão "ou...ou": "No sistema, pelo contrário, existe um ou...ou, uma disjunção ou alternância entre os funtivos que dele participam.” (2013, p. 41/42). A alternatividade representa a possibilidade de alternância entre os membros de um paradigma. A alternância reflete uma correlação de semelhança e dessemelhança (a semelhança faz com que os membros estejam unidos em um mesmo paradigma; a dessemelhança faz com que sejam distintos, opostos) que cria alternativas de processamento para o processo. Cada membro processado foi alternativamente escolhido no interior de um paradigma da hierarquia correlacional: a semelhança permitiria que outro membro do mesmo paradigma fosse colocado

\footnotetext{
${ }^{17}$ Ver verbetes n. 1, 2, 3 e 4 do quadro de definições do Prolegômenos.

18 "Por correlação, entenderemos, portanto, a função ou...ou, e por relação a função e...e. Denominaremos os funtivos que contraem essas funções, respectivamente, de correlatos e relatos. A partir desta colocação, podemos definir um sistema como uma hierarquia correlacional e um processo como uma hierarquia relacional." (2013, p. 43, itálicos no original).
} 
na mesma posição da cadeia processual, mas a dessemelhança produziria uma diferença de sentido ${ }^{19}$.

Em resumo, o sistema é uma hierarquia de paradigmas e o processo uma hierarquia de cadeias. O primeiro é qualificado pela função ou...ou existente entre os membros dos paradigmas e o segundo pela função e...e constatável entre as partes das cadeias. Essa oposição motivou uma nova simplificação por parte de Hjelmslev, que denominou o sistema de paradigmática e o processo de sintagmática, novos sinônimos, destarte, dos conceitos de língua e de texto.

\begin{abstract}
Ora, como já vimos (Cap. 2), processo e sistema são conceitos de uma grande generalidade, e que não poderiam ter seu uso restrito exclusivamente a objetos semióticos. Encontramos designações cômodas e tradicionais para um processo e um sistema semióticos nos termos sintagmática e paradigmática. Quando se trata da língua natural falada, que é a única a nos interessar no momento, podemos também utilizar termos mais simples: chamaremos aqui processo de texto, e o sistema de lingua. (2013, p. 43/44, itálicos no original).
\end{abstract}

E a definição de língua como hierarquia correlacional, ou paradigmática, nos faz retornar ao conceito de esquema linguístico, cujo par opositivo é formado pelo conceito de uso (linguístico). Vejamos o parágrafo, agora dos Prolegômenos, em que Hjelmslev promove essa relação sinonímica entre os conceitos de hierarquia linguística e de esquema linguístico:

Chamaremos a hierarquia linguística de esquema linguístico, e as resultantes da hierarquia extralinguística de uso linguístico quando estão subordinadas ao esquema linguístico. Diremos, ainda, que o uso linguístico manifesta o esquema linguístico, e chamaremos de manifestação a função contraída pelo esquema e pelo uso. (2013, p. 83).

Relembrando a definição hjelmsleviana do conceito de uso linguístico, trata-se da substância que manifesta o esquema linguístico ${ }^{20}$. Na passagem acima citada, Hjelmslev substitui o termo substância pela expressão "hierarquia extralinguística" por um motivo: nos parágrafos anteriores ${ }^{21}$ tratou de demonstrar como a substância linguística - tudo que é

\footnotetext{
${ }^{19}$ Ver exemplos da p. 42 dos Prolegômenos.

${ }^{20}$ Ver nota de rodapé n. 14 desta dissertação.

${ }^{21}$ Ver capítulo n. 15 dos Prolegômenos a uma Teoria da Linguagem.
} 
extralinguístico ou externo ao esquema linguístico, mas que é formado pelo esquema linguístico - pode ser tomada como forma por outras ciências, que não a linguística. Neste caso, em que a substância linguística assume o papel de forma em outra ciência, para esta outra ciência, a substância passará a constituir uma hierarquia, mas, evidentemente, extralinguística.

Aquilo que, de um ponto de vista, é "substância" torna-se "forma" de outro ponto de vista; isto está relacionado com o fato de que os funtivos denotam apenas terminais ou pontos de intersecção das funções, e que apenas a malha funcional de dependências é acessível ao conhecimento e possui existência científica, enquanto que a "substância", no sentido ontológico, continua a ser um conceito metafísico.

A análise não linguística do sentido deve portanto levar, por dedução (no sentido que atribuímos a esse termo) ao reconhecimento de uma hierarquia extralinguística que contrai uma função com a hierarquia linguística obtida pela dedução linguística. (2013, p. 83).

Assim sendo, a hierarquia extralinguística variável (substância manifestante - uso) apresenta-se em função com a hierarquia linguística constante (esquema linguístico manifestado).

Mas o que significa dizer que o uso linguístico manifesta o esquema linguístico? O que é a manifestação? Vejamos. A manifestação é uma função, existente no processo, entre as constantes que são o esquema linguístico (formas) e as variáveis que são o uso linguístico (substância). Sendo uma função entre constantes e variáveis, é denominada de determinação, porém, ocorrendo no processo, é denominada de seleção. A manifestação é uma seleção entre formas linguísticas constantes e substâncias extralinguísticas variáveis ${ }^{22}$. Passando a olhar os funtivos da manifestação, as formas constantes e as substâncias variáveis, o esquema linguístico e o uso linguístico, é possível reafirmar que o esquema é o pressuposto de existência do uso, ou que não há uso sem que haja um esquema. Por outro lado, é também possível reafirmar que o esquema, constante, é manifestável por qualquer substância, variável.

Nesse cálculo geral, não se trata de se um tipo estrutural particular é manifestado, mas
apenas se é manifestável e, bem entendido, manifestável em qualquer substância.
Portanto, a substância não condiciona necessariamente a forma linguística, enquanto
que a forma linguística condiciona obrigatoriamente a substância. Em outras palavras,
a manifestação é uma seleção na qual a forma linguística é a constante e a substância,
a variável. Do ponto de vista formal, definimos a manifestação como uma seleção
entre hierarquias e derivadas de hierarquias diferentes. Concordando com Saussure,
pode-se chamar de forma a constante (a manifestada) de uma manifestação. Se a

${ }^{22}$ Ver verbete n. 50 e remissões do quadro de definições dos Prolegômenos. 
forma é uma língua, nós a chamamos de esquema linguístico. Sempre concordando com Saussure, pode-se chamar de substância a variável (a manifestante) de uma manifestação; chamaremos de uso linguístico uma substância que manifesta um esquema linguístico. (2013, p. 113, itálicos no original).

Pois bem, com todos esses conceitos esclarecidos, é possível apresentar e comentar finalmente a definição formal que Hjelmslev atribui ao conceito de língua: "Uma língua pode ser definida como uma paradigmática cujos paradigmas se manifestam por todos os sentidos (...).” (2013, p. 115). Uma paradigmática (em oposição a sintagmática) é sinônimo de hierarquia de paradigmas (em oposição a hierarquia de cadeias), que é sinônimo de sistema (em oposição a processo), que é sinônimo de língua (em oposição a texto), que é sinônimo de esquema linguístico (em oposição a uso linguístico). A língua é tudo isso, o conjunto de todos esses conceitos que, juntos, consolidam-na como uma forma pura, mas que é manifestável por substâncias extralinguísticas, por quaisquer substâncias extralinguísticas ${ }^{23}$. E são essas duas características que permitem a Hjelmslev, por um lado, incluí-la no conceito de "semiótica" e, por outro lado, distingui-la das demais semióticas englobáveis por esse conceito. A inclusão é permitida por sua natureza puramente formal; e a distinção deriva de sua capacidade de conformar qualquer substância.

Uma semiótica é qualquer hierarquia de classes (cujos componentes definem-se por serem mutuamente constantes) que seja definível como um esquema semiótico por ser funtivo de uma função (manifestação) com um uso semiótico ${ }^{24}$. Logo, o conceito de semiótica abrange o conceito de língua que é, contudo, uma semiótica um tanto especial, pois:

Na prática, uma língua é uma semiótica na qual todas as outras semióticas podem ser traduzidas, tanto todas as outras línguas quanto todas as outras semióticas concebíveis. Esta tradutibilidade resulta do fato de que as línguas, e elas apenas, são capazes de formar não importa qual sentido; é apenas uma língua que é possível ocupar-se com o "inexprimível até que ele seja exprimido". (2013, p. 115).

E foi nesse ponto que pude identificar a faísca de algo que Hjelmslev tanto se esforçou para evitar, a faísca de uma interpretação fenomenológica. Porém, sendo ainda uma faísca, tive

\footnotetext{
${ }^{23}$ No breve excerto citado, em que Hjelmslev apresenta sua definição formal do conceito de língua, emprega o termo "sentido", que é sinônimo de substância extralinguística (conjunto de variáveis). Ver verbetes n. 50, 52 e 69 do quadro de definições do Prolegômenos. A relação entre "sentido" e "substância" será mais debatida abaixo.

${ }^{24}$ Ver verbetes n. 53, 58 e 66.
} 
que assoprá-la para que se transformasse verdadeiramente em chama. Vejamos. A língua é uma semiótica especial porque é a única dentre todas as semióticas que é capaz de "formar não importa qual sentido". O "sentido" foi definido por Hjelmslev como "uma classe de variáveis que manifestam mais de uma cadeia em mais de uma sintagmática, e/ou mais de um paradigma em mais de uma paradigmática.” (2013, p. 115 e verbete n. 69 do quadro de definições). Pensando também no conceito de "substância": o sentido é a substância (variável e organizável por uma hierarquia extralinguística) que, na manifestação, encontra-se em função com as hierarquias linguísticas (paradigmática e sintagmática) constantes. Uma das passagens dos Prolegômenos que expressamente denomina a substância extralinguística como sentido é a seguinte:

\begin{abstract}
A teoria da linguagem tal como está estabelecida se sustenta ou cai com aquilo que denominamos de princípio de empirismo (cf. Cap. 3). Este nos leva (...) a aceitar como uma necessidade lógica a distinção saussuriana entre forma e "substância" (sentido), da qual resulta que a "substância" não pode em si mesma definir uma língua. Deve ser possível imaginar substâncias radicalmente diferentes do ponto de vista da hierarquia da substância que estejam ligadas a uma e mesma forma linguística; a relação arbitrária entre a forma linguística e o sentido faz disto uma necessidade lógica. (2013, p. 110, itálicos no original).
\end{abstract}

O sentido é, portanto, a substância variável que manifesta as formas constantes da língua. Há de se destacar, contudo, que o sentido só é capaz de manifestar as formas linguísticas porque destas formas recebeu uma formação. Ou seja, o sentido não preexiste à forma linguística, mas passa a existir linguisticamente somente quando é formado pela forma linguística. A língua pode formar qualquer substância e, com isso, poderia ter formado qualquer outra substância em lugar da substância que já formou. Por esse motivo, Hjelmslev afirma que a formação (a escolha da substância a ser formada e a escolha da forma que será imposta à substância), ou a relação existente entre forma linguística e sentido, é simplesmente arbitrária.

$\mathrm{E}$ a formação que a língua promove de qualquer modo sobre qualquer sentido marca não apenas a passagem do originariamente informe para o arbitrariamente formado, mas também, como aponta Hjelmslev, a passagem do incognoscível para o cognoscível.

Nas línguas, semelhanças e diferenças pertencem àquilo que, com Saussure, denominamos de forma, e não à substância que é formada. A priori, talvez se poderia supor que o sentido que se organiza pertence àquilo que é comum a todas as línguas $\mathrm{e}$, portanto, às suas semelhanças; mas isto é ilusão, pois ele assume sua forma de 
maneira específica em cada língua; não existe formação universal, mas apenas um princípio universal de formação. O sentido, em si mesmo, é informe, isto é, não está submetido, em si mesmo, a nenhuma formação, mas é suscetível de uma formação qualquer. Se há limites aqui, eles estão na formação e não no sentido. É por isso que o sentido é, em si mesmo, inacessível ao conhecimento, uma vez que a condição de todo conhecimento é uma análise, seja qual for sua natureza. Portanto, o sentido só pode ser conhecido através de uma formação, sem a qual ele não tem existência científica. (2013, p. 79).

Hjelmslev afirma que "o sentido é, em si mesmo, inacessível ao conhecimento", pois, “em si mesmo, é informe, não está submetido, em si mesmo, a nenhuma formação, mas é suscetível a uma formação qualquer". Em outros termos, o sentido, em si mesmo, não pode ser conhecido, pois, em si mesmo, não possui qualquer forma. Essa afirmação revela uma hipótese epistemológica assumida por Hjelmslev: apenas as formas podem ser apreendidas e conhecidas. E é possível imaginar o motivo que fundamenta essa hipótese. Se pensarmos numa substância (sentido) não-formada, numa substância que não possui forma alguma, nada se distingue, nada se diferencia, nada é de algum modo, pois tudo é do mesmo modo. Ou seja, se nada se distingue, nada pode ser conhecido, pois ao se observar o tudo não formado, não obstante tudo se observar, nada se observa dentro desse tudo, pois nada é observável. E se nada pode ser observado, nada pode ser conhecido. Mas talvez Hjelmslev de fato não tenha pensado nesse paradoxo do tudo versus o nada; talvez tenha pensado em algo mais simples, ou mesmo mais complexo. Fato é que, como diz, para que algo possa ser conhecido deve ser analisado, "uma vez que a condição de todo conhecimento é uma análise”. E uma análise é algo que se faz a partir de fora do objeto analisado, com a imposição de formas sobre o objeto que, em si mesmo, é informe. Pois são as formas que criam no objeto de análise uma estrutura de dependências internas, um sistema formado por funções entre elementos que existem em oposição recíproca. São tais formas que, inseridas no sentido, serão então analisadas e conhecidas; são tais formas que conferem alguma existência científica ao sentido.

Por conseguinte, diante disso tudo, dizer que a língua é uma semiótica especial porque é capaz de "formar não importa qual sentido" é o mesmo que dizer ao menos duas outras coisas: (a) que a língua se distingue por ser capaz de formar não importa qual "substância" (como sinônimo de "sentido"); e (b) que a língua se distingue por não sofrer limitações na formação do sentido - o que lhe abre a possibilidade de formar qualquer sentido, não importando qual. É essa, acredito, a origem da definição que Hjelmslev confere à língua (como citado acima, define-a como uma "paradigmática cujos paradigmas se manifestam por todos os sentidos"). A língua pode se manifestar por todos os sentidos, pois pode formar todos os sentidos. E essa 
possibilidade irrestrita de formação de sentidos acarreta uma consequência que não passou despercebida para Hjelmslev: a língua, podendo conferir forma a qualquer sentido, pode permitir o conhecimento de qualquer sentido. O que já foi por ela formado constitui o já cognoscível; e o que ainda não foi por ela formado representa o potencialmente cognoscível.

A língua é o acesso para qualquer conhecimento - é essa a interpretação fenomenológica da língua que encontrei em Hjelmslev. Seu modo de ser mostra-se em si mesmo como ser-o-cognoscível. Ou, de outro modo, a língua, sendo, mostra-se em seu modo de ser como o cognoscível. Ser-o-cognoscível é ser tudo que pode ser conhecido e tudo que se pode vir a conhecer. Com isso, para aqueles que falam a língua, ela é tudo que podem conhecer.

E mostra-se em seu modo de ser como o cognoscível não apenas por ter o poder de formar todo e qualquer sentido, mas também por ser capaz de traduzir em formas próprias o sentido já formado por outras semióticas. Ou seja, a língua tanto forma originariamente quanto reforma o já formado. Sobre isso, convém lembrar uma citação feita acima, que também permitirá introduzir o tema do item seguinte:

Na prática, uma língua é uma semiótica na qual todas as outras semióticas podem ser traduzidas, tanto todas as outras línguas quanto todas as outras semióticas concebíveis. Esta tradutibilidade resulta do fato de que as línguas, e elas apenas, são capazes de formar não importa qual sentido; é apenas uma língua que é possível ocupar-se com o "inexprimível até que ele seja exprimido". (2013, p. 115).

Para essa capacidade ilimitada de formação e reformação do sentido, Hjelmslev confere a seguinte explicação:

Estamos inclinados a supor que a razão disso é a possibilidade ilimitada de formação de signos e as regras bastante livres que regem a formação de unidades de grande extensão (como as frases, por exemplo) em todas as línguas, o que, por outro lado, tem por efeito o fato de permitir formulações falsas, ilógicas, imprecisas, feias e imorais, bem como formulações verdadeiras, lógicas, precisas, belas e morais. As regras gramaticais de uma língua são independentes de toda escala de valores, quer seja lógica, estética ou ética e, de modo geral, a língua é desprovida de qualquer finalidade específica. (2013, p. 115/116).

O que justifica, segundo Hjelmslev, a possibilidade irrestrita de formação e reformação do sentido que a língua possui? Algo também irrestrito, ilimitado, “a possibilidade ilimitada de 
formação de signos" ao lado das "regras bastante livres que regem a formação de unidades de grande extensão". Isto é, a língua, para formar o sentido, vale-se de signos; e, se pode formar qualquer sentido, é porque pode formar qualquer signo. E, além de poder formar qualquer signo, pode quase livremente alinhá-los para formar unidades de grande extensão. Destarte, Hjelmslev atribui ao signo linguístico a qualidade de ponto de encontro entre a forma e o sentido. Formar signos é formar sentido, é atribuir uma forma linguística a uma substância extralinguística. Assim, é através dos signos que a língua efetivamente delineia as substâncias segundo uma forma linguística. E os signos constituem o tema que será tratado no item abaixo.

Então, prossigamos.

\section{c) E o signo linguístico}

No final do item anterior foi dito que o signo linguístico é o responsável por promover o encontro entre a forma linguística e a substância extralinguística (o sentido), viabilizando que aquela seja manifestada por esta. Foi salientado, portanto, seu papel extremamente relevante no interior da língua, enquanto deixou-se no ar sua definição e o modo como opera o relacionamento entre forma e substância. Pois bem, o que é então o signo linguístico? E como ocorre a função entre forma e substância? Para chegar a tais respostas, Hjelmslev começa pela análise do conceito de signo proposto pela teoria linguística tradicional: o signo é sempre signo de alguma outra coisa.

\footnotetext{
Provisoriamente, devemos nos ater à definição tradicional, realista e imprecisa. Ela nos diz que um "signo" (ou, como diremos a fim de antecipar uma distinção terminológica que será introduzida mais tarde (Cap. 13), a expressão de um signo) é, de início e acima de tudo, signo de alguma outra coisa, particularidade que nos interessa desde logo pois parece indicar que um "signo" se define por uma função. Um "signo" funciona, designa, significa. Opondo-se a um não-signo, um "signo" é portador de uma significação. (2013, p. 49, itálicos no original).
}

Ser signo de outra coisa é significar outra coisa, é significar uma significação. Signo seria aquilo que possui uma significação e, com isso, significa algo além de si. O signo seria, portanto, a expressão de algo que lhe é externo, porém intimamente relacionado. Essa é a definição que Hjelmslev atribui à teoria tradicional e peremptoriamente julga como insustentável. Paralelamente, é também peremptório ao dizer alinhar-se à teoria moderna, de bases saussurianas: "No entanto, queremos demonstrar agora que, do ponto de vista linguístico, 
ela é insustentável; aliás, sob este aspecto estamos de acordo com as teorias linguísticas modernas." (2013, p. 53). De forma ligeira, diferencia as duas teorias da seguinte maneira:

\begin{abstract}
Segundo a teoria tradicional, o signo é a expressão de um conteúdo exterior ao próprio signo; pelo contrário, a teoria moderna (formulada em particular por F. de Saussure e, a seguir, por Leo Weisberger) concebe o signo como um todo formado por uma expressão e um conteúdo. (2013, p. 53, itálicos no original).
\end{abstract}

Por conseguinte, o que divide as teorias tradicional e moderna é a internalidade ou externalidade do conteúdo que é expresso pela expressão do signo. São as diferentes respostas que propõem à questão: o signo significa algo que lhe é externo ou algo que lhe é interno? Hjelmslev adianta sua posição (o signo é uma totalidade formada por expressão e conteúdo), mas inicia com cautela sua argumentação. Alerta para a dificuldade de delimitação da extensão do signo linguístico, o que até então havia frustrado suas tentativas de defini- $10^{25}$ (e, de fato, em meio às várias definições expostas ao final dos Prolegômenos, não se encontra qualquer definição de signo). Não obstante, para tentar de alguma forma defini-lo, resolve focar sua atenção sobre as duas grandezas igualmente presentes nas teorias tradicional e moderna: expressão e conteúdo. Independentemente da internalidade ou externalidade da relação entre expressão e conteúdo, é certo que há relação; logo, expressão e conteúdo são funtivos de uma função, a qual foi denominada por Hjelmslev de "função semiótica". A análise da função semiótica permitirá identificar se ela é interna ou externa ao signo linguístico; e é para demonstrar sua internalidade que Hjelmslev dedicará sua fundamentação.

É o critério de adequação que deve decidir sobre a escolha entre as duas concepções. Para tanto, deixaremos, por ora, de falar em signos, pois, não sabendo o que são, procuramos defini-los, a fim de falar daquilo cuja existência constatamos, isto é, a função semiótica, situada entre duas grandezas: expressão e conteúdo. É partindo dessa consideração fundamental que poderemos decidir se é adequado considerar a função semiótica como uma função externa ou interna da grandeza que chamamos de signo. (2013, p. 53, itálicos no original).

Vê-se que a função semiótica recebe uma definição estritamente formal: é a função existente entre a expressão e o conteúdo de qualquer signo linguístico. Se invertermos o

\footnotetext{
${ }^{25}$ Ver páginas 49/52 dos Prolegômenos.
} 
raciocínio: a expressão e o conteúdo são formalmente definidos como os funtivos da função semiótica. "Adotamos os termos expressão e conteúdo para designar os funtivos que contraem a função em questão, a função semiótica; esta é uma concepção puramente operacional e formal e, nesta ordem de ideias, nenhum outro significado é atribuído aos termos expressão e conteúdo." (2013, p. 53/54, itálicos no original). Porque definidos formalmente, a expressão e o conteúdo são suficientemente explicados pela função semiótica que mantêm entre si e pela função que mantêm com a função semiótica.

O signo, independentemente de sua extensão, mostra-se então, segundo Hjelmslev, como “(...) a unidade constituída pela forma do conteúdo e pela forma da expressão e estabelecida pela solidariedade que denominamos de função semiótica.” (2013, p. 62).

A expressão e o conteúdo, como elementos que se unem funcionalmente para constituir signo linguístico, receberam de Hjelmslev a denominação de planos. Consequentemente, diz-se que um signo é a grandeza composta por um plano da expressão e um plano do conteúdo.

É curioso notar como a exposição da função semiótica existente entre os dois planos que compõem o signo evidencia ainda mais a complexidade do papel que este exerce no interior da língua. O signo não apenas é encarregado de conduzir o encontro entre a forma linguística e a substância extralinguística, mas também é o responsável por unir expressão e conteúdo. E como se dá a relação entre a forma linguística e a substância extralinguística e o signo? Hjelmslev identificou formas e substâncias tanto em seu plano da expressão quanto em seu plano do conteúdo. A expressão possui uma forma e uma substância e, igualmente, o conteúdo possui uma forma e uma substância. E se expressão e conteúdo foram denominados de planos; a forma, da expressão e do conteúdo, e a substância, da expressão e do conteúdo, receberam a designação de estratos.

Por conseguinte, é interessante dispormos de um nome comum para designá-las. Aliás, é um fato digno de atenção que na terminologia consagrada desde o Cours, de Saussure, dispomos da palavra planos para designar o conteúdo (o significado) e a expressão (o significante), mas não possuímos um termo comum que sirva para designar as quatro grandezas ora consideradas. Propomos chamá-las de estratos. (1991, p. 50, itálicos no original).

Os estratos do signo linguístico são arbitrariamente relacionados pela função semiótica. Isto é, não há motivação na escolha de uma substância para manifestar uma forma e, 
o que parece ainda mais evidente, não há substância que necessariamente deva manifestar uma forma.

\begin{abstract}
Graças a seu caráter arbitrário, essas denominações não comportam nada que implique na manifestação, e graças a sua adequação, são escolhidas de modo tal que se possa, do modo mais simples possível, ordenar as informações sobre a manifestação. Em virtude do relacionamento arbitrário entre forma e substância, uma única grandeza da forma linguística poderá ser manifestada por formas de substância inteiramente diferentes de uma língua para outra. A projeção da hierarquia da forma sobre a da substância pode ser essencialmente diferente segundo as línguas. (2013, p. 104).
\end{abstract}

A arbitrariedade que qualifica a função semiótica cria uma supremacia da forma sobre a substância, do que é constante sobre o que é variável. A função semiótica cria uma forma da expressão e recorta, dentre várias substâncias, uma para manifestá-la. É somente após esse recorte que a substância escolhida passa a existir para o signo como substância da expressão (não é demais ressaltar que a explicação poderia ter utilizado como ilustração o par forma/substância do conteúdo). Há, portanto, um desequilíbrio entre os estratos do signo linguístico, pois a forma da expressão e a forma do conteúdo são pressupostos pelas respectivas substâncias, cuja existência, por esse motivo, pressupõe a existência daquelas formas. E a primazia das formas sobre as substâncias leva Hjelmslev a afirmar que, na verdade, os funtivos da função semiótica não são os planos, mas sim, especificamente, a forma do conteúdo e a forma da expressão.

Isto nos mostra que as duas grandezas que contraem a função semiótica, a expressão e o conteúdo, comportam-se de modo homogêneo em relação a ela: é em virtude da função semiótica, e apenas em virtude dela, que existem esses seus dois funtivos que se pode agora designar com precisão como sendo a forma do conteúdo e a forma da expressão. Do mesmo modo, é em razão da forma do conteúdo e da forma da expressão, e apenas em razão delas, que existem a substância do conteúdo e a substância da expressão, que surgem quando se projeta a forma sobre o sentido, tal como um fio esticado projeta sua sombra sobre uma superfície contínua. (2013, p. $61)$.

Afirmar que a função semiótica tem como funtivos apenas as formas do conteúdo e da expressão, mas não as substâncias que as manifestam, traz implicações sobre a questão da natureza do signo linguístico. Se o signo linguístico é a unidade constituída pela função semiótica e seus funtivos, excluir as substâncias da função semiótica é também afirmar sua 
irrelevância para a definição do conceito de signo. É também dizer que o signo não significa nada além de si, pois é plenamente definido pelas formas que o constituem: pela função semiótica entre formas da expressão e do conteúdo e pela função entre a função semiótica e seus funtivos - duas interdependências. Ou seja, o signo é composto por uma forma da expressão que significa, ou tem como significação, uma forma do conteúdo - duas grandezas que lhe são internas e independentes de qualquer substância extralinguística.

Não obstante a suficiência das formas, Hjelmslev ressalta que, se ainda se quiser dizer que o signo significa outra coisa além de si (além de suas formas), é somente possível dizer que ele significa algo que a função semiótica transformou em substância, ou do conteúdo ou da expressão. "O fato de que um signo é signo de alguma coisa significa, portanto, que a forma do conteúdo de um signo pode compreender essa alguma coisa como substância do conteúdo." (2013, p. 61/62). Contudo, mesmo nessa hipótese o signo só significa uma substância que passou a compor sua estrutura como algo já formado, como substância formada pela forma da expressão ou do conteúdo. De todo modo, o que o signo significa é sempre algo que mantém internamente, uma substância da expressão e uma substância do conteúdo: "Por mais paradoxal que possa parecer, o signo é, portanto, ao mesmo tempo, signo de uma substância de conteúdo e de uma substância da expressão. É neste sentido que se pode dizer que o signo é signo de alguma coisa." (2013, p. 62). Imaginar que o signo signifique de fato algo que lhe é externo seria confundir a língua com uma nomenclatura, com um conjunto de etiquetas, o que Hjelmslev considera um grande engano.

Enfim, convém finalmente comentar sobre a interpretação fenomenológica que encontrei em Hjelmslev sobre o signo linguístico, já um tanto adiantada ainda no final do item sobre a língua.

O signo linguístico é o instrumento empregado pela língua para formar o sentido. A língua forma signos para formar o sentido, e forma o sentido através da formação de signos. $\mathrm{Ou}$ seja, o signo linguístico é algo que a língua usa para alguma finalidade. Desse modo, o ser do signo linguístico mostra-se em si mesmo como um ser-para-a-língua, um ser-instrumental. Em outros termos, pode-se dizer que o signo linguístico se mostra em seu modo de ser como instrumento, como algo que pode ser usado para alguma finalidade. Com isso, se a língua é o conjunto de possibilidades cognoscíveis, todo o conhecimento que é possível acessar, os signos linguísticos são as unidades que delimitam as possibilidades de conhecimento que existem nesse conjunto. 


\title{
Capítulo 3. Roland Barthes.
}

\begin{abstract}
Enfim, de um modo muito mais geral, parece cada vez mais difícil conceber um sistema de imagens ou objetos, cujos significados possam existir fora da linguagem: perceber o que significa uma substância é, fatalmente, recorrer ao recorte da língua: sentido só existe quando denominado, e o mundo dos significados não é outro senão o da linguagem. (2012, p. 12, itálicos no original).
\end{abstract}

O signo é uma fatia (bifacial) de sonoridade, visualidade etc. A significação pode ser concebida como um processo; é o ato que une o significante e o significado, ato cujo produto é o signo. Claro, esta distinção só tem valor classificatório (e não fenomenológico): primeiro, porque a união de significante e significado não esgota, como veremos, o ato semântico, já que o signo vale também por seus contornos; em seguida, porque sem dúvida o espírito, para significar, não procede por conjunção, mas, como veremos, por recorte: na verdade, a significação (semiosis) não une seres unilaterais, não aproxima dois termos, pela simples razão de que significante e significado são, cada um por seu turno, termo e relação. (2012, p. 51, itálicos no original).

\section{a) Preliminarmente}

Roland Barthes foi um dos três primeiros autores selecionados para compor a bibliografia desta dissertação, ao lado de Saussure e Hjelmslev. Mas o que convém dizer é: dentre todos os autores lidos, Barthes foi quem mais me surpreendeu em termos fenomenológicos; fê-lo através de um pequeníssimo capítulo de seu livro O rumor da língua, denominado exatamente de "O rumor da língua". Este capítulo contempla a mais marcante análise sobre o ser da língua de que até então tive conhecimento; com ele, Barthes consolidouse e perpetuou-se dentre os titulares de minha admiração.

\section{b) A língua}

O presente capítulo da dissertação terá uma estrutura peculiar, diferente dos demais. A exígua dimensão do texto de "O rumor da língua" e a vontade de exaltar as palavras enunciadas por Roland Barthes fizeram-me adotar o seguinte método: primeiro citarei um parágrafo do texto para, em seguida, tecer minhas considerações sobre ele, explicando-o em seu conteúdo. Assim, seguir-se-ão citações e comentários até que o texto seja esgotado. Vejamos a primeira, que reproduz o primeiro parágrafo de "O rumor da língua": 
A palavra falada é irreversível, tal é sua fatalidade. Não se pode retomar o que foi dito, a não ser que se aumente: corrigir é, nesse caso, estranhamente, acrescentar. Ao falar, não posso usar borracha, apagar, anular; tudo que posso fazer é dizer "anulo, apago, retifico", ou seja, falar mais. Essa singularíssima anulação por acréscimo, eu a chamarei de "balbucio". O balbucio é uma mensagem duas vezes malograda; por uma parte compreende-se mal; mas, por outra, com esforço, chega-se a compreender apesar de tudo; não está verdadeiramente nem na língua nem fora dela: é um ruído de linguagem comparável à sequência de barulhos pelos quais um motor dá a entender que está mal regulado; tal é precisamente o sentido da rateação, sinal sonoro de uma falha que se delineia no funcionamento do objeto. O balbucio (do motor ou do sujeito) é, em suma, um medo: tenho medo de que a marcha venha a parar. (2004, p. 93, itálicos no original).

Falar é um agir permanente, pois irretratável e imodificável. Uma vez pronunciada, a palavra passa a ser tangível, pois sensível, mas intangível, pois inalterável. A fala, uma vez realizada, é incontrolável. Falar é perder o controle sobre o que se falou. O que foi dito permanece na lembrança, não se pode desdizer. Pode-se somente, como afirma Barthes, dizer que não se queria ter dito, mas para isso novamente se diz. "Apagar” o que se disse é acrescentar ao que se disse, mas sem que se possa apagá-lo. A esse acréscimo praticamente inefetivo, que somente adiciona sem retirar, Barthes conferiu o nome de "balbucio". Balbuciar é demonstrar a falta de controle sobre o que se disse, é dizer que não disse ou que não queria ter dito, é confundir e tornar quase incompreensível o que foi dito e o que se diz acerca do que foi dito. Balbuciar é falar em falso, é falar mal, é falhar ao falar. E falhar ao falar equipara-se, sonoramente, à falha do funcionamento de um motor que rateia, pois é também um ruído, um barulho que entrega o mau-funcionamento. Balbuciar é não evitar ruídos na fala, é provocar tais ruídos e, por isso, temer não conseguir falar, como se teme que um motor que rateia deixe de funcionar, não consiga mais funcionar.

A morte da máquina: ela pode ser dolorosa para o homem se este a descreve como a
de um bicho (ver o romance de Zola). Afinal, por menos simpática que seja a máquina
(porque constitui, sob a figura do robô, a mais grave das ameaças: a perda do corpo),
há entretanto nela a possibilidade de um tema eufórico: o seu bom funcionamento;
tememos a máquina por ela funcionar sozinha, desfrutamos dela por funcionar bem.
Ora, da mesma maneira que as disfunções da linguagem são de certo modo resumidas
num signo sonoro, o balbucio, assim também o bom funcionamento da máquina se
estampa num ser musical: o rumor. (p. 94, itálicos no original).

Tudo que funciona corretamente traz a possibilidade do desfrute, mesmo que também traga algo ameaçador. Se a máquina ameaça a perda do corpo, também permite o desfrute do 
corpo, que desfruta de seu bom funcionamento. Se uma máquina que rateia provoca barulhos, ruídos, semelhantes ao balbuciar da linguagem, uma máquina que funciona deflagra um som de caráter musical. Funcionar bem é ser musical, é não produzir ruídos, é produzir apenas o rumor - que é:

\begin{abstract}
O rumor é o barulho daquilo que está funcionando bem. Segue-se o paradoxo: o rumor denota um barulho limite, um barulho impossível, o barulho daquilo que, funcionando com perfeição, não tem barulho; rumorejar é fazer ouvir a própria evaporação do barulho: o tênue, o camuflado, o fremente são recebidos como sinais de uma anulação sonora.

São então as máquinas felizes que rumorejam. Quando a máquina erótica, mil vezes imaginada e descrita por Sade, aglomerado "pensado" de corpos cujas regiões amorosas estão cuidadosamente ajustadas umas às outras, quando essa máquina põese a funcionar, pelos movimentos convulsivos dos participantes, ela treme e rumoreja levemente; enfim, ela está funcionando, e funcionando bem. Quando os japoneses de hoje se entregam em massa ao jogo das máquinas caça-níqueis (chamadas lá de Pachinko), em grandes halls, estes se enchem de um enorme rumor de bolinhas, e este rumor significa que alguma coisa, coletivamente, funciona: o prazer (enigmático por outras razões) de jogar, de fazer o corpo agir com exatidão. Porque o rumor (vê-se pelo exemplo de Sade e pelo exemplo japonês) implica uma comunidade de corpos: nos ruídos do prazer que "funciona", nenhuma voz se eleva, conduz ou se afasta, nenhuma voz se constitui; o rumor é o próprio ruído do gozo plural - mas de nenhum modo maciço (a massa, pelo contrário, tem uma só voz, terrivelmente forte). (p. 94/95, itálicos no original).
\end{abstract}

O rumor é a ausência de ruídos, é a ausência de barulho. Produzir um rumor é rumorejar o bom funcionamento, é aniquilar qualquer barulho. Uma máquina que funciona bem soa também bem, soa com perfeição: rumoreja. Rumorejar é soar de forma agradável, apreciável. Barthes diz que são as máquinas felizes que rumorejam, e rumorejam porque funcionam adequadamente, sem percalços ou falhas. Enquanto rumorejam, ensejam o gozo, ensejam que do seu usufruto advenha o gozo, o gozo pelo bom-funcionamento. O rumor das máquinas aniquila qualquer barulho, de si e daqueles que se valem de si, criando um só rumor, sincrônico e harmonioso, apesar de terrivelmente forte.

Mas se as máquinas balbuciam e rumorejam, também a língua, que balbucia, poderia rumorejar?

E a língua, pode rumorejar? Falada, ela permanece, parece, condenada ao balbucio; escrita, ao silêncio e à distinção dos signos: de qualquer modo, fica ainda demasiado sentido para que a linguagem realize um gozo que seria próprio à sua matéria. Mas o que é impossível não é inconcebível: o rumor da língua forma uma utopia. Que utopia? A de uma música do sentido; com isso quero dizer que em seu estado utópico a língua 
seria ampliada, eu diria mesmo desnaturada, até formar uma imensa trama sonora em que o aparelho semântico se acharia irrealizado; o significante fônico, métrico, vocal, se desfraldaria em toda a sua suntuosidade, sem que jamais dele se despegasse um signo (viesse a naturalizar esse puro lençol de gozo), mas também - e aí está o mais difícil - sem que o sentido seja brutalmente dispensado, dogmaticamente excluído, enfim castrado. Rumorejante, confiada ao significante por um movimento inaudito, desconhecido de nossos discursos racionais, nem por isso a língua deixaria um horizonte do sentido: o sentido, indiviso, impenetrável, inominável, seria no entanto posto longe como uma miragem, fazendo do exercício vocal uma paisagem dupla, munida de um "fundo"; mas em lugar de a música dos fonemas ser o "fundo" das nossas mensagens (como acontece na nossa Poesia), o sentido seria aqui o ponto de fuga do gozo. E da mesma forma que atribuído à máquina, o rumor não é mais que o ruído de uma ausência de ruído, referido à língua, ele seria esse sentido que faz ouvir, uma isenção de sentido, ou - é a mesma coisa - esse não-sentido que faria ouvir ao longe o sentido agora liberto de todas as agressões de que o signo, formado na "triste e selvagem história dos homens", é a caixa de Pandora.

É sem dúvida uma utopia; mas a utopia é que muitas vezes guia as pesquisas de vanguarda. Existem pois, aqui e ali, por instantes, o que se poderia chamar de experiências de rumor: tais são algumas produções da música pós-serial (é muito significativo que essa música dê uma importância extrema à voz: é a voz que ela trabalha, buscando desnaturar nela o sentido, mas não o volume sonoro), certas pesquisas de radiofonia; tais ainda os últimos textos de Pierre Guyotat ou de Philippe Sollers. (p. 95/96, itálicos no original).

A possibilidade do rumor da língua é um tanto embaraçada por suas duas formas de manifestação: a fala e a escrita. Quando é falada, a língua apresenta-se predominantemente dominada pelo balbucio, impregnada de ruídos decorrentes de um mau-funcionamento. Quando é escrita, não soa, é quieta e silenciosa e, por isso, parece não poder rumorejar. O rumorejar da língua, portanto, é dificultado pela natureza balbuciante da fala e pela natureza calada da escrita. A possibilidade aproxima-se de uma impossibilidade.

Essas dificuldades levam Barthes a desacreditar num estado duradouro no qual a língua apenas rumorejaria, sem falhas e ruídos. Tal estado, um rumor perdurável de língua, é para ele uma utopia. Utopia não apenas pelo balbuciar da fala e pela quietude da escrita, mas também pela imensidão de sentido vinculado a cada uma dessas matérias - a sonora e a escrita. O sentido impede o rumor pois desprestigia o significante. O significante vinculado ao sentido carece de perfeição porque contrai uma função: a função de significar que lhe é imposta pelos signos. O significante que significa o sentido não é livre, é delimitado pelos signos e não pode rumorejar, mas apenas significar.

Não obstante, Barthes diz que momentos de rumor não são inconcebíveis para a língua; é sim possível que momentaneamente o significante apresente-se completamente desvinculado, de delimitações e de significações; que se apresente pleno, monumentalmente pleno, autonomamente pleno. Em tais momentos, o significante soa como uma música contínua, sem 
que nela seja possível identificar um signo sequer e, por isso, qualquer sentido previamente imputado. O significante apenas soa, perfeita e prazerosamente soa.

Mas Barthes alerta para o fato de que, nessa sonância espontânea, o sentido não é de todo eliminado, mas apenas afastado; o sentido ainda existe, porém, não vinculado ao significante. O significante rumoreja por rumorejar, mas nesse rumorejar essencialmente rumorejante, pode despertar um sentido qualquer, um sentido que, de tão incerto, mostra-se distante, porém belo e desejável - por isso Barthes emprega a metáfora da miragem. O rumor da língua faz sentido porque não quer fazer sentido; é sua falta de sentido que lhe traz um sentido: o sentido do gozo decorrente da perfeição, decorrente do bom-funcionamento. O rumor da língua proporciona o gozo, e o gozo sempre tem algum sentido para aquele que goza, um sentido não previamente estabelecido (ou agredido, como diz Barthes) por qualquer signo, ou por qualquer forma linguística, mas um sentido inexplicável e ingênuo e, talvez por isso, emocionante e belo.

\begin{abstract}
Muito mais, essa pesquisa em torno do rumor, podemos nós mesmo levá-la a efeito, e na vida, nas aventuras da vida; no que a vida nos traz de maneira inopinada. Noutra noite, ao assistir ao filme de Antonioni sobre a China, experimentei de repente, na virada de uma sequência, o rumor da língua: numa rua de aldeia, algumas crianças, encostadas a um muro, leem em voz alta, cada um para si, todos juntos, um livro diferente; aquilo rumorava da melhor maneira, como uma máquina que funcionasse bem; o sentido era para mim duplamente impenetrável, por desconhecimento do chinês e pelo emaranhamento dessas leituras simultâneas; mas eu ouvia, numa espécie de percepção alucinada, tão intensamente recebia ela toda a sutileza da cena, eu ouvia a música, o sopro, a tensão, a aplicação, enfim, algo como uma meta. Quê! Basta falarem todos juntos para fazer rumorejar a língua, da maneira rara, impregnada de gozo, de que se acabou de falar? De jeito algum, claro; para a cena sonora é preciso uma erótica (no sentido mais amplo do termo), o impulso, ou a descoberta, ou o simples acompanhamento de emoção: o que era trazido justamente pelo rosto dos meninos chineses. (p. 96/97, itálicos no original).
\end{abstract}

Certa vez uma tia me relatou que, apesar de não possuir qualquer domínio sobre a língua inglesa, emocionou-se de forma indescritível quando ouviu The Beatles pela primeira vez; apesar de não compreender o que cantavam, foi tocada pela emoção com que a música era cantada - ela certamente viveu um desses raros momentos rumorejantes da língua. E também tenho um relato pessoal: a primeira vez em que ouvi "eu te amo" de minha namorada foi um momento inesquecível e indefinível; eu realmente não saberia como descrever aquele brevíssimo, mas longo instante. O que me tocou não foi o sentido conjunto dessas três palavras - se é que elas são capazes de traduzir qualquer sentido de amor - mas o sentido que senti ao 
presenciar a emoção e a serenidade com que tais palavras me foram ditas. Eu, sem dúvida alguma, vivenciei o rumor da língua.

É ainda interessante notar o modo como Barthes qualifica esse sentido peculiar despertado pelo rumor da língua. No parágrafo acima, atribuiu-lhe o caráter de algo verdadeiramente novo, que não necessariamente se compreende, mas se descobre, além de excitar, emocionar ou impulsionar. Ou seja, o rumor da língua permite a vivência de uma experiência nunca experimentada. Diante disso, convém questionar: seria possível buscar o rumor e experimentar o que proporciona de novo intencionalmente? Isto é, conscientemente?

\footnotetext{
Fico imaginando hoje, um pouco à moda do grego antigo, tal como o descreve Hegel: interrogava, diz ele, com paixão, sem esmorecimento, o rumor das folhagens, das fontes, dos ventos, enfim, o estremecer da Natureza, para ali captar o desenho de uma inteligência. E eu, é o estremecer do sentido que interrogo escutando o rumor da linguagem - dessa linguagem que é a minha Natureza, homem moderno.
}

A resposta à questão acima colocada não aparece de forma clara - e talvez nem deva existir além da imaginação deste que escreve. Mas parece certo que Barthes tem consciência, pois já vivenciou experiências, do rumor da língua. Parece também certo que se propôs investigar o sentido gerado pelo rumor, mas não é minimamente certa sua capacidade de provocar o rumor sempre que desejado. Pelo contrário, Barthes parece procurar momentos de rumor para então acessar, ainda que rapidamente, seu sentido; por isso compara a atividade a que se dedica à atividade realizada pelos gregos antigos - o interrogar o sentido (a inteligência) do que se contempla. Se os gregos antigos buscavam uma inteligência nos diversos rumores da Natureza, Barthes persegue a inteligência presente no rumor da língua, que é a sua Natureza, a única Natureza posta para nós, o homem moderno.

Acredito que há, nesse fabuloso texto de Barthes, duas interpretações sobre o modo de ser da língua: uma sobre seu modo de ser habitual e outra sobre seu modo de ser rumorejante.

Em seu estado habitual, a língua não passa de um ente que funciona mal, que balbucia quando falada ou silencia quando escrita. Normalmente, a língua não promove algo novo, um sentido original, nada impulsiona ou mesmo emociona. É meramente significação, é um apanhado de signos que aprisionam a suntuosidade do significante e agridem o sentido. Portanto, nesse estado habitual, o ser da língua mostra-se em si mesmo como aprisionamento, como ser-aprisionante. Sendo, a língua mostra-se em seu modo de ser como o aprisionamento do significante ao sentido. O significante torna-se assim funcional: serve para significar um 
sentido, mas, nessa função, não pode funcionar bem. Por outro lado, o sentido que é amarrado ao significante, torna-se acessível, mas repetitivo, trivial, e, por esse motivo, nãoimpressionante, não-contemplável, não-gozável.

Quando, contudo, raramente rumoreja, a língua impressiona e emociona, funciona. Funcionando, satisfaz, permite o gozo e revela um sentido novo - é no rumor da língua que o inédito se anuncia. O rumor da língua mostra-se como a possibilidade de uma nova inteligência; é, realmente, a única possibilidade de uma nova inteligência, a possibilidade que se apresenta ao homem moderno, o prisioneiro dessa natureza que considera nova: a língua e, mais amplamente, a linguagem. Quando rumoreja, o ser da língua mostra-se em si mesmo como erotismo, como ser-erótico. Sendo, a língua rumorejante mostra-se em seu modo de ser como uma erótica, como permissão ao despertar das paixões, do gozo, da descoberta, do que é excitante; permite o despertar de um sentido que faz sentido porque não tem um sentido (criado pelas agressões dos signos da língua habitual).

\section{c) E o signo linguístico}

No tópico anterior, foi notável o papel que Barthes atribuiu ao signo linguístico: o papel de responsável pelo aprisionamento da manifestação material do significante linguístico e pela agressiva trivialização do sentido. Com a presença do signo, a fala e a escrita não podem ocorrer de forma livre e desabrochada, mas somente numa sequência de unidades previamente delimitadas. A delimitação em unidades é executada para imputar ao significante a função de significar um sentido sempre certo e definido (nada extraordinário ou inalcançável, como o sentido despertado pelo raro rumorejar linguístico). Mas, ao exercer essa função, o significante ocorre sempre agrilhoado e, com isso, não consegue funcionar bem, apenas balbuciar.

O signo é, portanto, protagonista no interior da língua que balbucia. É o signo que estrutura as unidades da manifestação (a fala e a escrita) e promove a significação (isto é, a amarração do sentido ao significante).

E é especialmente a significação que desperta a questão cuja resposta será o tema do presente tópico sobre o signo linguístico: como ocorre a significação? Responder a como ocorre a significação é explicar como o signo realiza a vinculação entre o sentido que agrediu e o significante que aprisionou. Ou seja, é esclarecer como o signo prende o significante seccionado ao sentido certo e trivializado, sempre acessível no interior da língua que balbucia. 
Barthes buscou explicar a significação recorrendo ao conceito de "imaginação do signo"26. A "imaginação do signo" é o ato de imaginar o modo como ocorre a construção do sentido através do signo; é imaginar como ocorre a significação. Segundo Barthes, há três diferentes formas de imaginar a construção do sentido (de imaginar o signo); e cada uma delas busca fazê-lo através da acentuação de uma dentre as três relações que são implicadas pelo signo. Imaginar o signo é, por conseguinte, dizer que a significação surge a partir de uma das três relações por ele implicadas. Mas quais são essas três relações? Vejamo-las.

A primeira, de caráter interno, é a que une um significante a um significado; a segunda, de caráter externo, liga o signo a um repertório de signos de onde é extraído para ocupar uma posição no discurso; e, a terceira, também de caráter externo, ilustra a situação do signo no discurso, alinhado a outros signos que o antecedem e o sucedem.

Todo signo inclui ou implica três relações. Primeiramente uma relação interior, a que une seu significante a seu significado; em seguida, duas relações exteriores: a primeira é virtual, ela une o signo a uma reserva específica de outros signos, da qual o destacamos para inseri-lo no discurso; a segunda é atual, junta o signo aos outros signos do enunciado que o precedem ou lhe sucedem. (1999, p. 41).

A relação existente entre significante e significado é denominada de simbólica. $\mathrm{O}$ simbolismo é a correlação mais ou menos analógica entre significante e significado: o significante, que é a forma, assemelha-se, em maior ou menor medida, ao significado, que é o conteúdo.

O primeiro tipo de relação aparece claramente no que se chama geralmente de símbolo; por exemplo, a cruz "simboliza" o cristianismo, o muro dos Federados "simboliza" a Comuna, o vermelho "simboliza" a proibição de passar; chamaremos pois essa primeira relação de relação simbólica, se bem que a encontremos não só nos símbolos, mas também nos signos (que são, por assim dizer, símbolos puramente convencionais). (1999, p. 41/42, itálicos no original).

A consciência simbólica vê o signo em sua dimensão profunda, poder-se-ia quase dizer: geológica, já que a seus olhos é a superposição do significado e do significante que constitui o símbolo; existe a consciência de uma espécie de relação vertical entre a cruz e o cristianismo: o cristianismo está sob a cruz, como uma massa profunda de crenças, de valores e de práticas mais ou menos disciplinadas ao nível de sua forma. A verticalidade da relação traz duas consequências: por um lado, a relação vertical tende a parecer solitária: o símbolo parece manter-se de pé no mundo, e mesmo quando se afirma que ele abunda, é sob a forma de uma "floresta", isto é, de uma

\footnotetext{
${ }^{26}$ Que foi apresentado no capítulo “A imaginação do signo”, do livro Crítica e Verdade (1999).
} 
justaposição anárquica de relações profundas que não se comunicariam, por assim dizer, senão por suas raízes (os significados); e, por outro lado, essa relação vertical aparece forçosamente como uma relação analógica: a forma se parece (mais ou menos, mas sempre um pouco) com o conteúdo, como se ela fosse em suma produzida por ele, de modo que a consciência simbólica recobre talvez por vezes um determinismo mal liquidado: existe pois o privilégio maciço da semelhança (mesmo quando se sublinha o caráter inadequado do signo). (1999, p. 43, itálicos no original).

O semiólogo que prestigia essa relação entre significante e significado, definida por Barthes como vertical, tende a observar os signos de forma isolada, como elementos autônomos e bastantes por si, que, se chegam a relacionar-se, fazem-no por conexões decorrentes do significado, jamais do significante. É essa perspectiva simbólica que mais prestigia o significado como elemento formador do signo e, consequentemente, do sentido. O sentido nasce com a união entre significante e significado, contudo, nessa união, o significante é algo apenas secundário, já que sua existência enquanto forma é determinada pela existência do significado.

(...) essa consciência permanece entretanto típica enquanto o olhar analítico não se interessa (quer as ignore, quer as conteste) pelas relações formais dos signos entre si, pois a consciência simbólica é essencialmente recusa da forma; no signo, é o significado que interessa: o significante nunca é para ela mais do que um determinado. (1999, p. 44).

A relação simbólica, portanto, fundamenta a significação numa relação definida por Barthes como analógica. Como a analogia é regida pelo conteúdo, que determina o significante, não há considerações formais incluídas nessa hipótese de imaginação do signo. Há a regência primária do conteúdo (cada signo possui seu próprio e distinto conteúdo) e um significante determinado em sua forma pelo conteúdo (mais ou menos semelhante ao conteúdo). Cada signo define-se por si e apenas por si, independentemente de qualquer outro signo.

Quando então o semiólogo passa a se interessar pelas relações formais implicadas pelo signo linguístico, consegue visualizar aquelas denominadas de exteriores. A primeira delas - a relação que o signo mantém com os demais signos de um sistema (de signos) no qual encontrase inserido - é chamada de paradigmática: “(...) esse plano de relação é pois o do sistema, às vezes chamado de paradigma; chamaremos pois esse segundo tipo de relação de relação paradigmática." (1999, p. 42, itálicos no original). Nessa perspectiva semiológica, o sentido não é mais o fruto da relação entre significante e significado, mas o resultado das relações formais que os signos, por serem distintos, mas minimamente semelhantes, mantêm entre si. 
A consciência paradigmática define pois o sentido, não como o simples encontro de um significante e um significado, mas, segundo a bela expressão de Merleau-Ponty, como uma verdadeira "modulação de coexistência", ela substitui a relação bilateral da consciência simbólica (mesmo se essa relação é multiplicada), por uma relação (pelo menos) quadrilateral, ou mais exatamente, homológica. (1999, p. 44).

A consciência paradigmática, pelo contrário, é uma imaginação formal; ela vê o significante ligado, como que de perfil, a alguns significantes virtuais dos quais ele está ao mesmo tempo próximo e distinto; ela não vê mais (ou vê menos) o signo em sua profundidade, ela o vê em sua perspectiva; assim a dinâmica que está ligada a essa visão é a de um chamado: o signo é citado fora de uma reserva finita, ordenada, e esse chamado é o ato soberano da significação: imaginação de agrimensor, de geômetra, de proprietário do mundo, que aí está à vontade, já que o homem, para significar, só tem de escolher no que lhe é apresentado já estruturado, quer por seu cérebro (na hipótese binarista), quer pela finidade material das formas. (1999, p. 46, itálicos no original).

O sentido, destarte, segundo a hipótese paradigmática de imaginação do signo, deriva essencialmente da intermodulação provocada pela coexistência inter-relacional dos signos no paradigma (apesar de só vir a desabrochar no interior do discurso, após o exercício do ato de significação que seleciona, a cada vez, um dentre outros signos existentes no paradigma).

E é no interior do discurso que aparece a terceira relação implicada pelo signo, denominada de sintagmática. A manifestação cria o discurso como um encadeamento de signos, e esse encadeamento recebe o nome de sintagma. No interior do discurso, ou no interior do sintagma, o signo apresenta-se em relação com os signos que o antecedem e com os signos que o sucedem. Com isso, a imaginação do signo que se fundamenta na relação sintagmática para explicar o nascimento do sentido interessa-se pelas restrições e pelas possibilidades de alinhamento dos signos na manifestação discursiva.

A consciência sintagmática é consciência das relações que unem os signos entre si no nível do próprio discurso, isto é, essencialmente, constrangimentos, tolerâncias e liberdades de associação do signo. Essa consciência marcou os trabalhos linguísticos da escola de Yale, e, fora da linguística, as pesquisas da escola formalista russa, principalmente as de Propp no domínio do conto popular eslavo (por isso se pode admitir que ela esclareça um dia a análise das grandes "narrativas" contemporâneas, da notícia de jornal ao romance popular). (1999, p. 45).

A imaginação sintagmática não vê mais (ou vê menos) o signo em sua perspectiva, ela o prevê em sua extensão: suas ligações antecedentes ou consequentes, as pontes que ele lança em direção a outros signos; trata-se de uma imaginação "estemática", a da cadeia ou da rede; assim a dinâmica da imagem é aqui a do arranjo de partes móveis, substitutivas, cuja combinação produz sentido, ou mais geralmente um objeto 
novo; trata-se pois de uma imaginação propriamente fabricativa, ou ainda funcional (...). (1999, p. 46/47, itálicos no original).

Por conseguinte, a hipótese sintagmática de imaginação do signo busca explicar o nascimento do sentido a partir das combinações de signos que ocorrem no discurso. São as combinações entre os signos que produzem o sentido. E o local onde as combinações de signos ocorrem é o discurso, o sintagma que forma o discurso; logo, o discurso é local do nascimento do sentido.

É por uma dessas três perspectivas apresentadas por Barthes que o semiólogo pode compreender e explicar o nascimento da significação, o nascimento do sentido. Mas, paradoxalmente, o nascimento do sentido nada mais representa que sua trivialização. Ao nascer pelo signo, o sentido torna-se estático e certo, acessível e previsível: trivial. O nascimento não promove a liberdade, mas a agressão imediata. O nascimento do sentido é um mero surgir para a língua, mas não um vir-à-luz... não há nada de luminoso no balbuciar.

E se a língua que balbucia é a língua que aprisiona o significante e agride o sentido, aprisiona-o e agride-o exatamente por meio do signo linguístico. É o signo que instrumentaliza o balbuciar da língua; é o signo que serve para aprisionar o significante em unidades delimitadas enquanto transforma agressivamente o sentido em algo significável por unidades delimitadas. E esse servir-para é o que, para mim, revela a interpretação fenomenológica que Barthes faz acerca do ser do signo linguístico: o signo serve à língua, mostra-se em seu modo de ser como instrumento à disposição da língua. Ou seja, o ser do signo mostra-se em si mesmo como instrumentalidade, como ser-para algo, para uma finalidade; mostra-se como ser-para-alíngua. $\mathrm{O}$ signo serve à língua, que o cria para delimitar unidades significantes e determinar agressivamente o sentido.

Contudo, não é demais ressaltar que, se o signo linguístico serve à língua, serve exclusivamente à língua em seu estado usual, em seu estado de balbucio. Afinal, se no balbuciar o signo domina e predomina, incorpora tudo que possui um sentido ao atribuir um sentido a tudo; no rumor, o signo se esvai e o significante se liberta, e o sentido torna-se inalcançável, pois incerto e indelimitado, porém... apreciável, desejável e, sobretudo, gozável. A língua que rumoreja não apresenta signos, pois, ao rumorejar, liberta o sentido... ao libertar-se num sentido todo especial. 


\title{
Capítulo 4. Umberto Eco.
}

\begin{abstract}
Tomemos então uma língua como um sistema de regras: não apenas as gramaticais, mas também as hoje assim chamadas pragmáticas; por exemplo, a regra de conversação que à pergunta se responde de modo pertinente, e quem a viola é julgado, a cada vez, mal-educado, bobo, provocador, ou se crê que esteja aludindo a alguma outra coisa que não quer dizer. A literatura, que trapaceia com a língua, apresenta-se como atividade que desagrega as regras e propõe outras: provisórias, válidas no âmbito de um discurso único e de uma só corrente; e sobretudo válidas no âmbito do laboratório literário. Isso significa que Ionesco trapaceia com a língua fazendo suas personagens falarem como falam, por exemplo, na Cantora careca. Mas se no relacionamento social todos falassem como a cantora careca, a sociedade se desagregaria. Note-se que não se teria revolução linguística, porque a revolução implica a reviravolta das relações de poder; um universo que fala como Ionesco não derrubaria nada, instauraria uma espécie de grau $n$ (oposta a zero, um número indefinido) do comportamento. Nem seria mais possível sequer comprar pão do padeiro.

Como a língua se defende desse risco? Barthes o diz, reconstituindo uma situação de poder diante da própria violação, absorvendo-a (o anacoluto do artista torna-se norma comum). Quanto à sociedade, essa defende a língua recitando a literatura, que põe em questão a língua, em lugares determinados. Assim dá-se que na língua nunca se tem revolução: ou é revolução simulada, sobre um palco, onde tudo é permitido, depois volta-se para casa falando do jeito normal; ou é movimento infinitesimal de reforma contínua. O estetismo consiste em acreditar que a arte seja a vida e a vida arte, confundindo as zonas. Iludindo-se. (1984, p. 328/329, itálicos no original).
\end{abstract}

\section{a) Preliminarmente}

Conheci Umberto Eco um tanto antes que a linguística. Já me esforcei bastante, mas não consigo lembrar em qual livro de Direito uma vez encontrei citada sua $A$ estrutura ausente. Numa época em que buscava acumular livros interessantes, comprei-a, juntamente com $A s$ formas do conteúdo - indicada no site da loja virtual como a continuação da primeira. Estes dois livros permaneceram guardados e intocados até o começo do ano passado (dois mil e dezoito) e foram comprados mais ou menos uma semana antes da notícia da morte de Eco (logo no começo de dois mil e dezesseis). Em um intervalo tão curto, passei do desconhecimento de sua vida para a lamentação de sua morte; e em um intervalo tão longo, por dois anos guardei-o em minha estante. Ainda bem! Tivesse lido-o antes, sem dúvida nada teria compreendido - se é que hoje posso dizer que o compreendo. E, felizmente, não corri o risco, consciente ou inconsciente, de afastá-lo por não o compreender. Afinal, não raro, coisas são rechaçadas como não-interessantes quando, na verdade, são não-compreendidas, por limitação de quem se propôs compreendê-las. 
Enfim, sequer sei como elogiá-lo. Qualquer tentativa de elogio, talvez, já seria minguar a admiração que sinto. Hoje, lamento como nunca o fato de jamais poder conhecê-lo; e espero que minhas palavras contribuam, ainda que infimamente, para a teoria semiótica que desenvolveu, a inestimável herança que nos deixou com sua passagem para o não-semiotizável.

\begin{abstract}
Comumente falamos numa coisa chamada/Alpha centauri/ mas sem jamais tê-la experimentado. Com algum estranho aparelho, um astrônomo passou alguma vez por essa experiência. Mas nós não conhecemos esse astrônomo. Conhecemos apenas uma unidade cultural que nos foi comunicada através de palavras, desenhos, ou de outros meios. Em defesa ou pela destruição dessas unidades culturais (como de outras, tais como /liberdadel, Itransubstanciação/ ou /mundo livre/), estamos dispostos até mesmo a enfrentar a morte. Quando a morte chega, e só depois dela, ela é o único referente, o único evento não-semiotizável (um semiótico morto não mais comunica teorias semióticas). Mas até um instante atrás é ela usada quando muito como unidade cultural. (2010, p. 15, itálicos no original).
\end{abstract}

Enquanto semiótico morto, talvez não possa mesmo mais comunicar. Não obstante, não tenho dúvidas de que o que uma vez comunicou enquanto semiótico vivo manter-se-á perene, como se continuasse a ser repetida e teimosamente comunicado a cada nova leitura. $\mathrm{E}$ talvez seja por isso que teorizamos, e talvez seja por isso que escrevemos.

\title{
b) A língua
}

Códigos e mais códigos...

O capítulo quarto do livro Interpretação e superinterpretação, de Umberto Eco (2018), é a transcrição da fala que Richard Rorty proferiu nas Conferências Tanner de 1990. Em algum momento de seu discurso, Rorty revelou a frustração que sentira ao ler os últimos escritos do semioticista italiano, pois "esperava que Eco se mostrasse ao menos um pouco menos apegado à noção de ‘código' do que estivera ao escrever, no início dos anos 70, $A$ Theory of Semiotics." (2018, p. 116) ${ }^{27}$.

Quão pretencioso foi Rorty. O conceito de código constitui a principal fundação da semiótica de Eco e, assim sendo, dificilmente seria abandonado, ainda que após um intervalo de aproximadamente vinte anos. Essa permanência, que Rorty denominou negativamente de "apego", mostra-se, na verdade, como algo positivo; mostra-se como o resultado de uma

\footnotetext{
${ }^{27}$ A theory of semiotics é o título inglês do Tratado Geral de Semiótica.
} 
consistência teórica; isto é, o conceito de código continuou sendo adotado porque manteve-se suficiente para explicar o funcionamento dos fenômenos comunicativos como um todo.

Mas, afinal, o que são tais códigos? E qual sua relação com a língua?

O primeiro contato com esse conceito é um tanto aterrorizante, pois Eco define-o de maneira extremamente sucinta: “(...) chamaremos de código em sentido próprio a regra que associa os elementos de um s-código aos elementos de um outro s-código ou de mais s-códigos (...).” (2014, p. 30, itálicos no original). Essa definição, que parece nada definir, é ainda complicada pela adoção de um novo conceito problematicamente denominado de "s-código". Remanesce, portanto, a questão inicial, porém ampliada: o que são códigos e o que são scódigos? À definição de s-códigos, Eco dedica algumas palavras mais:

\begin{abstract}
Os s-códigos são, na verdade, SISTEMAS ou ESTRUTURAS que podem muito bem subsistir independentemente do propósito significativo ou comunicativo que os associa entre si, e, como tais, podem ser estudados pela teoria da informação ou pelos vários tipos de teorias generativas. Eles são compostos por um conjunto finito de elementos estruturados oposicionalmente e governados por regras combinatórias mediante as quais podem dar origem a liames finitos ou infinitos. (2014, p. 30).
\end{abstract}

Portanto, o s-código é um sistema (e, daqui em diante, será chamado apenas de sistema) composto por (a) um conjunto de elementos que mantêm relações de oposição entre si e por (b) regras internas que regem a combinação desses elementos.

A explicação da definição do conceito de sistema deve agora facilitar o manuseio do conceito de código. Para tanto, é imprescindível ressaltar que Eco, quando se refere ao conceito de código, refere-se a todos os códigos possíveis; ou seja, refere-se desde códigos comunicacionais mais básicos, que associam os elementos de um sistema de sinais (estímulos) aos elementos de um sistema de respostas ${ }^{28}$, até os mais complexos, como a língua, que associam os elementos de um sistema de expressão a elementos de um sistema de conteúdo

No interior da definição que Eco confere ao conceito de código inaugura-se uma oposição relevantíssima, uma oposição entre o que é semiótico e o que não é semiótico. Ao promover a associação dos elementos de ao menos dois sistemas, o código pode motivar o surgimento de relações de sinal e resposta (não-semiótico) ou o surgimento de relações de caráter significativo (semiótico). No primeiro caso, os sinais não têm significado, pois são

\footnotetext{
${ }^{28}$ Um exemplo de código que relaciona elementos de um sistema de estímulos a um sistema de respostas é dado por Eco no capítulo n. 1 do Tratado geral de semiótica (2014, p. 25/38).
} 
empregados no interior de um processo comunicativo para solicitar uma reação do receptor, uma resposta previamente programada. No segundo caso, o código qualifica os elementos de um sistema como expressões possíveis dos elementos de um outro sistema, qualificados como conteúdos expressáveis pelos elementos do primeiro sistema. A relação expressão-conteúdo é significativa porque a expressão carrega um conteúdo: "Quando um código associa os elementos de um sistema veiculante aos elementos de um sistema veiculado, o primeiro se torna a expressão do segundo, o qual, por seu turno, torna-se o conteúdo do primeiro.” (2014, p. 39, itálicos no original). Ou seja, ao contrário do estímulo, a expressão não solicita uma resposta do receptor, mas lhe transmite um conteúdo.

Resumidamente, pode-se também dizer que numa relação sinal-resposta, o receptor deve conhecer o código para reagir à mensagem; já numa relação de expressão-conteúdo, o receptor deve conhecer o código para compreender a mensagem. Aqui, novamente, é importantíssimo lembrar que Eco está a se referir a qualquer tipo de código e, portanto, a qualquer tipo de emissor e de receptor que, não necessariamente, serão humanos, podendo ser, por exemplo, duas máquinas (o que facilita a visualização de um sistema sinal-resposta).

\begin{abstract}
Agora já podemos distinguir um sinal de um signo. Um sinal é a unidade pertinente de um sistema que pode tornar-se um sistema de expressão ordenado de um conteúdo, mas que também poderia permanecer um sistema de elementos físicos privados de função semiótica (que, como tal, é estudado por uma teoria da informação em sentido restrito). Um sinal pode ser um estímulo que não significa nada, mas provoca ou solicita algo: contudo, quando usado como ANTECEDENTE reconhecido de um CONSEQUENTE previsto, é assumido como signo, pois fica em lugar do próprio consequente (para o emissor ou para o destinatário). (2014, p. 39).
\end{abstract}

A associação existente entre um elemento de um sistema de expressão e um elemento de um sistema de conteúdo é denominada por Eco de "função sígnica": "Há função sígnica quando uma expressão se correlaciona a um conteúdo, tornando-se ambos os elementos correlatos funtivos da correlação." (2014, p. 39, itálicos no original). E se a função sígnica é a correlação existente entre os dois funtivos, expressão e conteúdo, o todo formado pelos dois funtivos e a função que os correlaciona é denominado de signo: "Um signo é sempre constituído por um (ou mais) elementos de um PLANO DA EXPRESSÃO convencionalmente correlatos a um (ou mais) elementos de um PLANO DO CONTEÚDO.” (2014, p. 39$)^{29}$.

\footnotetext{
${ }^{29}$ É importante notar que Eco emprega "plano da expressão" como sinônimo de sistema de expressão e "plano do conteúdo" como sinônimo de sistema de conteúdo.
} 
A relação entre código e função sígnica mostra-se como uma relação entre instrução e execução ${ }^{30}$. O código contempla todas as possibilidades de função sígnica, já que contempla todas as possibilidades de correlação entre funtivos de expressão e de conteúdo. E a função sígnica é a efetivação de tais possibilidades de associação previstas pelo código. $O$ código instrui acerca das possibilidades possíveis, a função sígnica surge da execução de tais possibilidades.

Portanto, (a) um código estabelece a correlação de um plano da expressão (no seu aspecto puramente formal e sistemático) com um plano do conteúdo (no seu aspecto puramente formal e sistemático); (b) uma função sígnica estabelece a correlação entre um elemento abstrato do sistema da expressão e um elemento abstrato do sistema do conteúdo; (c) dessa forma, um código estabelece TIPOS gerais, produzindo assim a regra que gerará TOKENS ou OCORRÊNCIAS CONCRETAS, a saber, aquelas unidades que se realizam nos processos comunicativos e que comumente se chamam signos; (...). (2014, p. 41/42).

Mas há mais. O código, além de regrar as possibilidades de realização da função sígnica, também estabelece as regras de combinação de funções sígnicas nos processos comunicativos. Em outras palavras, o código regula a produção de funções sígnicas e também a forma como serão posicionados na mensagem comunicável. Por isso, deve-se “(...) conceber o código como uma dupla entidade que estabelece de um lado correlações semânticas e de outro regras de combinabilidade sintática.” (2014, p. 79). As correlações semânticas são as funções sígnicas, isto é, as correlações entre funtivos (elementos do plano da expressão e elementos do plano do conteúdo) que formam os signos; e a combinabilidade sintática é o conjunto de possibilidades de combinação de funções sígnicas no interior do processo comunicativo, no interior da mensagem que será comunicada.

Enfim, código é o conjunto de regras que determinam as possibilidades de formação de funções sígnicas e as possibilidades de combinação para formação de mensagens complexas que serão comunicadas.

Pensando agora finalmente sobre a língua, não é difícil defini-la como um código, pois associa elementos de um plano de expressão a elementos de um plano do conteúdo ensejando a formação de funções sígnicas. Contudo, ao analisar a língua, Eco nela identifica um potencial

\footnotetext{
30 A partir daqui, por opção metodológica, não mais falarei de códigos que associam sistemas de estímulos a sistemas de respostas, mas apenas de códigos que relacionam sistema de expressão e sistemas de conteúdo. Consequentemente, sempre que o termo "código" for empregado será para significar: regra que associa sistemas de expressão a sistemas de conteúdo.
} 
não apenas associativo, mas verdadeiramente criativo. Vejamos como essa criatividade é proposta na seguinte passagem de $A$ busca da língua perfeita ${ }^{31}$ :

\begin{abstract}
Ao examinar as estruturas das diferentes línguas obviamente originais ou artificiais com que nos vamos deparar, será necessário compará-las com uma noção teoricamente rigorosa de estrutura de uma língua natural. Para esse fim nos ateremos ao modelo hjelmsleviano (Hjelmslev, 1943), ao qual faremos referência para cada língua que tomaremos em exame.

Uma língua natural (e em geral qualquer sistema semiótico) é composto de um plano de expressão (para uma língua natural diríamos por um léxico, uma fonologia, e uma sintaxe), e por um plano de conteúdo, que representa o universo dos conceitos que podemos exprimir. Cada um destes planos é composto de forma e substância e ambos resultam da organização de uma matéria ou de um continuum.

Em uma língua natural a forma da expressão é constituída pelo seu sistema fonológico, por um repertório lexical, e pelas suas regras sintáticas. Por meio desta forma podemos gerar várias substâncias de expressão, como as palavras que pronunciamos diariamente, ou o texto que vocês estão lendo. Para elaborar uma forma de expressão uma língua recorta (do continuum dos sons que uma voz humana pode emitir), uma série de sons, excluindo outros, que existem e podem ser produzidos, mas não pertencem à língua em questão.

(...).

Para que os sons de uma língua sejam compreensíveis é preciso associar-lhes significados, ou seja, conteúdos. O continuum do conteúdo é o conjunto de tudo aquilo que se poderia pensar e dizer, isto é, o universo inteiro, físico e mental (na medida em que podemos falar a seu respeito). Porém, cada língua organiza o universo daquilo que pode ser dito e pensado em uma forma do conteúdo. Pertencem à forma do conteúdo (só para dar alguns exemplos) o sistema das cores, a organização do universo zoológico em gêneros, famílias e espécies, a oposição entre alto e baixo ou a oposição entre o amor e o ódio.

As várias maneiras de organizar o conteúdo mudam de uma língua para outra e, por vezes, conforme a maneira em que consideramos o uso comum de uma língua ou seu uso científico. (...). (2002, p. 40/41, itálicos no original).
\end{abstract}

Nessa passagem a língua é descrita como um código que não apenas associa sistemas de expressão e de conteúdo, mas que os cria para deles dispor associativamente. É a língua que concebe os sistemas cujos elementos irá associar; isto é, os sistemas da expressão e do conteúdo que serão associados pela língua não existem antes dela, nascem dela. E a descrição que Eco faz do ato de criação dos planos da expressão e do conteúdo demonstra toda a soberania da língua.

\footnotetext{
${ }^{31}$ A leitura deste trecho exige um cuidado específico. Para sua redação, logo no primeiro parágrafo, Eco assume valer-se da "noção teoricamente rigorosa de estrutura de uma língua natural", e essa noção é o modelo criado por Louis Hjelmslev. Hjelmslev não utilizou em seu modelo o conceito de "código" para referir-se à língua; define-a como um "sistema semiótico" (ver, para tanto, o capítulo n. 2, da parte II, desta dissertação). Não obstante, é possível ler esse trecho à luz dos conceitos do Tratado geral de semiótica e, para isso, basta substituir o termo "sistema" pelo termo "código" sempre que estiver se referindo ao termo "língua" e mantê-lo sempre que estiver se referindo aos planos da expressão e do conteúdo (sistemas, segundo o Tratado geral de semiótica).
} 
Para criar o plano da expressão, ela apodera-se "do continuum dos sons que uma voz humana pode emitir" e nele seleciona apenas os sons que considera pertinentes, descartando os demais. A língua de fato domina, determina e recorta toda uma esfera humana de possibilidades físico-sonoras. E ao recortar nessa esfera apenas o que considera pertinente para seu plano da expressão, como que desumaniza o que não foi recortado; afinal, apenas o que foi recortado poderá vir a ser associado a um elemento do plano do conteúdo e, com isso, tornar-se compreensível. Expressar-se fora das possibilidades recortadas pelo plano da expressão é não poder ser compreendido; é, portanto, sequer expressar (qualquer conteúdo).

Se a criação do plano da expressão já se mostrou como um acontecimento provocante e bastante elucidativo da soberania criativa, é com a criação do plano do conteúdo que a língua demonstra toda sua potência. Para criar o plano do conteúdo a língua apodera-se, segundo Eco, do universo inteiro! E o universo inteiro "é o conjunto de tudo aquilo que se poderia pensar e dizer, isto é, o universo inteiro, físico e mental (na medida em que podemos falar a seu respeito)". O universo inteiro, portanto, é o conjunto de tudo que existe, de algum modo, em algum lugar, no tempo. É o conjunto de tudo que, justamente por existir, poderia vir a constituir o conteúdo de um pensamento ou de uma fala. É desse conjunto que a língua se apodera para constituir seu plano do conteúdo. Esse apoderar-se pode ser imaginado como um encurralar sob si. À semelhança de uma ave de rapina que observa do alto sua presa e busca encurralá-la para criar o momento de atacá-la, a língua, também do alto, é capaz de observar o universo inteiro em sua totalidade. Nada do universo inteiro pode escapar à língua. Em sua posição de soberania, a língua posiciona-se suficientemente longe para conseguir observar a totalidade do universo inteiro, mas suficientemente perto para mantê-lo encurralado sob seu domínio. E, por dominálo de forma inevitável, organiza-o livremente para constituir seu plano do conteúdo. O plano do conteúdo, portanto, é o universo inteiro do que poderia ser pensado ou falado depois de organizado por uma língua. A língua transforma a possibilidade ilimitada de pensar e dizer (o que poderia ser pensado e dito) numa possibilidade determinada (o que pode ser pensado e dito). E cada língua realiza a seu modo essa organização.

Assim, se o compreendi minimamente bem, deve ter sido esse o punhado de motivos que conduziram Eco à seguinte afirmação: "Em função destas características uma língua natural pode ser vista como um sistema holístico: pois, enquanto estrutura, implica, de um certo modo, uma visão do mundo.” (2002, p. 42, itálicos no original). Essa marcante afirmação, não obstante breve, é suficiente para despertar algumas questões intrigantes. O que seria a visão do mundo? O que seria o mundo? E o que significa dizer que a língua implica uma visão do mundo? 
Cogitemos, em primeiro lugar, sobre o termo "visão". "Visão" é o substantivo que denomina um dos sentidos humanos, o sentido que nos permite enxergar o mundo e nele identificar, sem tocá-lo, suas formas, colorações e movimentos. Contudo, no contexto em que foi empregado ("uma visão do mundo"), o termo "visão" carrega consigo um significado que ultrapassa sua definição enquanto sentido humano. Nesse contexto, na verdade, "visão" tem como significado o resultado ou produto obtido por meio do exercício da visão. Por exemplo, dizer que se "possui uma visão de algo" é dizer que a visão já foi exercida e que, através desse exercício, conseguiu-se formar um juízo visual sobre determinado algo; é já ter visto algo de algum modo. O termo "visão", portanto, além de significar um dos cinco sentidos humanos, também significa a interpretação (ou juízo visual, ou compreensão visual, ou ponto de vista etc.) que foi permitida e produzida pelo ato de ver, pelo exercício da visão.

A partir desse segundo significado, podemos compreender a expressão "uma visão de mundo" como uma interpretação visual a respeito do mundo. Assim sendo, relembrando a citação feita há dois parágrafos, é possível compreender que a língua implica, de um certo modo, uma interpretação visual a respeito do mundo.

No entanto, é mesmo suficiente afirmar que a língua implica um modo de interpretar apenas visualmente o mundo? Essa afirmação esgota toda a potência da língua? Acredito que não. A língua parece poder implicar muito mais que um modo de ver o mundo. Por esse motivo, sugiro que a "visão" proposta por Eco seja compreendida como metonímia de sentido humano. Com isso, uma visão do mundo seria, na verdade, uma sensação de mundo. Repensando o verbo: "ver" o mundo seria "sentir" o mundo - não apenas vê-lo, mas também cheirá-lo e apalpá-lo e degustá-lo e ouvi-lo. E essa metonímia (a visão em lugar do gênero dos sentidos humanos, ou mesmo em lugar dos demais sentidos) não é incomum no cotidiano. Basta pensar em frases como "veja como é gostoso este vinho", "nunca que vi um pianista tocar tão bem”, "venha ver o perfume desta rosa", "recomendo que um dia veja presencialmente a atmosfera contagiante de um estádio de futebol”. Assim, a visão do mundo dita por Eco, parece-me que possa ser qualquer tipo de interpretação sensitiva do mundo. A língua implica uma complexa sensação do mundo - visual, gustativa, olfativa, tátil e auditiva. Para exemplificar, basta pensar na figura de linguagem denominada de sinestesia, ou nas categorias que descrevem os sabores de acordo com a região da língua que os percebe (azedo, salgado, doce...), ou nas categorias que classificam os aromas, ou naquelas que tentam explicar diferentes sensações táteis (liso, áspero, enrugado, afiado...). São alguns poucos exemplos, mas suficientes para demonstrar como a língua, de fato, mostra-se total ao implicar não apenas uma visão do mundo, mas todas as formas que coloca à disposição de seus falantes para que sintam o mundo, as únicas formas 
que realmente possuem. Contudo, ainda que assim seja, o que de fato seria esse "mundo" que é sentido a partir das estruturas de uma língua?

Pensando no que Eco havia dito antes de afirmar que a língua implica uma visão do mundo (grande parte do que citei na página n. 88 acima); é possível compreender o "mundo" como "o conjunto de tudo aquilo que se poderia pensar e dizer, isto é, o universo inteiro, físico e mental (na medida em que podemos falar a seu respeito)", ou seja, como o continuum do conteúdo. E se o "mundo" corresponde ao universo inteiro, a "visão do mundo", que é implicada pela língua, corresponde à organização que a língua impõe ao universo inteiro. Em outros termos: organizar o universo inteiro (mundo) a seu modo é organizá-lo de um modo; e organizá-lo de um modo é criar uma visão do mundo, a única forma de vê-lo (percebê-lo através dos sentidos e compreendê-lo) e sobre ele pensar e dizer (o plano do conteúdo).

Essa compreensão do termo "mundo" como sinônimo de "continuum do conteúdo" é reforçada pelo Tratado geral de semiótica ${ }^{32}$.

\begin{abstract}
Em segundo lugar, a vida dos campos semânticos parece demasiado breve em comparação com a dos sistemas fonológicos, cujas organizações não raro permanecem imutáveis através dos séculos em que se desenvolve a história completa de uma língua. Os campos semânticos dão forma às unidades de uma dada cultura e constituem, em suma, uma determinada organização (ou visão) do mundo; portanto, estão submetidos aos fenômenos de aculturação, de revisão crítica do conhecimento, de crises de valor e assim por diante.

Se quisermos aceitar, também para os sistemas semânticos, a metáfora saussuriana do xadrez, o movimento de uma peça modifica toda a fisionomia do jogo. Assim, basta que, no desenvolvimento de uma cultura, o termo |técnica| venha a veicular uma área de conteúdo diversa da usual para privar o termo |arte| de muitas das suas prerrogativas significantes. (2014, p. 66).
\end{abstract}

Nessa passagem, Eco afirma que os "campos semânticos" constituem uma determinada organização ou visão do mundo. Os "campos semânticos" são conjuntos sistemáticos de unidades culturais; e as unidades culturais são os elementos que compõem o plano do conteúdo de qualquer código; são, como diz Eco, “(...) sistemas de unidades culturais altamente organizadas, como o campo das cores ou os termos de parentesco" (2014, p. 65). Em

\footnotetext{
${ }^{32}$ É imprescindível lembrar que, nessa obra, a intenção de Eco é analisar e explicar todo e qualquer código que permita a ocorrência de uma função sígnica. Com isso, muitas vezes é um tanto difícil distinguir quando Eco está falando sobre a língua e quando está falando sobre um outro tipo de código, também genérico e abrangente, como a cultura. Por outro lado, há passagens, como a que será citada a seguir, nas quais ele inicia falando sobre a língua e, de repente, deixa de falar expressamente, criando a dificuldade de se saber se continua dela falando, ainda que de forma pressuposta, ou se passou a falar dos códigos em geral. Mas como, e isso é certo, está empenhado em constituir uma teoria explicativa de todos os códigos existentes, tudo o que diz pode ser aplicado à língua que, como demonstrado, é também um código.
} 
suma, os campos semânticos representam as estruturas que definem a organização do plano do conteúdo ${ }^{33}$.

O plano do conteúdo, então, é formado por unidades culturais que são as unidades representativas de tudo que pode ser dito e pensado. Cada língua cria suas unidades culturais e delineia seus campos semânticos para organizar tais unidades culturais. Cada língua, destarte, cria seu mundo e organiza-o a seu modo, impondo uma visão a seu respeito, uma visão do mundo. Mas essa visão do mundo não é perene. Segundo Eco, ela se mostra suscetível de alteração por "fenômenos de aculturação, de revisão crítica do conhecimento, de crises de valor e assim por diante". Esses acontecimentos descritos como capazes de promover alterações na organização (reorganização) do plano do conteúdo, se interpretados em termos semióticos, são denominados de juízos fatuais.

Um sistema semântico constitui um modo de dar forma ao mundo. Como tal, constitui uma interpretação parcial do próprio mundo (como continuum do conteúdo) e pode ser sempre reestruturado apenas novos juízos fatuais intervenham para pô-lo em crise. (2014, p. 245, itálicos no original).

Essa passagem é interessante não apenas por introduzir o tema da possibilidade de reestruturação do plano do conteúdo, mas também para evidenciar que o termo "mundo" é tido, por Eco, como sinônimo de continuum do conteúdo. Mas vejamos então o que são esses juízos e o que é a crise de organização que provocam.

$\mathrm{O}$ fato de que a semiose vive como fato num mundo de fatos limita a pureza absoluta do universo dos códigos. A semiose ocorre entre eventos, e dão-se eventos que nenhum código previa. A criatividade semiótica permitida pelos códigos requer então que esses eventos sejam nomeados e descritos. A organização dos códigos pode mesmo ser posta em crise por assertos inovadores que se referem a eventos não previstos pela organização do sistema do conteúdo. Que acontece, então, quando uma mensagem se refere a algo que o sistema do conteúdo não havia ainda segmentado e organizado? O novo conjunto de unidades culturais assim introduzido na competência social modifica os campos semânticos preestabelecidos? E como?

(...).

Chamemos SEMIÓTICO a um juízo que predica de um dado conteúdo (uma ou mais unidades culturais) as marcas semânticas já atribuídas a ele por um código

\footnotetext{
${ }^{33} \mathrm{O}$ que convém destacar é: sempre que Eco versar sobre semântica, estará falando sobre o plano do conteúdo de um código, e não sobre o plano da expressão. A seguinte passagem servirá para ilustrar essa afirmação: "Naturalmente, a semântica estrutural tende a estabelecer uma sorte de desenho do Espaço Semântico Global (ou da Forma do Conteúdo no sentido hjelmsleviano)." (2014, p. 66).
} 
preestabelecido; e chamemos FATUAL a um juízo que predica de um dado conteúdo marcas semânticas não atribuídas a ele antes pelo código.

Assim, |todo homem não casado é solteiro| constitui um juízo semiótico na medida em que existe um código que assigna a solteiro a marca não-casado. Ao contrário, |Luís é solteiro| constitui um juízo fatual. No dia 28 de outubro de 1922, |Mussolini tomou o poder na Itália| constituía um juízo fatual. Mas a partir daquele momento o mesmo enunciado começou a representar um juízo semiótico, porque a sociedade institucionalizou aquele dado de conhecimento, e numa representação enciclopédica de $<<$ Benito Mussolini $>>$ deve-se encontrar a característica de ter-se apoderado do poder no dia 28 de outubro de 1922. Ao contrário, admitindo-se que tenha sido pronunciado, o enunciado |no dia 28 de outubro Mussolini bebeu uma xícara de café| foi ou poderia ser um juízo fatual com escassas probabilidades de transformar-se num juízo semiótico. (2014, p. 137/138, itálicos no original).

No primeiro e no segundo parágrafos citados, referindo-se a qualquer código possível, Eco expõe a noção de crise no plano do conteúdo e a define como uma desobediência à sua organização cometida por um juízo com potencial inovador (“asserto inovador”). O juízo inovador atribui a um conteúdo (uma ou mais unidades culturais) marcas semânticas que ainda não haviam sido previstas pela organização do plano do conteúdo e, ao fazê-lo, provoca a crise. Como já havia sido adiantado, esses juízos inovadores são denominados por Eco de juízos fatuais. Os juízos fatuais são definidos em oposição aos intitulados juízos semióticos; estes não provocam qualquer crise, pois sempre respeitam a organização anterior do plano do conteúdo para se referir a qualquer unidade ou conjunto de unidades culturais.

No terceiro parágrafo, Eco passa a dar exemplos de juízos fatuais e semióticos. Para tanto, baseia-se num código específico, que poderia ser identificado como um tipo de enciclopédia cultural vigente numa sociedade (provavelmente a italiana). De todo modo, não parece se referir a uma língua. Mas o que importa notar no terceiro parágrafo é: nem todos os juízos fatuais que provocam uma crise na organização do plano do conteúdo motivam a posterior reorganização. Eco afirma que a reorganização só acontecerá quando e se o juízo semiótico for institucionalizado; isto é, apenas quando a sociedade que se comunica com base no código posto em crise passar a repetir aquele juízo fatual, aceitando-o assim como um novo conteúdo e incluindo-o na organização do plano do conteúdo. Essa institucionalização marca não apenas a reorganização do plano do conteúdo, mas também a transformação do juízo fatual em juízo semiótico.

E se os juízos fatuais trazem algo de fora ("num mundo de fatos") para reorganizar o plano do conteúdo por dentro (sua organização interna); Eco apresenta ainda as mensagens retóricas (ou o jogo retórico) que, por sua vez, partem de dentro do plano do conteúdo para reorganizá-lo (por dentro). Vejamos uma passagem um tanto extensa, porém extremamente 
explicativa acerca desse jogo retórico, que é um jogo jogado com a organização interna do plano do conteúdo.

\begin{abstract}
O jogo retórico, traçando conexões imprevisíveis (ou escassamente previstas e desfrutadas), revela férteis contradições. Como ele ocorreu entre os ramos do semema, e como cada nó desses ramos é por sua vez origem de um novo semema (como mostrou o modelo Q), a substituição retórica estabelece novas conexões e permite percorrer toda a área do Campo Semântico Global, pondo a nu sua estrutura 'topológica'. Nessa atividade, as seleções contextuais e circunstanciais são frequentemente sobrepostas, comutam-se uma com a outra, curtos-circuitos de todo tipo criam contatos imprevistos. Quando o processo se verifica com rapidez e conecta pontos distantes entre si, tem-se a impressão a impressão psicológica de um 'salto' e o destinatário, embora lhe advirta confusamente a legitimidade, não consegue individuar com clareza todos os passos que, no interior das cadeias sêmicas, unem os pontos aparentemente desconexos. Como resultado, o destinatário acredita que a invenção retórica seja o efeito de uma intuição 'fulgurante' e inexplicável, uma revelação, uma iluminação (a 'Linguagem habitada pela Verdade Poética'), ao passo que, na realidade, o emitente simplesmente percebeu com extrema rapidez o circuito das concatenações que a organização semântica lhe permite percorrer. Aquilo que para o emitente se colocou como uma Visão de conjunto das possibilidades do sistema, para o destinatário torna-se algo de vago e indistinto, de modo que o segundo atribui ao primeiro uma capacidade intuitiva superior, o que de resto é verdadeiro se se define como |intuição| uma visão rápida e articulada da estrutura subjacente do campo semântico (e provavelmente uma capacidade de fazer funcionar em nivel cortical as próprias capacidades de conexão entre 'pontos' do sistema com uma velocidade superior à média). Mas, se o destinatário consegue dar-se conta do percurso feito, ambos realizaram uma nova maneira de interconectar unidades semânticas e o processo retórico (que em certos casos se assimila ao estético) tornase uma forma autorizada de conhecimento, ou pelo menos um modo de pôr em crise o conhecimento adquirido. (2014, p. 241, itálicos no original).
\end{abstract}

O jogo retórico é o brincar com as possibilidades encobertas de organização do plano do conteúdo. Aquele que busca emitir uma mensagem retórica põe sobre a mesa todas as possibilidades de combinação de unidades culturais e campos semânticos que lhe são dadas pelo plano do conteúdo; visualiza as mais comuns, que saltam com maior evidência, mas busca as mais ocultas. É com as combinações mais ocultas que o jogo pode começar. A mensagem retórica é, portanto, jogada no tabuleiro das combinações menos evidentes, e por isso mais surpreendentes, é onde as peças desveladas são lançadas e inter-relacionadas. Com a mensagem retórica, o emitente tentará produzir os efeitos que deseja no destinatário, convidando-o para o jogo.

O que considero mais interessante sobre o jogo retórico é o fato de ser permitido pelo próprio plano do conteúdo. O jogo retórico não cria algo de fato novo (como os juízos fatuais), apenas coloca em evidência conexões já existentes, mas não tão evidentes. Quero dizer, se produz uma revisão do conhecimento, ou se coloca em crise um conhecimento adquirido, é 
porque desvenda outros (e não "novos") pontos de vista sobre o que já se conhecia, pontos de vista antes ignorados. Encontra dentro do plano que determina a visão do mundo uma visão subutilizada, mas, ainda assim, uma visão do mundo. O retórico, portanto, não é alguém que cria "novos" pontos de vista, é alguém que, com muita habilidade, encontra pontos de vista não utilizados dentro dos pontos de vista possíveis, ao lado dos anteriormente utilizados. Logo, a reorganização promovida pelo jogo retórico não é uma inclusão de novas unidades culturais, como promove o juízo fatual, mas a tonificação de conexões antes átonas.

Porém, se se diferem quanto a reorganização que promovem no plano do conteúdo, tanto os juízos fatuais quanto o jogo retórico identificam-se por dispensarem qualquer alteração no plano da expressão para alcançar a alteração no plano do conteúdo. Tanto os juízos fatuais quanto o jogo retórico valem-se do plano de expressão instituído pelo código - respeitam-no, portanto - para reorganizar o plano do conteúdo. Desse modo, ambos se distinguem de uma outra forma de reorganização do plano do conteúdo apresentada por Eco, que promove um desvio também no plano da expressão. Essa forma é denominada de texto estético, ou uso estético da linguagem.

O uso estético da linguagem merece atenção por várias razões: (i) um texto estético implica um trabalho particular, qual seja, uma manipulação da expressão (cf. 3.7.2); (ii) essa manipulação provoca (e é provocada por) um reajustamento do conteúdo (3.7.3); (iii) esta dupla operação, produzindo um gênero de função sígnica altamente idiossincrática e original (3.7.4), vem refletir-se, de certa forma, nos códigos que servem de base à operação estética, provocando um processo de mutação de código (cf. 3.7.5); (iv) a operação completa, mesmo quando visa à natureza dos códigos, produz com frequência um novo tipo de visão do mundo (cf. 3.7.6); (v) enquanto visa a estimular um complexo trabalho interpretativo no destinatário, o emitente de um texto estético focaliza sua atenção nas possíveis relações, de modo que tal texto representa um retículo de atos locutativos, ou comunicativos, que objetivam solicitar respostas originais (cf. 3.7.7). (2014, p. 222, itálicos no original).

O nome texto estético não é, como se percebe, um acaso. $\mathrm{O}$ emissor do texto estético empenha-se em provocar um desvio no funcionamento normal do plano da expressão para criar um efeito estético que atue como um atrativo para a percepção, sobretudo visual, do destinatário. O efeito estético é o chamamento da atenção do destinatário, é a provocação à indagação não apenas do plano do conteúdo, mas também do plano da expressão. Como consequência, a atenção do destinatário é primeiro atraída pelo plano da expressão para, a partir da identificação do desvio, então ser remetida à alteração provocada também no plano do conteúdo. Ou seja, o texto estético reorganiza o plano do conteúdo e busca expor essa alteração 
criando um desvio no plano da expressão. O texto estético confessa-se como desviante. E, por promover uma alteração no plano do conteúdo, promove uma alteração na visão do mundo instituída pela língua, como bem ressalta Eco:

\begin{abstract}
Nesse processo o texto estético, mais que suscitar apenas 'intuições', proporciona um INCREMENTO DE CONHECIMENTO CONCEPTUAL.

Ao obrigar a reconsiderar os códigos e suas possibilidades, ele impõe uma reconsideração da linguagem inteira em que se baseia. Mantém a semiose 'em alheamento'. Assim fazendo, desafia a organização do conteúdo existente e, portanto, contribui para mudar o modo pelo qual uma cultura 'vê' o mundo.

Por conseguinte, é precisamente o tipo de texto de que tantas vezes se falou que exige a "suspensão da incredulidade", que estimula a suspeita de que a organização do mundo a que estamos habituados não é definitiva.

O que não equivale a dizer que a obra de arte 'diga a Verdade'. O que ela faz é simplesmente pôr em questão as verdades adquiridas, convidando a uma nova análise dos conteúdos.

Se, pois, os textos estéticos podem mudar nossa visão do mundo, não será de pouco interesse tê-los presentes naquele ramo da teoria da produção sígnica que estuda a adequação entre proposições e estados do mundo. (2014, p. 232).
\end{abstract}

É curioso notar uma peculiaridade do texto estético nessa promoção da reorganização do plano do conteúdo e consequente modificação da visão do mundo vigente. O texto estético, por desafiar também o plano da expressão, não modifica apenas a visão do mundo, mas também o modo de se expressar sobre o mundo. Os juízos fatuais e o jogo retórico, por exemplo, apesar de capazes de alterar a visão do mundo, fazem-no sem tocar na forma como a visão do mundo alterada continuará a ser expressada - continuará a ser expressada por uma unidade (ou conjunto de unidades) já existente no plano da expressão.

Esse potencial de reorganização dos dois planos de qualquer código, expressão e conteúdo, faz com que o texto estético provoque uma alteração no próprio código, isto é, provoque uma mutação de código. Pois bem, como algo capaz de motivar uma mutação de código e, portanto, uma instituição de um novo código, o texto estético foi classificado por Eco como invenção - uma das categorias de produção sígnica por ele expostas ${ }^{34}$.

Definimos como INVENÇÃO um modo de produção em que o produtor da função sígnica escolhe um novo continuum material ainda não segmentado para os fins que se propõe, e sugere uma nova maneira de dar-lhes forma para TRANSFORMAR nele os elementos pertinentes de um tipo de conteúdo. (2014, p. 208, itálicos no original).

\footnotetext{
${ }^{34}$ Categorias de produção sígnica, ver p. 190/220; categoria da invenção, ver p. 208/217; e texto estético como invenção, ver p. 222/234 (2014).
} 
Como se percebe, o conceito de texto estético definido como uma mensagem que promove um desvio no plano da expressão para provocar uma reorganização do plano do conteúdo é, de fato, encaixável na definição de invenção.

Eco distingue no Tratado geral de semiótica algumas formas de invenção ${ }^{35}$, as quais não serão aqui aprofundadas, pois sua análise não se mostra indispensável para que possamos alcançar a conclusão que expõe acerca da invenção enquanto categoria - conclusão que é bastante para os fins desta dissertação. Vejamo-la.

\begin{abstract}
Quanto dissemos até agora induz-nos, ao contrário, a crer que nunca ocorrem casos de invenção radical pura, e provavelmente sequer de invenção moderada pura, dado que (como já se aludiu), para que a convenção possa nascer, é necessário que a invenção do ainda não dito seja envolvida pelo já dito. E os textos 'inventivos' são estruturas labirínticas em que as invenções se enastram com réplicas, estilizações, ostensões e assim por diante. A semiose nunca surge ex novo e ex nihilo.

$\mathrm{O}$ que equivale a dizer que qualquer nova proposta cultural sempre se delineia contra o fundo de cultura já organizada.

Dissemo-lo em 2.1 e 2.4: não existem signos como tais, e muitos dos assim chamados signos são na verdade textos; e signo e texto resultam de correlações em que colaboram vários modos de produção. Se a invenção fosse uma categoria da tipologia dos signos, então talvez fosse possível individuar signos que são invenções absolutas e radicais, os quais constituiriam o exemplo tangível daqueles momentos "aurorais" de nascimento da linguagem que representam a grande descoberta e a via sem saída da linguística idealista. Mas se, ao invés, a invenção é, como se propôs, um dentre os numerosos modos de produção sígnica, colaborando com outros para a formulação de funtivos e para a sua correlação, então a falácia idealista se vê exorcizada.

Os homens instituem e reorganizam continuamente os códigos unicamente porque existem códigos precedentes. No universo semiótico não existem nem heróis nem profetas. Mesmo os profetas, para se tornarem verdadeiros, devem ser socialmente aceitos: do contrário, serão falsos profetas. (2014, p. 216/217, itálicos no original).
\end{abstract}

Essa conclusão é, talvez, um tanto desalentadora. O que Eco nos diz sem embromar é, basicamente: uma vez dentro do código, sempre dentro do código. E mais, diz que sempre se esteve no código, pois nenhuma produção sígnica, nenhuma semiose, portanto, surge como algo completamente novo, pois nada pode surgir do nada. Logo, mesmo a invenção, enquanto modalidade de produção sígnica capaz de abalar um código existente, sempre parte de um código para chegar a um código. O novo nunca é novo, pois enquanto é novo, ainda não é, e

\footnotetext{
${ }^{35}$ Ver nota anterior para encontrar os tipos de invenção no Tratado geral de semiótica.
} 
quando passa a ser, deixa de ser novo. Todo código defende-se de invenções ao possibilitar sua recodificação. E se algo é codificado, já deixou de ser contra o codificado.

E essa imunidade à invenção, é claro, também caracteriza a língua enquanto código. Assim como em qualquer sistema semiótico, na língua também não há revoluções. Há, quando muito, reorganizações que são sempre permitidas pela própria língua, pois partem dela para chegar a ela. Tais reorganizações são logo absorvidas como se sempre houvessem sido língua, ou ocorrem tão gradualmente que sequer são notadas como reorganização.

Tomemos então uma língua como um sistema de regras: não apenas as gramaticais, mas também as hoje assim chamadas pragmáticas; por exemplo, a regra de conversação que à pergunta se responde de modo pertinente, e quem a viola é julgado, a cada vez, mal-educado, bobo, provocador, ou se crê que esteja aludindo a alguma outra coisa que não quer dizer. A literatura, que trapaceia com a língua, apresenta-se como atividade que desagrega as regras e propõe outras: provisórias, válidas no âmbito de um discurso único e de uma só corrente; e sobretudo válidas no âmbito do laboratório literário. Isso significa que Ionesco trapaceia com a língua fazendo suas personagens falarem como falam, por exemplo, na Cantora careca. Mas se no relacionamento social todos falassem como a cantora careca, a sociedade se desagregaria. Note-se que não se teria revolução linguística, porque a revolução implica a reviravolta das relações de poder; um universo que fala como Ionesco não derrubaria nada, instauraria uma espécie de grau $n$ (oposta a zero, um número indefinido) do comportamento. Nem seria mais possível sequer comprar pão do padeiro.

Como a língua se defende desse risco? Barthes o diz, reconstituindo uma situação de poder diante da própria violação, absorvendo-a (o anacoluto do artista torna-se norma comum). Quanto à sociedade, essa defende a língua recitando a literatura, que põe em questão a língua, em lugares determinados. Assim dá-se que na língua nunca se tem revolução: ou é revolução simulada, sobre um palco, onde tudo é permitido, depois volta-se para casa falando do jeito normal; ou é movimento infinitesimal de reforma contínua. $\mathrm{O}$ estetismo consiste em acreditar que a arte seja a vida e a vida arte, confundindo as zonas. Iludindo-se. (1984, p. 328/329, itálicos no original).

Na língua não há revoluções. A língua não admite revoluções. Se admite alterar-se pontualmente, fá-lo para manter-se; e, mantendo-se, mantém a visão do mundo que tem o poder de implicar. E se, além de pensar nessa imunidade à revolução, também lembrarmos que a "visão do mundo" implicada corresponde à organização que a língua impõe ao universo inteiro (que é seu continuum do conteúdo) para constituir o plano do conteúdo; podemos começar a enxergar como o ser da língua mostra-se em si mesmo.

Vale lembrar, o continuum do conteúdo que Eco especificamente vincula à língua é “o conjunto de tudo aquilo que se poderia pensar e dizer, isto é, o universo inteiro, físico e mental (na medida em que podemos falar a seu respeito)". O "mundo" que é organizado pela língua corresponde ao continuum do conteúdo, que corresponde ao universo inteiro do que poderia ser 
dito ou pensado; e a organização corresponde à "visão" que é implicada pela língua, a visão do mundo.

Ao impor uma organização ao universo inteiro (mundo), a língua, inevitavelmente, exclui outras possibilidades de organização. Foi por esse motivo que acima se afirmou que a língua, ao implicar uma visão do mundo, implica a única visão do mundo. E ao implicar uma única possível visão do mundo (todos os possíveis modos de interagir com esse mundo), a língua acaba por mostrar-se como o mundo (organizado). Afinal, quando se está na língua (quando se está subjugado por esse código), só se pode pensar e dizer o que já é língua enquanto mundo organizado (plano do conteúdo); e, por outro lado, só se pode pensar e dizer - expressarse para si e para outrem - através dos mecanismos disponibilizados pela própria língua (plano da expressão).

A língua, portanto, mostra-se em seu modo de ser como o mundo. Ou seja, o ser da língua mostra-se em si mesmo como ser-o-mundo. E o ser-o-mundo como interpretação fenomenológica da língua é possibilitado ainda por sua capacidade de excluir revoluções. Por ser imune a qualquer revolução, a língua mantém-se como o mundo ao manter a implicação de uma visão do mundo. Isto é, sendo, a língua continua sendo o mundo, pois também a visão do mundo que implica continua sendo. O ser-o-mundo mostra-se então, de fato, como um modo de ser, como o modo de ser da língua. Por outro lado, convém ainda destacar a primazia fenomenológica que esse modo de ser parecer conferir à língua. Se, sendo, a língua mostra-se em seu modo de ser como o mundo, ser e estar no mundo é, consequentemente, ser e estar na língua. Como mundo, a língua mostra-se também como o onde o ser está, como o onde se pode ser.

Enfim, exposta a interpretação fenomenológica sobre a língua que encontrei em Eco, cabe agora passar ao tópico dedicado ao signo linguístico. Para introduzir essa passagem, vale relembrar a citação feita há duas páginas, na qual Eco, ao expor sua conclusão sobre a “invenção", afirmou que "não existem signos como tais". Passemos então para o próximo tópico para compreender o tratamento que Eco confere ao signo e o porquê de afirmar sua inexistência.

\section{c) E o signo linguístico}

É preciso dizer, desde já, que Eco não chegou a tratar especificamente do signo linguístico em nenhuma das obras listadas na bibliografia. Quando fala sobre signo, deles fala como categoria semiótica, fala sobre quaisquer signos. Diz o que pensa ser aplicável a qualquer 
signo, seja lá o que forem os signos, seja lá o que fossem os signos, que considera inexistentes. Eco não demonstra qualquer afeição a esse conceito constituído pela tradição linguística; pelo contrário, confessa sua opinião pela quase inutilidade desse conceito. Inutilidade que só não é atingida porque, como qualquer outro lugar-comum, confere alguma clareza para a exposição que o invoca. Acredito, pois, que seja esse o motivo por que Eco, mesmo depois de declarar a inexistência do signo, continua a empregá-lo. Mas a continuidade do emprego não é uma atitude ingênua, mas estratégica. Eco vale-se do lugar-comum, sim, porém indica de forma clara como deve ser compreendido: como o todo formado por uma função sígnica.

Essa definição que se vale do conceito de função sígnica foi apresentada e explicada já no tópico anterior, dedicado à língua ${ }^{36}$. Entretanto, os problemas decorrentes dessa definição ainda não foram comentados. Vejamo-los.

A função sígnica é a correlação de dois funtivos. Um desses dois funtivos é constituído por um ou mais elementos de um plano da expressão; o outro é constituído por um ou mais elementos de um plano do conteúdo. Há, portanto, um número mínimo de elementos para que possa existir um funtivo (cada funtivo deve ser o conjunto de, pelo menos, um elemento), mas não há um número máximo. Ou seja, em princípio, cada funtivo pode apresentar qualquer “extensão". Desse modo, se o signo equivale ao todo representado por uma função sígnica, pode-se dizer que não possui uma “extensão" fixa.

Tais presunções implicam algumas consequências: (a) UM SIGNO NÃO É UMA ENTIDADE FÍSICA, porquanto a entidade física é, no máximo, a ocorrência concreta do elemento pertinente da expressão; (b) UM SIGNO NÃO É UMA ENTIDADE SEMIÓTICA FIXA, mas antes o local de encontro de elementos mutuamente independentes, oriundos de dois sistemas diferentes e associados por uma correlação codificante. Propriamente falando, não há signos, mas funções sígnicas (Hjelmslev, 1943).

Uma função sígnica se realiza quando dois funtivos (expressão e conteúdo) entram em mútua correlação: mas o mesmo funtivo pode também entrar em correlação com outros elementos, tornando-se assim um funtivo diferente, que dá origem a uma outra função sígnica.

Assim, os signos são o resultado provisório de regras de codificação que estabelecem correlações transitórias em que cada elemento é, por assim dizer, autorizado a associar-se com um outro elemento e a formar um signo somente em certas circunstâncias previstas pelo código. (2014, p. 39/40).

Essa incerteza acerca dos contornos do signo impede que seja definido como uma unidade já reconhecida. Esse impedimento pode ser exemplificado. Um signo pode ser, mas

\footnotetext{
${ }^{36}$ Ver p. 87 desta dissertação.
} 
não é só, uma palavra, um texto, uma imagem, um filme, uma estátua, um pensamento... pode ser tudo que puder ser explicado como uma função sígnica (como algo constituído pela correlação entre uma expressão e um conteúdo). Mas, por poder ser praticamente tudo, acaba por não ser nada. Se tudo é signo, nada é signo. E se o signo não é nada em si, não existe. Esse é, imagino, o percurso que Eco percorre até chegar à conclusão de que não existem signos. Ao tentar responder à pergunta "o que é o signo?", não encontra resposta, não encontra nada.

Quando se tenta definir o signo, acaba-se por defini-lo através de um conceito de

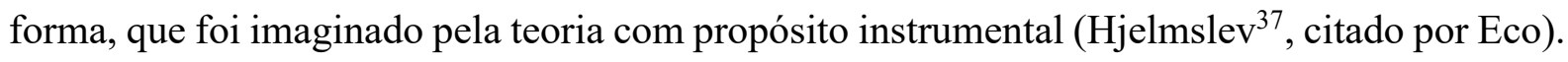
A função é uma forma que se pode projetar sobre um objeto de estudo para tentar compreendêlo e explicá-lo; não é uma característica ontológica, mas um ponto de vista. Por outro lado, a função, enquanto conceito, já possui uma definição formal e suficiente. A função é suficientemente definível por seus funtivos (é a relação entre funtivos) e estes são suficientemente definidos pela função que constituem (funtivos são os elementos em função).

Eis a situação paradoxal do conceito de signo. Indefinível em si, não há. O que há é a função sígnica, algo que lhe é externo, mas que serve para defini-lo e explicá-lo de algum modo. Assim, se para o desenvolvimento da teoria era necessário que existisse uma resposta para a questão sobre o que é o signo, então ele deve ser compreendido como uma forma, como uma função denominada de sígnica, que é a correlação entre elementos de um plano de expressão e elementos de um plano do conteúdo.

Vê-se, portanto, como a questão sobre o que é o signo mostra-se frustrante: o signo não é nada em si mesmo. Eco propõe, então, que a compreensão do signo seja tentada através da questão: “como é o signo?”. Um questionamento de caráter fenomenológico, como admite.

\begin{abstract}
Compreende-se então que existem signos que parecem mais adaptados para exprimir correlações abstratas (como os SíMBOLOS) e outros que parecem ter uma relação mais direta com os estados do mundo, como os ÍNDICES e os ÍCONES, mais diretamente envolvidos nos atos de menção de objetos. Como os chamados 'tipos de signos' parecem estar, por definição, ligados ao seu uso mais ou menos referencial, afigura-se mais oportuno fazer preceder a indagação sobre a tipologia dos signos pela indagação sobre os processos de referência.

Portanto, os parágrafos seguintes não seguem a ordem dos argumentos delineada na Fig. 31, e procedem segundo prioridades que definiremos mais 'fenomenológicas'.

Falar das menções serve para indicar vários tipos de signos postos em jogo (do dedo apontado aos objetos ostentados como representantes de uma classe); e, uma vez identificadas diferenças e similaridades nos vários modos de produzir estes signos, descobre-se também que essas diferenças não caracterizam os chamados 'signos' em si mesmos, mas o modo como são produzidos, ou antes, uma série de modalidades
\end{abstract}

${ }^{37}$ Para algumas noções sobre a taxonomia de formas criada por Hjelmslev, ver capítulo n. 2, da parte II desta dissertação. 
produtivas que não determinam diretamente tipos de signos, de maneira que os tipos de signos aparecem antes como o resultado de diversas modalidades operativas. Assim, uma tipologia dos signos deverá ceder lugar a uma tipologia dos modos de produção sígnica, mostrando uma vez mais a vacuidade da noção clássica de 'signo', simulação da linguagem cotidiana cujo posto teórico é ocupado pela noção de função sígnica como resultado de diversos tipos de operação produtiva. (2014, p. 136/137, itálicos no original).

Como se percebe, a pergunta pelo como do signo revela uma qualidade: a instrumentalidade. O signo é qualificado por uma instrumentalidade, é algo que é usado para algo, para uma finalidade. Quem utiliza o signo almeja, em maior ou menor medida, fazer referência a algo, seja a uma correlação abstrata (símbolos), seja a um estado do mundo (índices e ícones). Por essa instrumentalidade, Eco afirma que para imaginar uma forma de classificar os signos (tipologia), é mais conveniente questionar os "processos de referência", isto é, os diferentes modos de fazer referência através do uso dos signos. Assim, perguntar sobre o como dos signos é, portanto, perguntar sobre o modo como o signo é utilizável por aqueles que o utilizam.

Mas o fazer referência através do uso dos signos possui uma peculiaridade: para se usar um signo deve-se produzi-lo, pois só se pode usar o signo que se produz... para ser usado. Para melhor compreender a relação de pressuposição entre produção e uso, basta lembrar do que foi dito no tópico sobre a língua, quando foi feita a passagem do conceito de função sígnica para o conceito de código ${ }^{38}$. Relembrando rapidamente o raciocínio: um signo corresponde ao todo formado por uma função sígnica; a função sígnica é a correlação entre elemento(s) de um plano do conteúdo e elemento(s) de um plano da expressão; e as possibilidades de correlação entre elementos de diferentes planos (sistemas) são previstas e permitidas por um código. $\mathrm{Ou}$ seja, se há função sígnica (se há signo), há um código que prevê a possibilidade de produção dessa função sígnica. E quem usa um signo, fá-lo somente porque conhece um código que o instrui sobre como produzir e como usar esse signo. Portanto, para fazer referência ao que quer que seja, é necessário utilizar-se de um signo, e, para utilizar-se de um signo, deve-se criá-lo.

Diante disso, Eco afirma que no lugar de uma tipologia dos signos deverá entrar uma tipologia dos modos de produção dos signos (dos processos de referência). Afinal, se os signos não são nada em si, não se diferenciam por si; diferenciam-se, na verdade, por conta dos

\footnotetext{
${ }^{38}$ Ver p. 87 desta dissertação.
} 
diferentes modos como são produzidos e, assim, usados. São as diferenças entre os modos de produção dos signos que serão postos em tipologia, não os signos em si $^{39}$.

Em síntese, é possível concluir que o signo, enquanto categoria semiótica, sofre de vacuidade: quando questionado sobre o que é, não se mostra, não é nada em si e não pode ser definido em si. Entretanto, quando investigado em seu modo de ser, mostra-se como instrumento para aqueles que o empregam com o intuito de fazer referência a algo. O signo instrumentaliza e, assim, viabiliza o processo de referência.

A partir de agora, e finalmente, tendo em vista as conclusões resumidas no parágrafo anterior, é possível analisar especificamente o signo linguístico. Creio que o fato de Eco não ter tratado especificamente do signo linguístico não deva constituir um óbice a essa tentativa. Se sua intenção foi formular uma teoria explicativa de qualquer signo, do signo enquanto categoria semiótica, é inevitável que seja aplicável a um imaginável signo linguístico, pertencente ao código "língua".

E se o signo linguístico é um signo, sofre igualmente de vacuidade. O signo linguístico não é nada em si mesmo e, por esse motivo, não pode ser definido por si mesmo. Se se tentasse defini-lo, chegar-se-ia igualmente à função sígnica, pois o signo linguístico também não se mostraria como nada além de uma correlação entre expressão e conteúdo. Ou seja, é possível reformular a frase de Eco acima citada: não há signos linguísticos, mas funções sígnicas (uma função sígnica-linguística, pode-se denominar).

Vê-se que a pergunta sobre o que é o signo linguístico mostra-se frustrante tal qual a pergunta pelo que é o signo: ambas não revelam nada. E essa frustração é o impulso para que passemos à pergunta seguinte e questionemos o signo linguístico em seu modo de ser. Como é o signo linguístico? A resposta a essa questão representa a interpretação fenomenológica sobre o signo linguístico que encontrei em Eco.

A resposta, um tanto previsível, é: o modo de ser do signo linguístico é também marcado pela instrumentalidade. Em outros termos, o ser do signo linguístico mostra-se em si mesmo como instrumentalidade, como ser-para, como algo que pode ser usado para algo. E se os signos instrumentalizam os processos de referência em geral, o signo linguístico instrumentaliza os processos de referência que são realizados com base no código da língua. São os falantes da língua que usam o signo linguístico para fazer referência a algo, seja a

\footnotetext{
${ }^{39}$ É esse o fundamento da Teoria da produção sígnica, uma tipologia das operações produtivas. Há de se ressaltar, contudo, que os diversos tipos de operações produtivas não serão aqui tratados, pois não são indispensáveis para alcançar a conclusão que será exposta a seguir. Para conhecer a tipologia, ver p. 190/220 do Tratado geral de semiótica (2014).
} 
correlações abstratas, seja a estados do mundo. Assim, o signo linguístico, sendo, mostra-se em seu modo de ser como o instrumento usado pelos falantes da língua no processo de referência (ser-para-o-falante). 


\title{
Capítulo 5. Izidoro Blikstein.
}

\begin{abstract}
A nossa cognição estaria sujeita, portanto, a um processo ininterrupto de estereotipação, a ponto de considerarmos real e natural todo um universo de referentes e realidades fabricadas. Daí a função fascista da linguagem, segundo a expressão de R. Barthes. A língua "amarra" a percepção/cognição, impedindo o indivíduo de ver a realidade de um modo ainda não-programado pelos corredores de estereotipação; como Sísifo, estaríamos condenados a conhecer, ou a reconhecer, sempre a mesma realidade: nossas retinas "fatigadas" estariam condenadas a ver sempre a mesma "pedra-no-meio-do-caminho" de Carlos Drummond de Andrade. (1985, p. 82, itálicos no original).
\end{abstract}

\section{a) Preliminarmente}

Este capítulo, o último capítulo dentre os dedicados à apresentação das interpretações fenomenológicas da língua e do signo linguístico encontradas em obras de linguistas selecionados, não poderia referir-se a outrem que não fosse Izidoro Blikstein. Blikstein leu, muito antes de mim, todos os linguistas que o antecederam nos capítulos anteriores. Leu também muitos outros - e demonstra-o com sutileza e precisão inigualáveis nas pouquíssimas, mas profundíssimas páginas de seu Kaspar Hauser. Sua erudição é inspiradora. Sua bibliografia é inspiradora: inigualável tradutor dos maiores clássicos da linguística que chegaram, em sua época, a nossa terra. Foi esse currículo que lhe permitiu criticar a postura adotada pela linguística até então, uma linguística que abominava o referente e, com isso, não havia sido capaz de explicar suficiente e satisfatoriamente a significação.

Blikstein foi o último autor selecionado para compor a presente dissertação. Quando Roland Barthes pareceu escapar ao tema, decidi procurar outros autores para suprir a lacuna. Minha busca foi por brasileiros. Blikstein foi o primeiro encontrado, imediatamente notado como tradutor do Elementos de Semiologia de Barthes.

Enfim, permitamo-nos maravilharmo-nos com o fantástico Kaspar Hauser de Izidoro Blikstein.

\section{b) A língua}

Kaspar Hauser ou a fabricação da realidade, é este o título do livro de Izidoro Blikstein, livro que será tratado no presente capítulo. O nome próprio “Kaspar Hauser” é posto pelo título como alternativa sinonímica à expressão substantiva "a fabricação da realidade". Ou 
seja, falar sobre Kaspar Houser é o mesmo que falar sobre a fabricação da realidade. No entanto, quem é Kaspar Hauser? E o que poderia ser a fabricação da realidade?

Kaspar Houser é o personagem principal do filme "O enigma de Kaspar Hauser" (“Jeder für sich und Gott gegen alle", título original em alemão); alguém que viveu trancafiado num sótão sem qualquer tipo de interação humana até os dezoito anos e, após esse interstício, foi enviado para a cidade de Nuremberg, onde foi acolhido por um criminalista e então aprendeu a língua falada naquela sociedade. Kaspar Hauser, contudo, mesmo após aprender a língua falada a seu redor, mostrou-se incapaz de compreender a realidade a seu redor da mesma forma que os demais, a seu redor, a compreendiam. Este fato motivou a seguinte questão levantada por Blikstein: se Kaspar Hauser, a despeito de falar a mesma língua, não consegue atingir uma mesma compreensão da realidade, o que estaria ausente entre a realidade e a compreensão? A resposta: a carência de contato humano em seu desenvolvimento deixou em Kaspar Hauser uma deficiência (comparativamente aos demais habitantes de Nuremberg) de percepção-cognição; portanto, apesar de falar a mesma língua, não possui os mesmos padrões de percepção, que só são adquiridos com o exercício da práxis social. É essa incompatibilidade de percepções que, segundo Blikstein, torna marcante o filme de Kaspar Hauser, devendo guiar sua interpretação ao assumir o papel de isotopia semântica.

\footnotetext{
Subversão de nosso aparelho perceptivo-cognitivo: esta deve ser a isotopia básica a iluminar a significação mais profunda da história de Kaspar Hauser, vista por W. Herzog. De fato, pior do que os enigmas atirados ao espectador, é o estranho mundo em que se vê, de repente, plantado, atônito, perplexo, o próprio Kaspar Hauser. Seu olhar fixo diante de pessoas, ruas, casas, objetos, paisagens. Tudo assusta. As dimensões, os movimentos, a lógica, a perspectiva, o pensamento, a fala, o riso. (1985, p. 12).
}

E a subversão do nosso aparelho perceptivo-cognitivo mostra-se também como o propósito de Blikstein. Consciente de sua consciência e da inconsciência de grande parte de quem já leu e de quem o lê, Blikstein propõe que manuseemos algo até então rechaçado pela linguística moderna como intangível e incognoscível; propõe que lidemos, de uma vez por todas, com a noção de referente, como algo que é fabricado pela percepção-cognição para assumir o papel de realidade. A fabricação da realidade é a ação da percepção; a percepção fabrica a única realidade que se pode compreender. E no filme "O enigma de Kaspar Hauser" essa função da percepção adquire especial distinção. A peculiaridade da percepção da personagem principal (ou sua carência de percepção) revela o fato de que não é a língua que 
produz a realidade que se pode compreender, mas sim a percepção. Veja: uma diferença de percepção tornou irrelevante a identidade linguística; consequentemente, eventual coincidência na compreensão linguística de uma mesma realidade depende, em primeiro lugar, duma coincidência de percepção. Logo, é a percepção, e não a língua, que fabrica a realidade que só então poderá ser compreendida em termos linguísticos - é essa a tese que Blikstein magistralmente sustenta e que passo, finalmente, a expor.

\begin{abstract}
Apesar de explicado pela linguagem, pelas palavras, por signos linguísticos, enfim, a paisagem em que foi colocado Kaspar Hauser permanece turva e indecifrável. Tão turva quanto as sombras que se movem nos desertos de seus pesadelos. Conhecer o mundo pela linguagem, por signos linguísticos, parece não bastar para dissolver o permanente mistério e a perplexidade do olhar de Kaspar Hauser. Talvez porque a significação do mundo deve irromper antes mesmo da codificação linguística com que o recortamos: os significados já vão sendo desenhados na própria percepção/cognição da realidade. (1985, p. 17).
\end{abstract}

Se Blikstein propõe a percepção-cognição como fabricante da realidade, fá-lo para opor-se à ideia, propagada por extensa e consolidada corrente da linguística moderna, de que é a língua a única responsável por recortar a realidade e formar o pensamento.

\begin{abstract}
$\mathrm{Na}$ linguística moderna, entretanto, a tendência dominante tem sido considerar a língua como organizadora da estrutura conceitual do universo e já se tornou lugarcomum afirmar que ela é "o molde do pensamento", ou "o instrumento de análise ou recorte da realidade" (cf. famigerada expressão da semiologia francesa: "découpage de la réalité"); trata-se, em última análise, da tese clássica de W. von Humboldt, para quem a língua é "o órgão construtor do pensamento" ("das bildende Organdes Gedanken"). Na esteira de Humboldt, linguistas de diferentes "escolas" reafirmariam o primado da língua na montagem do pensamento e da significação do mundo. (1985, p. 39/40, itálicos no original).
\end{abstract}

Ao atribuir à língua a primazia da captura da realidade, essa corrente dominante propõe a compreensão da realidade cognoscível como algo essencialmente linguístico, isto é, interno à língua, e, consequentemente, descarta a realidade que pode ser percebida antes mesmo da incidência da língua. Blikstein ilustra a proposta dessa corrente dominante partindo de Ogden e Richards e seu famoso triângulo até chegar em Umberto $\mathrm{Eco}^{40}$. Partamos também do triângulo

\footnotetext{
${ }^{40}$ Sendo que, entre estes dois autores estão, por exemplo, Ullmann, Baldinger, Benveniste, Barthes e outros tantos. Ver capítulos III até VI (1985).
} 
de Ogden e Richards para esclarecer a oposição entre realidade linguística e realidade extralinguística.

Figura 1 - O triângulo de Ogden e Richards

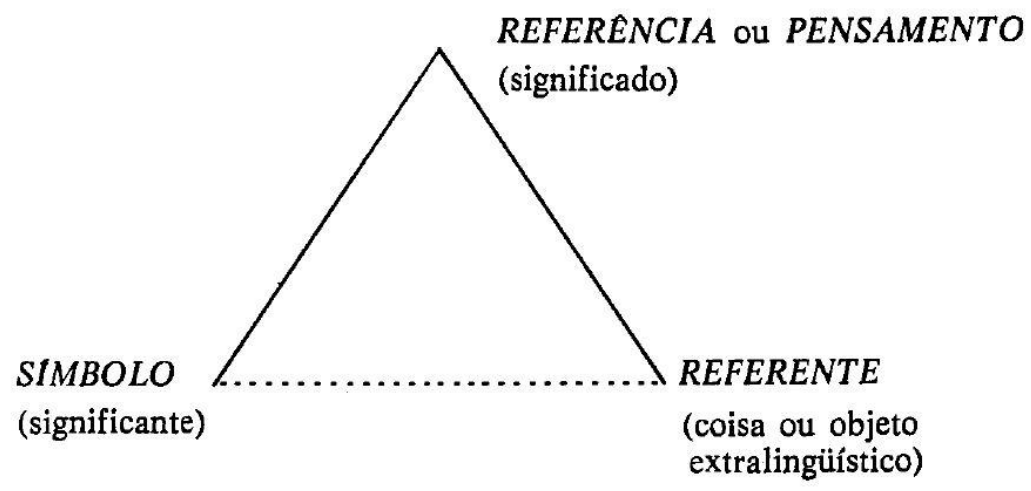

Fonte - Blikstein (1985, p. 24)

O diagrama triangular ilustra um símbolo (ou significante) linguístico que possui uma relação direta com uma referência linguística (ou pensamento ou significado) e uma relação apenas hipotética com um referente, uma coisa ou objeto extralinguístico (existente na realidade extralinguística). Há ainda a relação qualificada como "mais ou menos" direta entre referência e referente ${ }^{41}$. Segundo Ogden e Richards, somente a relação entre símbolo e referência é de fato relevante; por conseguinte, preocupam-se exclusivamente com a correção e a lógica de tal relação, examinando as condições de verdade do símbolo (equivalência entre símbolo e pensamento) e as influências exercidas pela língua sobre o pensamento (símbolo formando o pensamento).

Em suma, a realidade extralinguística não seria decisiva para a articulação do significado dos signos; o que importa é que a relação entre símbolo e referência seja correta e até lógica. Tal postura "logicista", vai levar, inevitavelmente, à expulsão do referente; com efeito, para Ogden e Richards, "a teoria das relações diretas entre palavras e coisas é a origem de quase todas as dificuldades com que o pensamento se defronta..." e, na medida em que procuram elaborar uma doutrina das condições formais de verdade dos símbolos (ou signos), a sua obra constitui "uma tentativa de

${ }^{41}$ Ver itens das páginas 24 e 25 (1985). 
enfrentar as dificuldades suscitadas pela influência da linguagem sobre o pensamento". (1985, p. 25, itálicos no original).

Após a exposição da teoria de Ogden e Richards, Blikstein cita as atualizações promovidas, individualmente, por Ullmann, Baldinger e Eco sobre o triângulo. Afirma, contudo, que nenhuma das atualizações possuiu qualquer condão evolutivo, pois apenas acrescentaram (ou renomearam) conceitos em cada vértice do triângulo. Por outro lado, todos mantiveram a e insistiram na afirmação de que para a linguística deve interessar unicamente o lado esquerdo do triângulo, qual seja, a face entre os vértices "símbolo" e "referência"42.

Pois bem, lidar somente com o símbolo e sua referência é, como já afirmado, pôr para fora da linguística o referente; é expulsar da esfera de cogitações linguística tudo aquilo que possa ser relacionado à ideia de realidade extralinguística. Com essa expulsão do referente e da realidade extralinguística, é a referência que passa a exercer o papel de "realidade" fabricada (uma realidade essencialmente linguística, ou seja, fabricada pela língua); afinal, o símbolo ainda tem de se referir a algo. Em outros termos, o símbolo representa algo além de si, uma realidade além de si; se essa realidade não é extralinguística, pois tal coisa ou não existe, ou é incognoscível, ela só pode ser linguística, recortada e formada pela língua mesma e denominada de referência. Mas sobre o que a língua efetua esse recorte para criar sua realidade, sua referência; o que a língua recorta? A resposta está no próprio triângulo: a língua recorta o pensamento, estruturando-o como referência e, com isso, transformando-o em algo linguístico. São as unidades de referência recortadas no pensamento que passam a ser representadas por unidades simbólicas. Desse modo, o ciclo, em tese, se fecharia: a língua estrutura sua realidade a partir do pensamento criando uma referência intralinguística para seus símbolos. Logo, a relação pretensamente direta e autossuficiente entre símbolo e referência torna irrelevante o referente, que pode ser descartado.

Para falar, a partir de agora, especificamente sobre significação, substituirei os conceitos de "símbolo" e "referência" por seus sinônimos, também apontados pelo triângulo de Ogden e Richards: "significante" e "significado". O fechamento intralinguístico pressupõe que o conjunto de significados é a única "realidade" a que os símbolos (significantes) podem se referir. Tudo o que pode ser significado só pode sê-lo através de uma língua, pois nela já

\footnotetext{
42 Blikstein, falando especialmente sobre Eco, mas citando também Ullmann: “A ótica de Eco é praticamente a mesma de Ogden e Richards/Ullmann, porquanto a sua atenção está voltada para a relação experiência verbal/unidade cultural, que corresponde, em última análise, a símbolo/referência (significado), ou melhor... o 'lado esquerdo' do triângulo!" (1985, p. 36, itálicos no original). Sobre a ausência de evolução e o prestígio da face esquerda do triângulo por parte de Baldinger, ver página n. 30 (1985).
} 
encontra-se previamente articulado numa relação existente entre um significante e um significado. Significar é fazer referência a um significado através de um significante; e a significação é o ato de significar.

Essa corrente combatida por Blikstein ainda traz a seguinte proposta: se a língua é a matriz da significação (os significados e os significantes são sempre articulados pela língua), tudo o que eventualmente venha a assumir caráter significativo só poderá ser compreendido (interpretado) através da língua. A língua é o interpretante primordial, a única fonte de significação: nada significa senão no interior da língua ${ }^{43}$. Blikstein, contudo, faz a seguinte ressalva:

\begin{abstract}
Mas esse poder "interpretante" da língua parece não abarcar os enigmas de Kaspar Hauser, cuja compreensão do mundo esbarra antes na dimensão perceptivo-cognitiva. Se a língua é o "molde" ou a grande "matriz semiótica" da sociedade, é necessário reconhecer que a experiência perceptiva já é um processo (não-verbal) de cognição, de construção e ordenação do universo. (...). Pois é esta face ainda obscura do mecanismo de significação que importaria esclarecer primeiro: como percebemos o mundo, as "coisas", a "realidade"? Com o medo de resvalar em "psicologismos" ou em "antropologismos", linguistas e semiólogos têm sido refratários ao exame da percepção da "coisa" extralinguística. Parece-nos que delegar tal investigação a outras disciplinas, ficar à margem da relação (obrigatória!) entre percepção/cognição e significação linguística, como se a semiologia bastasse a si mesma apenas com o lado esquerdo do triângulo de Ogden e Richards, é enxergar apenas uma face do evento semântico. (1985, p. 42, itálicos no original).
\end{abstract}

Ou seja, a pretensa autossuficiência da língua não é suficiente para explicar por que Kaspar Hauser não consegue compreender até as mais singelas coisas do mundo da mesma forma que os demais falantes da língua. Ele encontra significados para significantes, mas significados diferentes dos que o restante da sociedade de Nuremberg encontra para os mesmos significantes. Para Blikstein, isso é evidência de que o evento semântico (a significação) não é um fenômeno exclusivo da língua; a significação não começa e termina no interior da língua, ela começa sim num âmbito anterior à língua para só então terminar na língua. E esse âmbito é a dimensão perceptivo-cognitiva. Por esse motivo, Blikstein diz que é inevitável, para a linguística que queira compreender completamente o fenômeno semântico, deixar de lado os velhos preconceitos e passar a considerar também a percepção-cognição como produtora da significação.

\footnotetext{
${ }^{43}$ Ver citações de Roland Barthes e de Émile Benveniste, p. $41 / 42$ (1985).
} 
A semiologia, destarte, parece não conseguir livrar-se do referente: conceito, objeto mental, unidade cultural... há sempre algo atrás do signo, "extralinguístico", que, situado na dimensão perceptivo-cognitiva, está na base da produção do evento semântico. Todos esses impasses parecem decorrer de um equívoco fundamental: o fato de o referente ser extralinguístico não significa que deva ficar fora da linguística; ele simplesmente está situado atrás ou antes da linguagem, como um evento cognitivo, produto de nossa percepção. Qualquer que seja o nome de tal "produto", seja referente, objeto mental ou unidade cultural, fica reconhecida a necessidade do recurso a uma dimensão anterior à própria experiência verbal para a detecção da gênese do significado. Tal dimensão, que não será a realidade "tout court", é a percepção-cognição, onde justamente se fabricam os referentes/objetos mentais/unidades culturais; estes é que, embora desprovidos de estatuto linguístico propriamente dito, condicionarão o evento semântico. (1985, p. 38/39, itálicos no original).

Esse pequeno trecho é extremamente relevante. Blikstein nota que a corrente dominante da linguística moderna, apesar de não poupar esforços - e fazer questão de explicitar esses esforços - para justificar a significação independentemente da ideia de referente, sempre se vale de algum conceito minimamente enraizado na noção de realidade extralinguística (no trecho citado ele exemplifica com os conceitos de objeto mental, de Baldinger, e unidade cultural, de Eco $)^{44}$. Portanto, o que é inelutável transforma-se em indispensável: é indispensável que a linguística lide com a noção de referente, com a noção de realidade extralinguística que, não obstante extralinguística, é diretamente relacionada à língua e à significação.

\begin{abstract}
A linguística deveria, a meu ver, voltar mais a sua atenção para a natureza da experiência perceptivo-cognitiva e procurar detectar a função e o papel desta na configuração do "real" bem como na arquitetura conceitual de nosso pensamento. Seria na percepção-cognição, portanto antes mesmo da própria linguagem, que se desentranhariam as raízes da significação. (1985, p. 39).
\end{abstract}

Blikstein ressalta, entretanto, que essa realidade (o referente) fabricada pela percepção-cognição não se confunde com a realidade propriamente dita ("tout court"). $\mathrm{O}$ referente fabricado como realidade extralinguística é um nível intermediário entre a língua e a realidade propriamente dita $^{45}$; ou seja, o referente é a forma como a realidade propriamente dita é percebida pela percepção-cognição, é o produto da fabricação realizada pela percepçãocognição, que tem como matéria prima a realidade propriamente dita. Destarte, prestigiar o

\footnotetext{
${ }^{44}$ Ver capítulos III até VI (1985).

${ }^{45}$ Ver gráfico n. 7 na p. 46 (1985).
} 
referente como realidade fabricada pela percepção-cognição não é trazer a realidade propriamente dita para o universo da linguística (já que continua compreendida como inacessível), mas trazer uma realidade extralinguística, porém acessível, que influencia deveras o fenômeno da significação.

Com tal deslocamento de perspectivas teóricas, linguistas e semiólogos deveriam alargar a sua metodologia de análise, voltando-se agora também para o lado direito do triângulo de Ogden e Richards - em que se coloca o referente - e explorando o mecanismo pelo qual a percepção/cognição transforma o "real" em referente. O triângulo passaria a ter uma configuração semiológica mais abrangente; a realidade se transforma em referente, por meio da percepção/cognição (conforme Greimas) ou da interpretação humana (segundo Coseriu), e o referente será obrigatoriamente incluído na relação triádica: (1985, p. 46, itálicos no original)

Esse caráter intermediário do referente (posicionado entre realidade "tout court" e língua) demonstra quão equívoca é a ideia de que "a língua recorta a realidade"; na verdade, a língua não recorta a realidade propriamente dita, mas a realidade produzida pela percepçãocognição: a língua recorta o referente ${ }^{46}$. Essa anteposição do referente relativamente à língua lhe confere, senão predominância, extrema relevância no processo de significação (ou semiose). Porém, Blikstein não se limita a apontar que a significação resulta da inter-relação entre língua e referente, sendo este anterior àquela; vai ainda mais fundo para descobrir (a) os mecanismos que permitem à percepção-cognição transformar a realidade propriamente dita em referente e também (b) como a movimentação de tais mecanismos já constitui o primeiro germinar da significação ${ }^{47}$.

Lembrando novamente de Kaspar Hauser, do fato de não ser capaz de compreender a "realidade" do mesmo modo que os demais habitantes de Nuremberg e de seu déficit perceptivo-cognitivo provocado por seu desenvolvimento em isolamento, Blikstein afirma que a percepção-cognição é modelada por uma práxis social. A convivência em sociedade é que uniformiza a percepção-cognição e faz com que os falantes que vivenciam uma mesma práxis fabriquem o referente de forma também uniforme. Como Kaspar Hauser não viveu a e na sociedade de Nuremberg, não é capaz de perceber a realidade da mesma forma que os demais

\footnotetext{
46 “O percurso semiológico acima descrito mostra a precariedade do clichê 'a língua recorta a realidade’: ela não recorta a realidade propriamente dita, mas o referente... ou a realidade 'fabricada'." (1985, p. 47)

47 "Esse avanço epistemológico não explica tudo. A semiologia deveria ir mais longe, procurando compreender os mecanismos de transformação da realidade em referente." (1985, p. 49).
} 
falantes da língua em comum, não é capaz de fabricar referentes semelhantes aos fabricados pelos demais falantes.

\begin{abstract}
Sabemos que, do nascimento à maturidade, Kaspar Hauser esteve isolado de qualquer contexto ou prática social; pois bem, o que podemos verificar na sua experiência é que, a despeito da ação da linguagem (adquirida na fase adulta) ou de uma eventual organização mental inata, Kaspar Hauser não consegue captar o mundo como o faz a sociedade que o cerca. Fica evidente então que seu sistema perceptual está desaparelhado de uma prática social. E é nessa prática social ou práxis que residiria o mecanismo gerador do sistema perceptual que, a seu turno, vai "fabricar" o referente. (1985, p. 52/53, itálicos no original).
\end{abstract}

O conceito de práxis social é definido como a ação humana e interativa que proporciona as condições de existência numa sociedade ${ }^{48}$. A práxis ilustra um processo de aprendizado/conhecimento concretizado na vivência de mundo e na convivência com aqueles que vivem o e no mundo. É essa vivência e essa convivência que modelam de forma equânime a percepção-cognição e permitem a mútua compreensão no interior da sociedade, viabilizando sua existência. A práxis, portanto, submete tanto a percepção-cognição quanto a língua, sendo diretamente influente na forma como a primeira irá fabricar o referente e no modo como a segunda irá compreender a realidade que lhe é externa, pois posta como referente. "A lição clássica acerca das relações linguagem/percepção/realidade deveria ser então reformulada: a percepção e a linguagem é que estariam indissoluvelmente ligadas à práxis social, que é indefectível e vital para a existência de qualquer comunidade.” (1985, p. 58, itálicos no original).

Mas como se dá a modelagem da percepção-cognição pela práxis social? Blikstein traça todo um percurso para demonstrar como os elementos da práxis vão progressivamente modelando a percepção-cognição e despertando os primeiros lampejos de significação. Vejamos esse percurso nas palavras de Blikstein ${ }^{49}$ :

\footnotetext{
48 "Por outro lado, a expressão prática social funciona, em nosso esquema, com o sentido já consagrado no marxismo, ou seja, o de práxis: conjunto de atividades humanas que engendram não só as condições de produção, mas, de um modo geral, as condições de existência de uma sociedade.” (1985, p. 54, itálicos no original).

${ }^{49}$ A citação é um pouco longa, contudo, é incrivelmente esclarecedora. De todo modo, acredito que qualquer tentativa de resumir esse percurso da práxis acarretaria a perda de informações inestimáveis para a compreensão do que virá a seguir. Vale destacar, como Izidoro o faz, que esse percurso da práxis foi imaginado através da articulação de conceito que encontrou em A. Schaff e A. J. Greimas (ver p. 60/61 e também nota 82, encontrável na p. 93, sobre o termo "isotopia").
} 
A partir das considerações acima, parece-nos razoável supor que, na dimensão da práxis vital, o homem cognoscente desenvolve, para existir e sobreviver, mecanismos não-verbais de diferenciação e identificação: para mover-se no tempo e no espaço de sua comunidade, o indivíduo estabelece e articula traços de diferenciação e de identificação, com os quais passa a discriminar, reconhecer e selecionar, por entre os estímulos do universo amorfo e contínuo do "real", as cores, as formas, as funções, os espaços e os tempos necessários à sua sobrevivência. Discriminatórios e seletivos que são, tais traços acabam por adquirir, no contexto da práxis, um valor positivo ou meliorativo em oposição a um valor negativo ou pejorativo; assim é que os traços de diferenciação e identificação, impregnados de valores meliorativos/pejorativos, se transformam em traços ideológicos. E aqui eclode a semiose: os traços ideológicos vão desencadear a configuração de "fôrmas" ou "corredores" semânticos, por onde vão fluir as linhas básicas da significação, ou melhor, as isotopias da cultura de uma comunidade. Em nossa cultura, por exemplo, "em pé" ou "vertical” é um traço de valor meliorativo, enquanto "deitado" ou "horizontal" teria, em princípio, um valor pejorativo; a partir de tais traços ideológicos, constituem-se os corredores semânticos ou isotópicos da verticalidade meliorativa vs. horizontalidade pejorativa. Assim, na arquitetura das catedrais góticas, das pirâmides maias ou dos arranha-céus dos centros urbanos ocidentais, a verticalidade é um índice evidente da "superioridade" ou da "majestade". Ainda a título de exemplo, vale lembrar outros grandes corredores isotópicos que recortam o universo de formas, cores, e espaços, em nossas comunidades ocidentais: superatividade (meliorativo) / inferatividade (pejorativo), frontalidade (meliorativo) / posterioridade (pejorativo), retitude (meliorativo) / tortuosidade (pejorativo), dureza (meliorativo) / moleza (pejorativo), branquitude (meliorativo) / pretitude, negritude (pejorativo) etc.

São justamente esses corredores semânticos ou isotópicos que vão balizar a percepção/cognição, criando modelos ou padrões perceptivos, ou ainda os "óculos sociais", na expressão de Schaff:

“...o indivíduo percebe o mundo e o capta intelectualmente através de 'óculos sociais" "...

Esses padrões perceptivos ou "óculos sociais" constituem, em última análise, os estereótipos de percepção. Pois bem, com os estereótipos gerados pelos corredores isotópicos é que "vemos" a realidade e fabricamos o referente. (1985, p. 60/62, itálicos no original).

Essa passagem descreve uma verdadeira dança dançada por duas protagonistas, a práxis e a percepção-cognição, mas conduzida pela primeira, cujos passos são delicada e dedicadamente seguidos pelos passos da segunda que, assim, cada vez mais, aperfeiçoa-se no ato de dançar e, cada vez menos, tropeça em seus próprios passos. A práxis modela a percepçãocognição (o modo como esta performa sua dança num tempo e num espaço) desde seu primeiro contato com o mundo: quando nada ainda é conhecido, mas tudo é cognoscível. Neste estado primitivo, só o que ordena a percepção é a intenção instintiva de sobrevivência, a intenção de seguir o que é agradável e afastar o que é prejudicial; e é a práxis que atira em direção à percepção-cognição tudo que pode ser experimentado e gostado ou desgostado. $\mathrm{O}$ gostoso e o desgostoso são mecanizáveis de forma ainda não-verbal através da identificação das semelhanças e das diferenças que permitem agrupá-las. O bom assemelha-se ao bom e diferencia-se do mau, enquanto o que assemelha coisas más distingue-as das coisas boas. As semelhanças e diferenças são mecanizadas em traços de diferenciação e identificação que, 
quando qualificados em bons ou maus, assumem o papel perceptivo-cognitivo de traços ideológicos. Os traços ideológicos são, portanto, os eixos de semelhanças e diferenças que permitem classificar coisas boas como boas e coisas más como más e, com isso, permitem também o reconhecimento de tais coisas pela percepção sem que uma nova experimentação prática seja sempre necessária. E é nessa transformação de traços de identificação em traços ideológicos que surgem as primeiras centelhas de significação: ainda que ainda fora da língua, a formação de um traço ideológico já representa a atribuição de um significado (bom/mau) a um traço perceptivo-cognitivo. Por esse motivo as articulações entre traços ideológicos de valores perceptivo-cognitivo opostos (traço meliorativo/traço pejorativo) são denominadas de corredores semânticos. Tais articulações reúnem traços que apresentam alguma forma de identidade, mas que se diferem em sua definição perceptivo-cognitiva (meliorativa/pejorativa), isto é, diferem-se segundo o significado que é atribuído pela percepção-cognição. A denominação de corredor semântico é ilustrativa por si: é por seu meio que os estímulos (as coisas do mundo) que atingem a percepção-cognição são interpretados em bons ou maus, em meliorativos ou pejorativos. A tendência perceptivo-cognitiva é a consolidação dos corredores semânticos que, por esse motivo, podem ser chamados também de corredores isotópicos. As isotopias de percepção-cognição têm o condão de tornar o mundo já conhecido sempre reconhecível, sempre já previamente interpretado, não mais assustador. O mundo passa a ser sempre o mesmo, sempre percebido e conhecido do mesmo modo, pelos mesmos “óculos sociais" que constrangem a percepção-cognição e impedem que algo já percebido e conhecido venha a ser percebido e conhecido de outro modo. $\mathrm{O}$ conjunto de corredores semânticos/isotópicos cria esses óculos sociais, também denominados de estereótipos de percepção e, com isso, uniformizam a fabricação do referente que será posto para a língua como a realidade percebida e conhecida.

Esse longo percurso iterativo entre práxis e percepção-cognição foi proposto por Blikstein como forma de demonstrar o quanto se perde em termos de compreensão da significação se se opta por afastar da linguística o estudo a questão do referente. A percepçãocognição mostra-se estruturada por elementos significativos que, apesar de não-linguísticos, influenciam diretamente a significação (semiose). Ou seja, a percepção-cognição - e essa é a questão - é significativa mesmo sem a intercessão da língua; o fenômeno da significação germina já na percepção-cognição e independentemente da incidência das estruturas linguísticas. 
Todo esse processo - da práxis ao referente - desenvolve-se, em princípio, numa dimensão não-verbal, sem a intervenção obrigatória da língua. A práxis opera em nosso sistema perceptual, ensinando-nos a "ver" o mundo com os "óculos sociais" ou estereótipos e gerando conteúdos visuais, tácteis, olfativos, gustativos, na dimensão cinésica e proxêmica (gestos, movimentos, espaços, distâncias, tempo etc.), independentemente da ação e do recorte da linguagem linear. Discordamos, pois, de A. Schaff, quando nos diz que os elementos de orientação pré-verbal, diante do pensamento linguístico, são "secundários". Na verdade, há todo um universo de significação implicado na dimensão não-verbal da percepção/cognição e que é gerado no trajeto práxis-estereótipo-referente. (1985, p. 65/66, itálicos no original).

Contudo, se a significação germina já na percepção-cognição em forma de estruturas (traços) que são repetidamente percebidas, ensejando assim a formação dos estereótipos de percepção; a repetição que caracteriza esse germinar da significação pré-verbal é também o que permite sua descaracterização.

A formação dos estereótipos de percepção marca a consolidação da modelagem que a práxis exerce sobre a percepção-cognição. Quando a modelagem é estabilizada, a percepçãocognição passa a "ver" a realidade sempre do mesmo modo (sempre através dos óculos sociais ou estereótipos da percepção) e, consequentemente, a fabricar sempre o mesmo referente. E fabricar sempre o mesmo referente é também, e mesmo antes, basear-se sempre na mesma significação pré-verbal (nos mesmos corredores semânticos). O acúmulo progressivo de estereótipos de percepção produz uma circularidade: chega-se ao ponto em que praticamente tudo que pode ser percebido-conhecido já foi percebido-conhecido. E se se chega ao ponto em que nada mais surpreende a percepção-cognição, chega-se também ao ponto em que nada mais surpreende a compreensão linguística - os referentes que apresentar-se-ão para a compreensão serão sempre os mesmos. Como resultado: a língua adquire a soberania da significação, pois absorve as estruturas de significação pré-verbal fabricadas pela percepção. A significação préverbal é descaracterizada, pois absorvida pela língua. Vejamos como Blikstein nos alerta sobre essa questão:

Mas vale observar que, embora a práxis não-verbal desempenhe um papel fundamental no processo da significação (semiose) e na percepção/cognição, o seu alcance será ofuscado pela língua, o mais abrangente dos sistemas semiológicos; (...). (...).

É inegável que, quanto mais avançamos no processo da socialização, mais os códigos verbais se apropriam de nosso sistema perceptual e de nosso pensamento. Todavia, essa exaltação do poder modelante (óbvio, aliás!) dos sistemas linguísticos tem eclipsado a função capital e primeira da práxis na construção da significação. (1985, p. $66 / 67$, itálicos no original). 
Avançar em direção à socialização é caminhar em direção a uma realidade em que a práxis apresenta-se completamente previsível. A práxis só será novidade para quem nascer nessa sociedade. Depois de aprendida, acostumada, e depois de modelada a percepçãocognição, tudo se tornará inabalável: cultura, língua, espaço, tempo, pessoas... Tudo que se puder conhecer já terá sido conhecido, e nada se alterará sem que se mantenha. Se nada é novo e nada mais será novo, mas tudo de novo, tudo poderá ser apropriado pela língua, que compreende não somente o que há, mas também o que haverá de ser compreendido. E se tudo pode ser compreendido pela língua, não há nada que signifique fora dela: ela é a senhora da significação. $\mathrm{O}$ avanço da socialização cria a circularidade; e a circularidade encobre e oculta a percepção-cognição que, não obstante, remanesce existindo, porém, como se não existisse.

Pois é essa dimensão semiológica oculta, entre a práxis e o referente, que escapa a Kaspar Hauser. Assim é que ele chega a Nurembergue, apenas com o seu olhar, desprovido de "óculos sociais”. Sem práxis, sem estereótipos, a sua aproximação cognitiva da realidade é direta: para Kaspar Hauser, não haveria referente ou realidade fabricada, o que o leva a ver o mundo como um amálgama de manchas. (...).

Mas, se Kaspar Hauser não dispõe de estereótipos perceptuais, a sociedade de Nurembergue vai impor-lhe a língua como o grande instrumental cognitivo: sem passar pela práxis, Kaspar Hauser deverá conhecer o mundo através da língua. (1985, p. 76/77, itálicos no original).

Pensando outra vez no caso de Kaspar Hauser, se até sua inclusão na sociedade de Nuremberg jamais havia vivido e convivido socialmente, é certo que jamais havia experimentado qualquer tipo de práxis. Por esse motivo Blikstein afirma que sua percepçãocognição da realidade era direta, pois os estímulos físicos que a atingiam não eram filtrados por quaisquer estereótipos de percepção. A percepção-cognição de Kaspar Hauser era plenamente virgem, não havia sido modelada por nada. Não é demais dizer que seu nascimento - não para a vida, mas para a vida humana - ocorreu no momento da chegada à sociedade de Nuremberg. Quando nasceu para a vida humana, já era um adulto, não teve tempo suficiente para adquirir a práxis daquela sociedade, mas teve-o para adquirir a língua. E foi através da língua que buscou compreender a realidade, “desmanchá-la”, pois via-a como um amálgama de manchas; uma busca que não teve tanto sucesso social, afinal, nunca alcançou compreendê-la do mesmo modo que a sociedade de Nuremberg compreendia.

Não obstante, é notável que a pureza de sua percepção-cognição jamais impediu Kaspar Hauser de compreender, ainda que de forma discrepante, a realidade. A língua sempre 
lhe ofereceu esse suporte. Ou seja, ainda que desprovido de práxis, Kaspar Hauser não estava mais abandonado à nudez compreensiva em que viveu até a socialização; não via mais um amálgama de manchas em que nada é reconhecível ou distinguível. Via signos da língua. Daí a pertinência do caso de Kaspar Hauser, que se mostra útil não apenas para esclarecer o papel inaugural da percepção-cognição no fenômeno da significação, mas também para revelar como a língua é capaz de suprir as lacunas da percepção-cognição. "Lacunas" compreendidas como experiências não experimentadas, práticas não praticadas. A língua preenche tais lacunas e assim também fabrica a realidade; fá-lo por meio de estereótipos verbais (linguísticos) $)^{50}$.

\begin{abstract}
A experiência cognitiva de Kaspar Hauser nos permite, desse modo, divisar com nitidez o momento em que a língua passa a exercer a sua função interpretante ou modelante na percepção/cognição e no pensamento: a impossibilidade de capturar a semiose não-verbal, que se desencadeia na dimensão oculta entre a práxis e o referente, compele o indivíduo a recorrer ao sistema verbal para materializar e compreender a significação escondida. Assim, a língua passa a atuar sobre a práxis, os corredores isotópicos e os estereótipos perceptuais; estabelece-se uma interação entre língua e práxis, a tal ponto que, quanto mais avançamos no processo de socialização, mais difícil se torna separar as fronteiras entre ambas. Agindo sobre a práxis, a língua também pode modelar o referente e "fabricar" a realidade. (1985, p. $79 / 80)$.
\end{abstract}

A língua, portanto, apodera-se progressivamente da percepção-cognição por conta dos dois motivos citados. Primeiro: porque a circularidade da práxis consolida a modelagem da percepção-cognição tornando-a previsível e facilmente absorvível pela língua. Segundo: porque a língua mostra-se cada vez mais (com o avanço do processo de socialização) capaz de suprir as lacunas apresentadas pela percepção-cognição e, com isso, substitui-a no papel de fabricação da realidade.

Mas há ainda um terceiro motivo! Blikstein aponta que é somente através da língua que é possível ter consciência do papel exercido pela percepção-cognição no processo de significação. Isto é, só podemos compreender e explicar algo mediante a intervenção da língua, logo, também a percepção-cognição e seu papel significante só podem ser compreendidos e explicados em termos linguísticos. Eis o que Blikstein denominou de impasse epistemológico: a percepção-cognição produz uma significação independentemente da língua, mas só pode ser significada no interior da língua. Acontece que, por outro lado, a língua é diretamente

\footnotetext{
${ }^{50}$ A expressão "estereótipos verbais" é empregada na citação entre as 119 e 120 desta dissertação, mas a ideia já se aplica neste momento.
} 
alimentada pelos estereótipos da percepção-cognição. Nada existiria na língua se não houvesse existido na percepção-cognição.

\begin{abstract}
Neste esquema, é possível surpreender o impasse epistemológico a que nos condenamos: embora a significação dos códigos verbais seja tributária, em primeira instância, da semiose não-verbal, é praticamente só por meio desses mesmos códigos verbais que podemos nos conscientizar da significação escondida na dimensão da práxis: anterior à língua, a semiose não-verbal só pode ser explicada pela língua. (...). (...).

Falamos em impasse epistemológico, pois, nessa interação língua/práxis, instala-se uma reiteração circular que, em princípio, não pode ser rompida: a práxis cria a estereotipia de que depende a língua e esta, por sua vez, materializa e reitera a práxis. (1985, p. 80).
\end{abstract}

Desenvolvendo um pouco mais esse impasse, temos que: a percepção-cognição é progressivamente modelada pela práxis; a modelagem enseja a formação de estereótipos perceptivos que irão direcionar a fabricação da realidade (referente) pela percepção-cognição; a práxis torna-se cada vez mais circular e repetitiva com o avanço do processo de socialização, o que consolida os estereótipos perceptivos identificáveis na sociedade; a consolidação dos estereótipos permite sua absorção pela língua, que transforma-os em estereótipos verbais; a absorção promovida pela língua concretiza a estereotipação da percepção-cognição.

A estereotipação afasta cada vez mais a realidade propriamente dita da compreensão linguística. Quando na língua se está, o que se pode compreender é sempre algo fabricado pela percepção-cognição, fabricado segundo estereótipos perceptivos. O que se "vê" é sempre filtrado pelos estereótipos. Por conseguinte, no caminho entre a realidade e a língua, intermediado pelo referente fabricado pela estereotipia da percepção-cognição, algo é sempre perdido (retido pelo filtro). O que se perde não é jamais percebido; e o que é percebido constitui o referente, que será tomado pela compreensão como a verdadeira e natural realidade.

A nossa cognição estaria sujeita, portanto, a um processo ininterrupto de estereotipação, a ponto de considerarmos real e natural todo um universo de referentes e realidades fabricadas. Daí a função fascista da linguagem, segundo a expressão de R. Barthes. A língua "amarra" a percepção/cognição, impedindo o indivíduo de ver a realidade de um modo ainda não-programado pelos corredores de estereotipação; como Sísifo, estaríamos condenados a conhecer, ou a reconhecer, sempre a mesma realidade: nossas retinas "fatigadas" estariam condenadas a ver sempre a mesma "pedra-no-meio-do-caminho" de Carlos Drummond de Andrade. Em seu "amarramento" com a práxis, a língua adquire uma função fática compensatória: quando não compreendemos a realidade, utilizamos os estereótipos verbais para 
reiterar o referente ou a realidade fabricada por nossos corredores isotópicos. (1985, p. 82, itálicos no original).

O trecho acima é intrigante e capaz de desesperar até mesmo o mais cético que se proponha a lê-lo. A língua amarra a percepção-cognição, amarra todos que a falam, amarra-os a si mesma, impondo-lhes seus estereótipos verbais. Se a práxis torna-se repetitiva com o avanço da socialização, a língua, de fato, reforça essa repetição criando e impondo uma alienação instrumentalizada pela repetição do mesmo. Com isso, aqueles que falam ignoram a práxis, mas também ignoram a língua, que esconde e se esconde. A língua mostra-se como a mais cruel forma de domínio, sutil e imperceptível.

Haveria escapatória? Haveria como desamarrar essa amarração promovida pela língua? Haveria como enxergar aquém ou além de estereótipos? Blikstein diz que sim. E fundamenta sua afirmação em algo que considero fascinante. Fundamenta a possibilidade de livramento da percepção-cognição através da poesia, da função poética da linguagem:

Mas, como bem notou A. Schaff, a linguagem não é só reflexo, reprodução ou reiteração da práxis. Ela poderá também desenvolver uma ação dialética e criativa na medida em que desarranjar a práxis e os corredores isotópicos e desmontar os estereótipos perceptuais. A linguagem deixa de ser fascista quando, subvertendo a si mesma, subverte a percepção/cognição; (...).

(...).

Para chegar a essa subversão, seria preciso cultivar a função poética da linguagem (já consagrada por R. Jakobson) e, para tanto, basta seguir a receita de Carlos Drummond de Andrade:

"Chega mais perto e contempla as palavras.

Cada uma

Tem mil faces secretas sob a face neutra

E te pergunta, sem interesse pela resposta,

Pobre ou terrível, que lhe deres:

Trouxeste a chave?"

É pela função poética que a linguagem pode subverter a sua estereotipia e entrar numa relação conflituosa e dialética com a práxis. (...).

(...).

No conflito dialético com a práxis, a linguagem criativa e poética vai desmontando os corredores isotópicos e os estereótipos, denunciando assim a fabricação da realidade. Aí ela pode tornar-se uma práxis libertadora. Por isso é que Kaspar Hauser passa a representar um incômodo: ao usar a linguagem para desafiar a percepção/cognição que lhe inculcam, ele acaba por patentear como a realidade tão bem ordenada e natural é apenas um produto da práxis da comunidade de Nurembergue. Kaspar Hauser tornase subversivo quando, ao não aceitar os referentes que a sociedade lhe impõe, abala os fundamentos da ilusão referencial. E é sobretudo por essa práxis libertadora (e não por um mero lance de novela policial) que ele deve morrer. (1985, p. 84/86, itálicos no original). 
É a poesia que desvela os estereótipos perceptivos, é ela que expõe as amarras impostas pelo cruel dominador que é a língua. Ao desvelá-los (os estereótipos), a poesia permite ao poeta usá-los, descartá-los, submetê-los, subvertê-los, enfim, dominá-los. O poeta impõe-se como o senhor da língua, como o verdadeiro senhor da significação. A poesia é o colocar a língua contra si mesma; e ao ser obrigada a enfrentar-se a si mesma, a língua entrega-se, rende-se, deixandose usar por quem a colocou nessa posição. A poesia retrata o ressurgimento da criatividade perdida na estereotipia, a desvinculação da significação e da compreensão. A poesia, portanto, desperta e liberta.

Blikstein encerra o Kaspar Hauser com duas convicções. A primeira: a práxis comunitária, ao modelar a percepção-cognição e ser reforçada pela língua, cria uma "ilusão referencial"; e a ilusão referencial pode ser ilustrada como uma prisão cujas paredes refletem sempre a mesma "realidade" e, com isso, impedem que seus prisioneiros percebam e compreendam qualquer outra "realidade". E a segunda: essa prisão referencial não é inescapável; ela mantém uma porta de fuga que pode ser aberta pela chave da poesia. A poesia abre a porta da liberdade e, finalmente em estado de liberdade, olhando de fora a prisão em que estava, o liberto é capaz de perceber que o que até então percebia era algo fabricado.

São essas duas convicções que, analisadas em conjunto, revelam a interpretação fenomenológica que encontrei em Blikstein. O ser da língua mostra-se em si mesmo como aprisionamento e como iludição. Tanto o ser-aprisionante quanto o ser-ilusório decorrem da estereotipação que a língua realiza e consolida sobre a percepção-cognição. Isto é, a língua, sendo, aprisiona ao tornar repetitiva a vida de quem a fala - aprisiona no mesmo e com o mesmo. Sendo, transmite a sensação de poder àqueles que a falam, que podem tudo compreender sem jamais se surpreender; ilude através da atribuição deste poder irreal, distrativo, enquanto domina tudo que pode ser percebido, conhecido e compreendido - a língua atribui o "poder" de conhecer tudo, mas tudo do mesmo. E como o "mesmo", a repetição ou circularidade, caracteriza tanto o ser-aprisionante quanto o ser-ilusório, ambos poderiam ser resumidos como ser-o-mesmo, ou ser-sempre-o-mesmo.

A língua é um silencioso aprisionamento, intencionalmente imperceptível, que se faz imperceptível ao tornar-se o que há de mais comum na convivência humana. Eis sua beleza... e sua perversidade.

\section{c) E o signo linguístico}


Ao signo linguístico Blikstein não dedicou muitas páginas de seu Kaspar Hauser. O capítulo segundo, por exemplo, que traz o termo "signo" em seu título, possui menos de três páginas completas. Neste capítulo, apresenta a concepção clássica de signo, compreendido como algo que representa as coisas, as coisas da realidade: "O signo seria, afinal, algo que substitui ou representa as coisas, isto é, a realidade.” (1985, p. 20, itálicos no original). Vejamos mais algumas de suas palavras:

O signo representaria a realidade extralinguística e, em princípio, é por meio dele que podemos conhecê-la. A Kaspar Hauser, por exemplo, impingiam todos os tipos de signos, na certeza de que ele compreenderia o insólito ambiente que o cercava. Cabe observar que essa inculcação semiológica não ocorre apenas com Kaspar Hauser: de um modo geral, todo processo educativo e de socialização é tributário da representatividade do signo; vale dizer que a educação, via de regra, não passa de uma construção semiológica que nos dá a ilusão da realidade. (1985, p. 21).

O signo, portanto, é o elemento linguístico que representa a realidade extralinguística. Aprender uma língua é aprender um conjunto semiológico, ou seja, um conjunto de signos que representam a realidade extralinguística. E essa realidade extralinguística, como explicado acima, é o que Blikstein denominou de referente, o qual definiu como o produto da percepçãocognição (ou a "realidade" fabricada pela percepção-cognição). Se o referente é a realidade extralinguística, o signo é o elemento linguístico que representa algo do referente.

Pensando novamente no triângulo de Ogden e Richards ${ }^{51}$, tão trabalhado por Blikstein, temos que o signo abrange a face esquerda do triângulo: a relação entre significante e significado (ou entre símbolo e referência), pois que tanto significante quanto significado são elementos linguísticos (unidos pela língua para formar os signos). Mas se a face esquerda do triângulo delimita sua espacialidade linguística, ela ainda aponta para o referente como algo representado pelo signo.

Ao buscar demonstrar a relevância do referente no processo de significação, Blikstein fez uma proposta completamente oposta à que a corrente dominante da linguística moderna então fazia (conforme explicado acima, essa corrente dizia que a face direita do triângulo deveria ser ignorada). A proposta foi: sintetizar a face esquerda num único termo, o termo "língua", e manter o termo "referente" para denominar a realidade extralinguística representada pela língua. Com isso, o triângulo foi desestruturado. Em seu lugar surgiu uma relação bipolar,

\footnotetext{
${ }^{51}$ Ver ilustração presente na página n. 108 deste capítulo.
} 
uma relação entre língua e referente. Nessa relação, a língua aparece como conjunto de signos que representam as coisas do referente; e o referente aparece como a realidade extralinguística fabricada pela percepção-cognição. Essa redução do triângulo a uma relação bipolar foi ilustrada pelo seguinte diagrama:

Figura 2 - A iteração língua/práxis

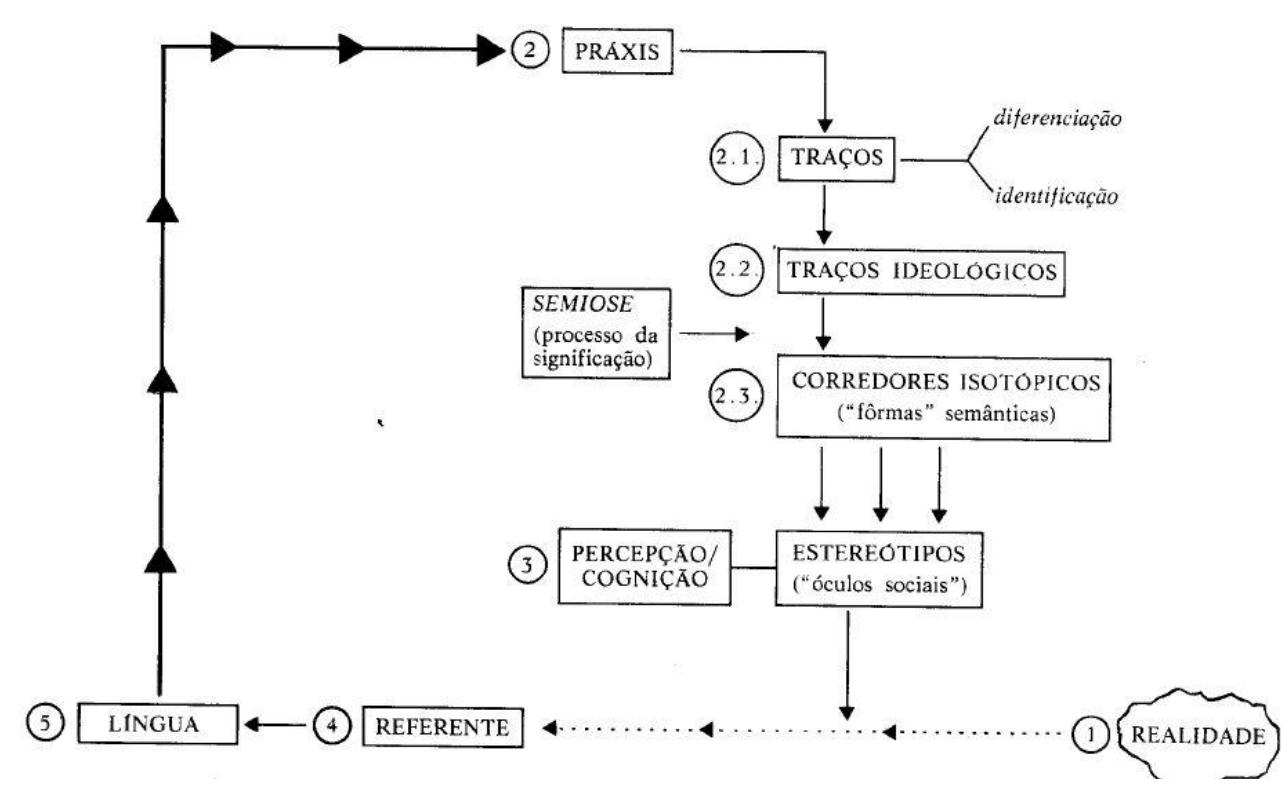

Fonte - Blikstein (1985, p. 81).

Assim, se nos primeiros gráficos em que a percepção-cognição e a práxis foram ilustradas o triângulo ainda era retratado ${ }^{52}$, nesse gráfico final ele foi substituído pela relação horizontal e exclusiva entre língua e referente.

Nesse ponto, e pensando novamente no signo linguístico, cabe questionar: o que o abandono do triângulo poderia significar? Afinal, com o abandono, a relação entre significante e significado, que define o signo linguístico, também deixou de ser ilustrada. Teria então o signo perdido relevância para Blikstein? Acredito que não. Como afirmado, a substituição do triângulo por uma relação entre "língua" e "referente" almejou destacar o papel exercido pelo segundo termo no nascimento da significação. E nessa substituição, o signo linguístico

52 Ver, por exemplo, o gráfico ilustrado na página n. 53 (1985). 
(significante-significado) foi absorvido pelo termo "língua"; ou seja, ainda que não mais ilustrado, o signo remanesce como elemento que constitui a língua enquanto um sistema (de signos).

Pois bem, é possível agora finalmente dizer que foi nessa passagem proposta por Blikstein - a passagem da relação constitutiva do lado esquerdo do triângulo para a relação entre língua e referente - que encontrei o que considero uma interpretação fenomenológica do signo linguístico. Essa passagem ilustra o aparecimento do mostrar-se em si mesmo do ser do signo linguístico como instrumentalidade, como ser-para, como algo que serve para uma finalidade. No caso do signo linguístico, como algo que serve para a língua (ser-para-a-língua). O signo linguístico, sendo, instrumentaliza o modo de ser da língua, que se mostra em si mesmo, como afirmado acima, como aprisionamento e iludição. Em outros termos, para aprisionar e iludir, a língua vale-se do signo linguístico.

Esse modo de ser instrumental pode ser um tanto mais esclarecido se relembrarmos a definição que Blikstein conferiu ao signo linguístico. Definiu-o como como algo que substitui ou representa as coisas do referente (a realidade extralinguística fabricada pela percepçãocognição). Em relação ao referente, o signo impõe-se, põe-se ativamente, não passivamente. $O$ substituir é o colocar-se no lugar de algo, é o substituir algo por si. E o representar é o colocar atrás de si, é o esconder atrás de si, é o fazer-se notar no lugar do que se representa perante aquele para que se representa. O signo, portanto, ao substituir ou representar o referente, ou põe-se no lugar do referente ou esconde-o atrás de si, enquanto apresenta-se como referente.

Portanto, é essa capacidade de substituir e/ou representar que permite à língua, ao empregar os signos, dominar a percepção-cognição, estereotipá-la e, consequentemente, aprisionar e iludir aqueles que a falam. São os signos que, como células do organismo língua, consolidam os estereótipos perceptivos, pondo-se em se lugar, e apresentam-se como estereótipos (verbais) nas eventuais ausências de estereótipos perceptivos. Uma vez na língua, e quando não se recorre à poesia, o que se pode compreender são os signos linguísticos, e os signos linguísticos são, confortável ou aflitivamente (?)... sempre os mesmos. 
PARTE III

CONSIDERAÇÕES FINAIS 


\title{
Capítulo único.
}

\author{
O mistério das cousas, onde está ele? \\ Onde está ele que não aparece? \\ Pelo menos a mostrar-nos que é mistério? \\ Que sabe o rio disso e que sabe a árvore? \\ E eu, que não sou mais do que eles, que sei disso? \\ Sempre que olho para as cousas e penso no que os homens pensam delas, \\ Rio como um regato que soa fresco numa pedra. \\ Porque o único sentido oculto das cousas \\ É elas não terem sentido oculto nenhum, \\ É mais estranho do que todas as estranhezas \\ E do que os sonhos de todos os poetas \\ E os pensamentos de todos os filósofos, \\ Que as cousas sejam realmente o que parecem ser \\ E não haja nada que compreender. \\ Sim, eis o que meus sentidos aprenderam sozinhos:- \\ As cousas não têm significação: têm existência. \\ As cousas são o único sentido oculto das cousas. \\ Alberto Caieiro (heterônimo de Fernando Pessoa)
}

E chego a esta última parte da dissertação com uma certeza. Não havia como denominá-la de "conclusão". Não há como ter plena certeza de se o que escrevi foi de fato conclusivo. Para mim, hoje, não há dúvida: foi conclusivo; amanhã, outro dia. Para quem leu? Como saber? Encerro esta dissertação, então, com algumas considerações finais.

O objetivo traçado foi demonstrar a possibilidade de realizar uma fenomenologia da língua e do signo linguístico. Mas não qualquer fenomenologia; uma fenomenologia nos termos em que Martin Heidegger a definiu. O caminho escolhido para tanto foi encontrar interpretações de caráter fenomenológico em autores que, ao analisarem a língua e o signo linguístico, consciente ou inconscientemente não buscaram interpretá-los e explicá-los fenomenologicamente. $\mathrm{O}$ critério adotado para selecionar tais autores foi apresentar-se em relação próxima com o estruturalismo linguístico ou, basicamente, ter empregado a metodologia estruturalista para analisar a língua e o signo linguístico. Os autores escolhidos foram: Ferdinand de Saussure, Louis Hjelmslev, Roland Barthes, Umberto Eco e Izidoro Blikstein.

O exercício da demonstração da possibilidade de uma fenomenologia da língua e do signo linguístico foi realizado na Parte II desta dissertação. Essa parte da dissertação foi 
composta por cinco capítulos, um para cada dos autores selecionados. Em cada capítulo, segui um mesmo trajeto. Num primeiro momento apresentei uma resenha sobre a análise que cada autor realizou sobre a língua e sobre o signo linguístico a partir da aplicação da metodologia estruturalista. Num segundo momento, após a apresentação da resenha, busquei demonstrar que no interior de cada análise fundada na metodologia estruturalista foi possível encontrar argumentos de natureza fenomenológica; isto é, busquei demonstrar que cada um dos autores, ao realizar uma análise estruturalista, sempre, também e simultaneamente, realizou uma análise acerca do modo de ser da língua e do signo linguístico.

Resumindo o que foi exposto nos cinco capítulos da Parte II. Ferdinand de Saussure identificou que o ser da língua se mostra em si mesmo como a realidade (ser-a-realidade); Hjelmslev identificou que o ser da língua se mostra em si mesmo como o cognoscível, como tudo o que pode ser conhecido (ser-o-cognoscivel); Roland Barthes identificou que o ser da língua, em seu estado usual, se mostra em si mesmo como aprisionamento (ser-aprisionante) e, em seu estado rumorejante, como erotismo (ser-erótico); Umberto Eco identificou que o ser da língua se mostra em si mesmo como o mundo em si, pois, ao implicar a única visão do mundo, acaba por com ele se confundir (ser-o-mundo); e Izidoro Blikstein identificou que o ser da língua se mostra em si mesmo como aprisionamento e iludição (ser-aprisionante e serilusório; ser-sempre-o-mesmo). Essas cinco interpretações, não obstante diferentes, são complementares e capazes de revelar (deixar e fazer ver) o ser da língua em sua quase totalidade (afinal, para confirmar a totalidade seria indispensável a realização efetiva de uma fenomenologia).

E se as interpretações fenomenológicas sobre a língua foram um tanto discrepantes, as interpretações sobre o signo linguístico foram apreciavelmente coincidentes. Os cinco autores identificaram que o ser do signo linguístico se mostra em si mesmo como instrumentalidade (ser-para), como algo que serve para uma finalidade. Diferiram minimamente, contudo, com relação ao usuário do signo enquanto instrumento. Enquanto Saussure, Hjelmslev, Barthes e Blikstein qualificaram o ser-para como ser-para-a-língua (o signo linguístico é usado pela língua para algo), Eco qualificou-o como ser-para-o-falante (os falantes da língua usam seus signos para uma finalidade).

Tudo isso permitiu-me atingir a seguinte conclusão: é sim possível deixar e fazer ver por si mesmo o ser da língua e do signo linguístico, tal como se mostram a partir de si mesmos.

Essa conclusão, contudo, não indica que minha pesquisa necessariamente seguirá esse caminho. Um dia, quem sabe, dedicar-me-ei a uma abordagem especificamente fenomenológica desses dois entes, a língua e o signo linguístico. Por ora, no entanto, há ainda 
muitas dúvidas que preciso solucionar; e há também outros interesses que foram surgindo ao longo da pesquisa. Não terei como fugir, por exemplo, do conceito de existência semiótica. Por outro lado, terei de em algum momento enfrentar a seguinte questão: se a fenomenologia questiona o sentido de ser, não seria ela uma forma de semiótica, uma semiótica do ser?

Enfim, dentre tantas incertezas, permanece a certeza de que minha pesquisa continuará, de um modo ou outro, dentro da linguística e da filosofia - se é que há linguística que não seja filosofia, se é que há filosofia que não seja linguística, se é que há algo que não seja linguística ou filosofia. 


\section{REFERÊNCIAS}

BARTHES, Roland. Crítica e Verdade. 3. ed. - São Paulo: Perspectiva, 1999.

. Elementos de semiologia. - São Paulo: Cultrix, 2012.

. O rumor da língua. - São Paulo: Martins Fontes, 2004.

BENVENISTE, Emile. Problemas de linguística geral - V. 1. - Campinas: Pontes, 2005.

. Problemas de linguística geral - V. 2. - Campinas: Pontes, 2006.

BLIKSTEIN, Izidoro. Kaspar Hauser ou a fabricação da realidade. 2. ed. - São Paulo: Cultrix, 1985.

DICIONÁRIO escolar da língua portuguesa / Academia Brasileira de Letras. 2. ed. - São Paulo:

Companhia Editora Nacional, 2008.

DICIONÁRIO Michaelis On-line. São Paulo: Editora Melhoramentos, 2019. Disponível em: < https://michaelis.uol.com.br>. Acesso em 28 de jul. 2019.

ECO, Umberto. A busca da língua perfeita na cultura europeia. 2. ed. - Bauru: EDUSC, 2002. . A estrutura ausente: introdução à pesquisa semiológica. - São Paulo: Perspectiva, 2013 . As formas do conteúdo. - São Paulo: Perspectiva, 2010.

. Tratado geral de semiótica. - São Paulo: Perspectiva, 2014.

. Viagem na irrealidade cotidiana. - Rio de Janeiro: Nova Fronteira, 1984.

GREIMAS, A. J.; COURTÉS, J. Dicionário de semiótica. 2. ed. 3. reimpressão. - São Paulo: Contexto, 2016.

HEIDEGGER, Martin. A caminho da linguagem. - Petrópolis, RJ: Vozes; Bragança Paulista, SP: Editora Universitária São Francisco, 2003.

. Introdução à filosofia. 2. ed. - São Paulo: Editora WMF Martins Fontes, 2009.

. Ser e tempo. 10. ed. - Petrópolis, RJ: Vozes; Bragança Paulista, SP: Editora

Universitária São Francisco, 2015.

HJELMSLEV, Louis. Ensaios linguísticos. - São Paulo: Perspectiva, 1991.

. Prolegômenos a uma teoria da linguagem. - São Paulo: Perspectiva, 2013.

HOUAISS, Antônio; VILLAR, Mauro de Salles. Dicionário Houaiss da língua portuguesa. 1. ed. - Rio de Janeiro: Objetiva, 2009.

NIETZSCHE, Friedrich. Além do bem e do mal: prelúdio de uma filosofia do futuro. 4. ed. Petrópolis, RJ: Vozes, 2014.

. A gaia ciência. 1. ed. - São Paulo: Companhia das Letras, 2012.

SAUSSURE, Ferdinand. Curso de linguística geral. 28 ed. - São Paulo: Cultrix, 2012A. 
. Escritos de linguística geral. - São Paulo: Cultrix, 2012B.

SEVERINO, Antônio Joaquim. Metodologia do trabalho científico. 23. ed. rev. e atual. - São Paulo: Cortez, 2007.

WITTGENSTEIN, Ludwig. Investigações filosóficas. 9. ed. - Petrópolis, RJ; Vozes; Bragança Paulista, Sp: Editora Universitária São Francisco, 2014. 